\title{
POBLación, uRbanisMo Y ESTRUCTURA POLfTICA DE LAS ALJAMAS JUDÍAS DE ARAGÓN EN EL SIGLO XV 1
}

\author{
por \\ MIGUEL ANGEL MOTIS DOLADER \\ Universidad de Zaragoza
}

RESUMEN: En el presente estudio el autor analiza la dinámica interna de las comunidades judias de Aragón durante el siglo XV desde tres perspectivas: la demografia, el urbanismo y la estructura política. En primer lugar, se abordan los factores que explican la contracción poblacional, entre los que destacan la peste bubónica, los enfrentamiento bélicos con Castilla, las persecuciones de 1391 y las campañas de adoctrinamiento y catequesis forzosa emprendidas por la Iglesia. Se aportan datos cuantitativos sobre las aljamas más importantes, llegando a la conclusión de que en la Corona de Aragón en 1492 vivian unos diez mil ó doce mil judios. En otro epigrafe se estudian los medidas segregacionistas adoptadas en materia urbanistica, las cuales incidirán directamemente en el hábitat judio. Una de las principales aportaciones, en fin, se refiere al examen de la estruc. tura jurídica de las aljamas, con especial énfasis en los órganos de poder y el sistema electoral.

Palabras Clave. España, Aljamas judias Aragón, siglo xv, urbanismo, demografia, estructura política.

ABSTRACT: In this article the author analyses the inner dynamics of the jewish communities in Aragon during the fifteen century from demographic, urban and political perspectives. Firs of alt, we study the chief factors which explain the slope of population, that is, black plague, Castilian wars, 1391 persecutions and ecclesiastical indoctrination. However, in 1492, there were in the Crown of Aragon about ten or twelve thousands jews. In another chapter, we examine segregational measures related to jewish habitat. Lastly, one of the more outstanding purposes deals with juridical structure of aragonese aljamas, with special emphasis in political organs and electoral systems.

KEY wORDS: Spain, jewish Communities Aragon, aljamas, xv century, urbanism, demography, political structure.

Hispennia, LVl/3, núm. 194 (1996) 885-944 


\section{PLANTEAMIENTo ${ }^{2}$}

La historia interna de los judíos de la Corona de Aragón se inaugura, por lo que entraña de cambio estructural, en el año 1391, a propósito de las alteraciones finiseculares que dieron lugar a una auténtica metamorfosis social ${ }^{3}$. Esta convulsiones pueden entenderse como una de las primeras premisas operativas en el proceso secular de la expulsión, cuya materialización requería cuando menos de la confluencia de dos factores: la irreversible debilidad estructural político-institucional y socio-económica de las aljamas, auspi-

I El presente artículo recoge el texto íntegro de la ponencia que, en el marco del International Symposium. Jews and Judeoconverts of Spain at the Time of the Expulsion in 1492, celebrado en New York en el año 1492, defendi con el terna "The XVth Century Jewish Communities in the Crown of Aragon: urbanism, density, economic and social conditions». Por razones de espacio y dada la restringida selección de los intervinientes, sójo apareció una versión parcial bajo el título «Las comunidades judías en la Corona de Aragón en el siglo xv: demografia», en Judios. Sefarditas. Conversos. La expulsión de 1492 y sus consecuencias, Valladolid, Ambito, 1995, págs. 32-46.

El lector observará que no se alude tan a penas a la Corona de Castilla, no sólo por no dilatar demasiado el aparato crítico, sino porque en el indicado Congreso fue defendida otra ponencia relativa a ese territorio. GARCIA CASAR, María Fuencisla, «Las Comunidades judias en la Corona de Castilla al tiempo de la expulsión: densidad geográfica, población», Ibidem, págs. 21-31.

Este artículo deseo dedicario, a mi colega Asunción Blasco, ante sus pertinaces intentos por desautorizar mis publicaciones científicas en torno a la minoría judía en la Edad Media -cuyos motivos últimos tan bien conozco- los cuales estimulan mi sentido del humor, mi piadosa comprensión y mi contrastada discreción.

2 Siglas más utilizadas

A.C.A.

A.D.Z.

A.Dioc.Z.

A.H.P.B.

A.H.P.H.

A.H.P.M.

A.H.P.Sos.

A.H.P.Ta.

A.H.P.Te.

A.H.P.Tu.

A.H.P.Z.

A.H.Prov.Z.

A.M.H.

A.M.J.

A.M.T.

Archivo de la Corona de Aragón.

Archivo de la Diputación Provincial de Zaragoza.

Archivo Diocesano de Zaragoza.

Archivo Histórico de Protocolos de Borja.

Archivo Histórico de Protocolos de Huesca.

Archivo Histórico de Protocolos de Montalbán.

Archivo Histórico de Protocolos de Sos del Rey Católico.

Archivo Histórico de Protocolos de Tarazona.

Archivo Histórico Provincial de Teruel

Archivo Histórico Provincial de Tudela,

Archivo Histórico de Protocolos de Zaragoza.

Archivo Histórico Provincial de Zaragoza.

Archivo Municipal de Huesca.

Archivo Municipal de Jaca.

Archivo Municipal de Teruel.

3 Motis Dolader, Miguel Angel, «Disolución oficial de las aljamas judías del reino de Aragón», on The Generation of the Expulsion, from the rise of the Catholic Monarchs till the expulsion, and its itmediate consequences (in Spain till 1516 and in the Sephardi Dispersion till 1520, Jerusalem, The International Association of Historical Societies for the Study of Jewish History, 1992 (en prensa).

Hixpaniat, LVI/3, nuim. 194 (1996) 885-944 
ciada por los 6 rganos de poder cristianos ${ }^{4}$; y el fortalecimiento de la corriente autoritaria y estatalizadora de la Monarquía católicas.

\section{EFECTIVOS POBLACIONALES: LA DEMOGRAFIA}

La ciencia demográfica, con anterioridad al Concilio de Trento (1563), en que se implanta la obligatoriedad de los Quinque Libri, y la publicación del Ritual Romano (1614), que regulariza el uso de los registros parroquiales, no cuenta con un elenco de fuentes intrínsecas ${ }^{6}$ que permitan un recuento poblacional fidedigno ${ }^{7}$. Pese a esta objeción, no debemos negar cualquier acercamiento preestadístico a la realidad poblacional del Medievo ${ }^{8}$, aunque haya de aplicarse una metodología específica":

4 MOTIS DOLADER, Miguel Angel, «Socio-economical structure of the aljamas of the Aragon Kingdom (1391-1492)m, on The Jews of Spain and the Expulsion of 1492, Los Angeles, University of Southern California, 1992 (en prensa).

5 En un reciente trabajo intenté sistematizar una teoria plurifactorial, cuyo sumario reprodızco: 1. Las minorías confesionales y el «Estado Moderno»,-2. Elementos dinamizadores,- 2.1 Factores seculares (1391-1478).- 2.1.1 Las persecuciones de 1391.— 2.1.2 La «solución total» y los anuzim,-2.1.3 Superioridad dogmática de la «catolicidad».-2.2 Mediatos (1479-1491).-2.2.1 Versión of icial: hermenéutica de la propaganda._ a) Corona de Castilla.- b) Corona de Aragón.2.2.2 El discurso histórico.- 2.2.2.1 Instancia político-ideológica.- a) Unidad dinástica y consolidación territorial: soberanía- b) Pacificación política y confesionalidad del Estado.-c) Ausencia judia en las instancias del poder público.- d) Establecimiento del Tribunal de la Inquisición.e) La jurisdicción delegada de la aljama.-2.2.2.2 Instancia religiosa_- a) Consolidación del arquetipo y la otreidad.-- b) Proselitismo judio y fracaso de la segregación.-c) La percepción conversa del judio como amenaza.-- d) Renovación espiritual y reforma cristiana.- 2.2.2.3 Instancia económico-fiscal.- a) Crisis financiera y déficit presupuestario aljamial. - b) Contracción demográfica.- c) Expansión económica y nuevos agentes.- d) Pérdida de interactividad: medidas reglamentistas.-- 2,2,2.4 Instancia jurídica,- - a) La condición de «no naturales»,- - b) Imputación de herejía como delito punible.- 2.3 Inmediatos (1492).-2.3.1 Psicología de un mito: ritualidad y realidad.-2.3.2 La conquista de Granada.- 2.4 Coyunturales. Cfr. Motis DoLADER, Migue] Angel, "Quiebra de la estructura multiconfesional en la Corona de Aragón y el nacimiento del "Estado Moderno"", en La Corona de Aragón y el Mediterráneo. siglos XV y XVI, Zaragoza, Institución Fernando el Católico, 1992 (en prensa).

6 Motis Dolader, Miguel Angel, «Los judíos en el reino de Aragón: fuentes para su estudio y metodología de investigación», en VII Jornadas de la Investigación Cientifica sobre Fuentes Aragonesas, Zaragoza, 1992, págs. 242-280.

7 No se conservan obituarios [como en la sociedad cristiana vid. FABREGA GRAU, Angel, «El Objtuario de la Catedral de Barcelona en el siglo XIII), Anuario de Estudios Medievales, 18 (1988), págs. 193-215] que se registrarían en los pinkassim de la cofradía de cabbarim, ni actas de circuncisión, matrimonios, etc. No existe tampoco el ministerio sacramental. [SALAS AUSENS, José Antonio, «Los "registros partoquiales" y sus posibilidades como fuentes históricas», En I Jomadas de Metodología de la investigación científica sobre fuentes aragonesas, Zaragoza, 1986, págs. 24 y 37].

8 La historiografia catalana ha avanzado de modo sustantivo [SIMON TARRES, Antoni, "La demografia histórica en Catalunya. Un balance histórico», Boletín de la Asociación de Demografia Histórica, 7 (1989), págs. 37-60], lo mismo que en Francia [BERG, Roger, «Démographie historique du 
1. . Existe un corpus fiscal que ha de ser utilizado con cautela ${ }^{10}$, pues opera sobre categorias tributarias, no convertibles automáticamente,

Judaïsme français", Amitiés France-Israel, 240 (1977), págs. 39-43] o en Italia [BACH], R., DELLA Pergola, S., "Gli ebrei italiani nel quadro della demografia della diaspora», Quaderni Storici, 55 (1984), págs. 155-191; Delia PERGolA, Sergio, «Alcuni aspetti quantitativi della distribuzione del cognome fra gli ebrej in Italian, Anuario di Studi Ebraici, 10 (1984), págs. 65-86; GINATEMPO, María, "Problemi di storia demografica nell'Italia medievale», Ricerche Storiche, 13 (1983), págs. 529-41; HARRIS, A. Ch. "La demografia del Ghetto in Italia (1516-1797 circa)», Rassegna Mensile d'Israel, 33 (1967), págs. 1-48].

La mayoría de los estudios se refieren a época contemporánea o son puntuales: ABERBACH, Moses, «Jewish demography», Jewish Quarterly, 27 (1979), págs. 13-15; GuIKSON, Paul, «Selected bibliography", Jewish population Studies, 14 (1972-80), págs. 121-281; Studies in Jewish Demography, Ed. U. O. Schmelz, P. Glikson. S. J. Gould, New York, Ktav. 1983; Romer OBLATH, S., Huberman, S., «Annotated bibliography on the Jewish family», The Pedagogic Reporter, 28 (1977), págs. 48-55; SCHMEL.Z, U., «The demographic study of the Sephardim in the world», en Actas del Simposio de Estudios Sefardies, 1 (1970), págs. 211-221; SchMEWLZ, U. O., «Dernography», Encyclopaedia Judaica, Jerusalem-New York, Macmillan-Keter, vol. 5, págs. 1493-1521 y RoSENTHAL, E., «Jewish populations in general decennial populations censuses», Jewish Journal of Sociology, 11 (1969), págs. 31-39; Collen, Robert, «Recent trends in Jewish historical demography, Paper in Jewish Demography 1981 n, Proceedings of the Demographic Sessions Held at the 8th World Congress of Jewish Studies. Jerusalem, Ed. U. O. Schmelz, Jerusalem, Hebrew University, Institute of Contemporary Jewry, 1983, Jewish Population Studies, 16, págs. 43-48.

9 BARATier, E., «La démographie médiévale sources et méthodes», Annales de la Faculté des Lettres Sciences Hunaines de Nice, XVII (1972), págs. 9-16. EMANUEL, $\mathrm{H}$., «Some methodological questions in Jewish demography", World Congress of Jewish Studies, 4,2, Jerusalem, 1968, págs. 89-90 y PINI, Antonio Ivan, «Fonti e metodi per la storia demografica íaliana dei secoli XIII-XV», Annali della Facoltà di Lettere e Filosofia. 6 (1985), págs. 95-I 15.

10 Bernal EsTEVEZ, Angel, «La población de Ciudad Rodrigo según el padrón fiscal de 1486", Hispania, 49 (1989), págs. 697-712 y Garcia CASAR, M.`. Fuencisla, El pasado judio de Ciudad Rodrigo, Fontes ludaeorum Regni Castellae, vol. VI, Salamanca, 1992, págs. 72-116, doc. XXVI/1; PITA MERCE, Rodrigo, "Una lista de judios de Monzón en el año 1397), Ilerda. Miscelània Homenatge a Josep Alfons Tarragó i Pleyan, XLIV (1983), págs. 301-303; SEvillano Colom, Francisco, «La demografia de Mallorca a través del impuesto del morabati: siglos xIv, xv y xvl», Boletín de la Sociedad Arqueológica Luliana, XXXII (974), pág. 247 y SANTAMARIA, Alvaro, "Demografia de Mallorca. Análisis del morabetín de 1329n, Ma)urqa, 20 (1980-84), págs. 155-222 [495 fuegos judios y 4.903 cristianos].

En Valencia no se conserva este tipo de documentación. [Hinojosa MonTalvo, José, «En torno a los judios valencianos: la recuperación de una minoría olvidada», Hispania, 175 (1990), pág, 935]. Sólo a través de los Repartiment, donde se consigna cerca de un centenar de beneficiarios hebreos en la capital, hasta fines del siglo Xul se computan 250 nombres judios. Sagunto, Castellón y Játiva, poseerian 50 familias respectivamente. En Valencia — poblada por 15.000 habitantes - supondrían l/5 del total. Burns, R. I., Moros, cristians $i$ jueus en el regne croat de Valencia, Valencia, Tres $\mathrm{i}$ Quatre, 1987, pág. 206.

Vid. etian LADERO QUESADA, Miguel Angel, «Las juderías castellanas según algunos "servicios" fiscales del siglo XV", Sefarad, XXXI (1971), págs. 249-64 y "Los judios castellanos del siglo XV en el atrendatmiento de los impuestos reales», Cuadernos de Historia. Anexos de la Revista Hispania, 6 (1975), págs. 417-39 y SESMA MUÑoz, Angel, «Demografia y sociedad: la población de Monzón en los siglos xill-xv", Honenaje a don José María Lacarra, Pamplona, Anexos "Principe de Viana», XLVII (1986), págs. 687-89.

Hispania. LV]/3, núm. 194 (1996) 885-944 
como son el fuego y el «domus" o la casa ", que admiten distintos índices, a tenor del marco geocronológico y familiar ${ }^{12}$. Además, la población tributaria o "pechera» no abarca todos los segmentos sociales, por la exención de los estamentos privilegiados, la existencia de personas con un nivel de rentas y patrimonio por debajo de la base imponible ${ }^{13}$, las familias francas ${ }^{14}$, la existencia de fraude fiscal o los errores materiales en su elaboración, no siempre subsanados ${ }^{15}$. Destacan las prorratas y los subsidios extraordinarios ${ }^{16}$, entendiéndose que existe proporcionalidad entre los efectivos, sus bienes y la tasa tributada.

"I En Montpellier, por ejemplo, se distingue entre casa propiamente dicha (maison ) y los dos pisos que suelen componerla (appartements), cada uno de ellos habitados por una familia conyugal, cada casa podría contener en torno a las 7-8 personas lo que elevaría la cota teórica de radicación espacial a 350-400 personas. RuseLL, J. C., «L'evolution démographique de Montpellier au Moyen Agen, Annales du Midi, 74 (1962), pág. 348.

Cuando se considera al hombre como miembro de un grupo, se le designa como individuo o cabeza («caput»), que integra el mismo, sin tomar en cuenta si tiene o no capacidad. [GARCía Gallo, Alfonso, "Curso de Historia del Derecho Privado", en Estudios de Historia de Derecho Privado, Sevilla, 1982, págs. 42-43]. En principio, el fuego o el hogar se corresponde con la familia nuclear, estricta, conyugal, que no comprendía más que el padre, la madre y los hijos hasta su matrimonio o emancipación. En otras ocasiones puede corresponderse a una familia ampliada de tipo patriarcal, o a la asociación de dos cuñados, o de dos hermanos, casados ambos, que lo ponen todo en común, su fuerza de trabajo, su riqueza, sus reservas, etc., con el fin de vivir de un mismo fuego en un mismo domicilio. [AA.VV., Historia de la vida privada, De la Europa feudal al Renacimiento, Taurus, Dirección de Phillippe Ariés y Georges Duby, págs. 421 y 424].

12 Muy rara vez existen referencias a la población judia en los fogajes, como sí sucede en los aprobados de coformidad a lo dispuesto por las Cortes de Maella de 1404. LedeSMA Rubio, María Luisa, «Cortes de Maella de 1404», Estudios de Edad Media de la Corona de Aragón, IX (1973), págs. 527-639.

13 Llega en ocasiones al 33\%. SESMA MuÑoz, J. Angel, «Producción para el mercado, comercio y desarrollo mercantil en espacios interiores (1250-1350): el modelo del sur de Aragón», en Europa en los umbrales de la crisis (I250-1350), XXI Semana de Estudios Medievales, Estella '94, Pamplona, 1995, pág. 223.

14 La regulación puede excluir del hecho imponible determinados supuestos, de forma que éste, por voluntad legal no llegue a producirse - no sujección, por no alcanzar el mínimum establecidoo bien impedir que nazca la obligación tributaria - privilegio regio-, aunque el hecho imponible se haya producido -exención-. Cfr. Motis DoLaDER, Miguel Angel, «Régimen físcal de las comunidades judías de Aragón en la Baja Edad Media: la aljama de Huesca en el siglo XIVm, Homenaje a Alfonso García Gallo, Madrid, 1995, págs. 489-580.

15 Usieto ArteTA, Antonio, Los pueblos y los despoblados, Zaragoza, 1984-86, pág. 9.

16 Romano VENTURA, David, «E! reparto del subsidio de 1282 entre las aljamas catalanas», Sefarad, XIll (1953), págs. 73-86 y «Prorrata de los judíos de Jaca de 1377», Sefarad, XLIl (1982), págs. 3-40.; Cantera Burgos, Francisco y Carrete Parrondo, Carlos, «Los repartimientos de Rabi Jaco Aben Nuñes», Sefarad, XXXl (1971), págs. 213-47; SÁnCHEZ MARTiNEZ, Manuel, «Questíe y subsidios en Cataluña durante el primer tercio del siglo XIV", Cuademos de Historia Económica de Cataluña, XVI (1977), págs. 11-54; «La contribución valenciana a la cruzada granadina de Alfonso IV de Aragón (1327-1336", Primer Congreso de Historia del País Valenciano, Valencia, 1981, vol. II, págs, 479-598; «La fiscalidad Catalanoaragonesa y las aljamas de judios en la época 
$22^{\circ}$. La elaboración de listas nominativas a partir de los negocios jurídicos contenidos en los protocolos notariales ${ }^{17}$, presenta resultados superiores a los alcanzado mediante las listas contributivas ${ }^{18}$, sin ocultar que aquéllas presentan algunas deficiencias, como la intervención casi exclusiva del pater familias y la marginalidad de la mujer. Los otorgantes de los instrumentos tienen capacidad de obrar y contratar, por lo que la población reflejada cuenta veinte años -entre catorce y veinte tienen capacidad imperfecta ${ }^{19}$. La asistencia al notario cristiano es masiva, pero existe un sector social que no concurre a las escribanías al no implicarse en el tráfico ${ }^{20}$.

$3 .^{\circ}$. No se podrán sacar conclusiones definitorias hasta que, mediante sistemas prosopográficos o de otra índole ${ }^{2 l}$-capitulaciones matrimo-

de Alfonso IV (1327-1336): Los subsidios extraordinarios", Acta Historica et Archreologica Medievalia, 3 (1982), págs. 93-141 y "La fiscalidad real en Cataluña», Anuario de Estudios Medievales, XXII (1992), págs, 341-376; GUILLERE, Christian, «Les finances royales a la fin du regne d'Alfonso IV el Benigno (1335-1336)», Mélanges de la Casa de Velázquez, XVI1 (1982), págs. 33-69 y "Les finances de la Couronnes d'Aragon au début du XIX ${ }^{e}$ siècle», en Estudios sobre renta, fiscalidad y' finanzas en la Cataluña bajomedieval, Barcelona, 1993, págs. 487-507; BERTRAN RolgE, Prim, «Fiscalidad extraordinaria de las aljamas de judios de la Corona de Aragón (1309-1317)», Sefarad, 52 (1992), págs. 305-321.

17 La propuesta metodológica basada en las listas de contribuyentes, defendida por David ROMANO en «Prorrata de contribuyentes judios de Jaca en 1377», págs. 3-40, es insatisfactoria aunque apreciable.

18 Motis Dolader, Miguel Angel, Los judios de Jaca en el siglo Xv, Zaragoza, 1996 (en prensa).

${ }_{19} \mathrm{Cfr}$. la glosa del fuero «Ut minor viginti annorum», otorgado en 1381, en ORTEGA SAN lNigo, Julio, «Ut minor XX annorum», en Segunda Semana de Derecho Aragonés, Jaca, 1943, págs. 13339 y SANCho Rebullida, F. A., «La edad en Derecho Aragonés», en Homenaje a J. Moneva Pujol, Zaragoza, 1954, págs. 341-9l. En el terreno específicamente hebreo: Lebendiger, I., "The minor in Jewish law», Studies in Jewish Jurisprudence, ed. by GerSHFIELD, E. M., New York, 1971, págs. 91180 y Motis DolADER, Miguel Angel, «Consuetudine regni non habemus patriam potestatem. Un supuesto de tutela y curatela en la juderia de Daroca en el siglo xv», Ius Fugit. Revista Interdisciplinar de Estudios Histórico-Jurídicos, I (1992), págs. 79-138.

20 Máxime cuando triunfa el acto documentado, bajo la influencia del / $u s$ commune y la decretalistica como elemento sustancial de prueba, lo que se produce en el siglo XV. MartínEz Gión, José, «La prueba judicial en el Derecho territorial de Navarra y Aragón durante la Baja Edad Media", Anuario de Historia del Derecho Español, 31 (1961), pág. 28 y MALDONADO Y FERNÁNDEZ DEL TORCO, José, «Lineas de influencia canónica en la historia del proceso español», Anuario de Historia del Derecho Español, XXIII (1953), págs. 476-77.

21 Existen otros medios secundarios, menos fjables, pero que, careciendo de los anteriores componentes, pueden ser orientativos, como son las cifras inducidas por consumo alimentario, esencialmente el vino y la carne. [MOTIS DOLADER, Miguel Angel, «Régimen alimentario de las comunidades judias y judeoconversas en La Corona de Aragón en la Edad Media», Ir. Colloqui d'Història de l'alimentació a la Corona d'Aragó. Edat Mitjana, Lleida, 1995, págs. 205-362] o la distribución y número de asientos existentes en las sinagogas [MOTIS DOLADER, Miguel Angei, "Reflexiones en torno a las sinagogas de la juơeria de Jaca en la Edad media» Aragón en la Edad Media. Homenaje a la Dra. María Luisa Ledesma Rubio, Zaragoza, 1993, págs. 64 !-660].

Hixpanit. LVI/3, núm. 194 (1996) 885-944 
niales, testamentifacciones ${ }^{22}$, etc.- se realice un estudio de la estructura familiar ${ }^{23}$.

\subsection{Factores de la crisis demográfica (1391-1414)}

A fines del siglo xrv se concitan una serie de vectores que asfixiarán el crecimiento vegetativo de sus comunidades, poniendo en peligro el relevo generacional, lo que engendrará una profunda decadencia, pese a las disposiciones adoptadas por Pedro IV para paliarla ${ }^{24}$. Estos elementos se articulan en tres niveles: la peste negra (1348) ${ }^{25}$, la guerra con Castilla (1356-1369), y las persecuciones de 1391. Pese a que los reinos de la Corona de Aragón - hasta esta centuria - constituyen uno de los territorios más poblados por judíos en el Occidente europeo, nunca se situaron por encima del $3 \%{ }^{26}$.

22 La transmisión mortis causa es un medio de reproducción del sistema social y el modo en el que se estructuran las relaciones interpersonales. ANDERSON, Michael, Aproximaciones a la historia de la familia occidental (1500-19/4), Madrid, Siglo XXI de España Editores, S. A., 1988, pág. 75 \& Gunzererg I MoLL, Jordi, «Testamentos del siglo XIv del Archivo Histórico de Protocolos de Barcelona y su aplicación a la demografia histórica. Estudio archivístico-metodológico", Acta Histórica et Archaeologica Mediaevalia, 10 (1989), págs. 89-98.

${ }_{23}$ DASHEFSKY, Atnold \& IRvingS M. Levine, «The Jewish Family; continuity and changem, en Families and Religions, Conflict and Chage in Modern Society, Ed. William V. D'Antonio, Beverlly Hills, CA, Sagem 1983, págs. 163-190; GolTEıN, Shelomo Dov, "The Jewish family in the days of Moses Maimonides», Conservative Judaism, 29 (3974), págs. 25-35; «Parents and children; a Geniza study on the medieval Jewish family», Gratz College Annual of Jewish Studies, 4 (1975), págs. 47-68 y «The Jewish family of the high Middle Ages as reveafed by documents of the Cairo Geniza», Gli ebrei nell'alto medioevo, Setimane di studio del Centro italiano di Siudi sull-Alto Medioevo, XXVI, Spoleto, I (1980) págs. 713-33; SCHNUR, Hary C., "Jüdische Ehe und Familie im Mittelalten", Mediaevalia Lovaniensia, Series [, 8 (1981), págs. 88-10! y Motı DOLADER, Miguel Angel, «Socio-economical Structure of the Aljamas of the Aragon Kingdom (139l-1492)», op. cit.

24 Motis Dolader, Miguel Angel, Los judíos de la Corona de Aragón en la Edad Media (1/341492), Madrid, Universidad Nacional a Distancia, Departamento de Historia Medieval y Moderna y Fundación Amigos de Sefarad, 1992 (en prensa).

25 Las juderías de Jaca -incinerada y con un elevado número de víctimas-- y Montclús extinguida - padecieron en 1320 los efectos de los pastorelli. Motis DOLADER, Miguel Angel y GuTwIRTH, Eleazar, «Los judíos de Jaca en la época de la Disputa de Tortosa (1410-20)», Anuario de Estudios Medievales (en prensa); MIRET Y SANS, Joaquín, «Le massacre des Juifs de Montclus en 1320. Episode de l'entrée des Pastoreaux dans l'Aragon", Revue des Etudes Juives, 53 (1907), págs. 255-266 y MASIA DE ROS, Angeles, «Aportación al estudio de los "Pastorelios" en la Corona de Aragón», Homenaje a Millás Vallicrosa, vol. Il (1956), págs. 9-30.

26 Los parámetros máximos para la población hebrea en Cataluña dependen de la categoría del municipio: su peso específico es casi nulo en los núcleos rurales; no superan el $2 \%$ en las villas inferiores a 500 habitantes, considerando descabellado, por último, que alcanzaran más del $7 \%$ en las seis ciudades más importantes. Desde el siglo IX hasta su extinción prácticamente en tođas las localidades urbanas se documenta una cierta entidad presencial — siquiera testimonial- de judios. Esto, que es muy cierto y cobra especial vigencia también en el reino aragonés no lo es tanto para el valenciano. En la segunda mitad del siglo XIV, con anterioridad a las persecuciones, en Cataluña vivian 


\subsubsection{Epidémicos: la peste bubónica ${ }^{27}$}

La peste incrementó la tasa de mortalidad ${ }^{28}$, redujo el coeficiente de fertilidad y nupcialidad ${ }^{29}$, y debilitó las estructuras familiares -el foco principal se declaró en $1348{ }^{30}$, reactivándose en 1362 y en $1389^{31}$, no abandonando Occidente, en su patología bubónico-pulmonar, hasta finales del siglo $\mathrm{XV}^{32}$ lo que se tradujo en la ruptura de los eslabones sucesorios, exigiendo una regulación flexible de la abintestación ${ }^{33}$.

La peste produjo un profundo déficit demográfico ${ }^{34}$; Zaragoza redujo su población judía a un quinto, debiendo ampliar su cernenterio ${ }^{35}$-la satura-

entre 10.000 y 12.000 judios y en toda la Corona 30.000 . [R]ERA ! SANS, Jaume, «La Catalunya jueva del segle XIV", L'Avenç, 25 (1980), págs. 205-7] Otros historiadores sitúan el coeficiente a un 7\%. DUfourq, Charles-Emmanuel y GauTier-DalCHE, Jean, Histoire économique et sociale de l'Espagne Chrétienne au Moyen Age, Paris, 1977, pág. 156.

${ }_{27}$ GoTtFrIed, R. S., The Black Death: natural and human disaster in Medieval Europe, New York and London, 1983; ANDENMATTEN, Bernard y MOREROD, Jean-Daniel, «La peste à Lausanne au XIV ${ }^{\mathrm{e}}$ siècle $(1348 / 9,1360)$, Etudes de Lettres, 2-3 (1987), págs. 19.49 y SHIRK, Melanie V., «The black death in Aragon, 1348-1351», Journal of Medieval History, 7 (1981), págs. 357-367.

28 BENEDICTOW, Ole Jorgen, «Some social and medical factors which affect the reliability of statistical data on plague epidemics», Middelalderforum - Forum Mediaevale, 11 (1985), págs. 18293 y RaHE, Thomas, «Demographische und geistig-soziale Auswirkungen der Pest von 1348-1350», Geschichte in Wissenschaft und Unterricht, 35 (1984), págs. 125-144.

29 GeLIs, Jacques, Fertility, Pregnancy and Birth in Early Moderna Europe, Londres, 1991 \& Famiglia e la vila quotidiana in Europa dal ' 400 al '600. Fonti e problemi. Ati del Convegno Internazionale, Milano, 1986.

30 Por estas fechas se desatan movimientos antijudios. BREUER, Mordechai, «The Black Death and antisemitism), Antisemitism through the Ages, Ed. Shmuel Almog, Oxford, Pergamon Press. 1988, págs. 139-51 y LANDAU, L., «La condition des Juifs au Moyen Age; le massacre de la Saint Valentin (Strasbourg, 14 février 1349)», Recontre Chrétiens et Juifs, 6 (1972), págs. 251-57.

31 MoTrs Dolader, Miguel Angel, Los judios en Aragón en la Edad Media (siglos XIII-XV), Zaragoza, Caja de Ahorros de la Inmaculada, Colección Mariano de Pano, vol. 5, Zaragoza, 1990, págs. 48-50.

32 En Bohemia, por ejemplo, se declaró una cruenta plaga en 1380. MAUR, Eduard, «Moorová epidemie roku v Cechach», Historická demografie, 10 (1986), págs. 37-71.

33 Careciendo de herederos legitimos los judios proceden a una declaración forzosa de legitimarios para las transmisiones patrimoniales y el pago de las obligaciones fiscales. LÓPEZ DE MENESEs, A., «Documentos acerca de la peste negra en los dominios de la Corona de Aragón», Estudios de Edad Media de la Corona de Aragón. VI (1956), doc. 31.

34 Azerián Avengoyos, en nombre de su hijo, «lacrimabili», suplicaba que le fuera levantado el arresto y la fianza impuesta de 250 florines por Felipe d'Urries, ya que había marchado a la judería de Ayerbe por la elevada mortalidad que se había declarado en Jaca. A.C.A., Real Cancillería, Reg. 2361 , fo! $17 \mathrm{v}$.

35 Motss Dolader, Miguel Angel, «El cementerio judio de Zaragoza», en Las necrópolis de Zaragoza, Zaragoza, Excelentísimo Ayuntamiento de Zaragoza, Cuadernos de Zaragoza, núm. 63 , 1991, págs. 67-84.

Hispania, LV]/3, núm. 194 (1996) 885-944 
ción de otros hizo necesaria la utilización de los próximos a las juderías ${ }^{36}$-; las consecuencias no fueron más benignas en otras latitudes ${ }^{37}$. Sus efectos no se dejaron sentir con la misma intensidad, especialmente donde se estaba produciendo un cambio económico estructural, en que la recuperación se inició seguidamente ${ }^{38}$. No nos consta que llegaran a desaparecer juderías de entidad. Se multiplican las solicitudes de moratorias en el pago de impuestos "cum occasione vehementis epidemie et mortalitatis, qui in ipsa aliama invaluit hiis diebus" ${ }^{39}$, y se crean tasas extraordinarias ${ }^{40}$ y mecanismos que garantizan el pago de las pechas ${ }^{41}$.

\subsubsection{Los episodios bélicos; la guerra con Castilla ${ }^{42}$}

A lo largo del último tercio del siglo XIV, la frontera occidental de Aragón y el flanco sur de la Corona - Valencia-, padecieron las campañas punitivas

36 En el cementerio de Gerona se consintió cautelarmente el sepelio de los judios de Figueras, aunque ignoramos si se llegó a cumplimentar. REGNE, Jean, History of the Jews in Aragon. Regesta and Documents (1213-1327), Jerusalem, 1978, doc. 389. Cit. también Romano Ventura, David, «Fossars jueus catalans», Acta Historica et Archceologica Medicevalia, 14-15 (1993-94), pág. 300.

37 En 1348 en Tárrega fallecieron 300 jứíos, más de un tercio de la población total —en un censo de 1359 un total de 195 fuegos se especula una implantación de 350 hebreos-. 'Emeq haBakha de Yosef ha-Kohen, Crónica hebrea del siglo xVl, Traducida y anotada por LEÓN TELLo, Pilar, C.S.I.C., Instituto "Benito Arias Montano», Madrid, 1964 y HACOHEN, Yosef, El valle del llanto (Emeq ha-Bakha), Crónica Hebrea del siglo XVI, Introducción, traducciớn y notas por Piłar León Tello, Barcelona, Riopiedras, 1989 , pág. 83.

38 En la Comunidad de Teruel y Albarracin, según los monedajes de mediados del siglo XIV y posteriores -que arrojan unos 17.000 fuegos familiares 045.000 personas-, la tasa de mortalidad varió entre un $8 \%$ y $30 \%$. SeSMA MuÑoz, Angel, «La población aragonesa ante la crisis demográfica del siglo XIv. El caso de la comunidad de Teruel (1342-1385), Estudios de Historia Medieval en Homenaje a Luis Suarez Fermández, Valadolid, 1991, págs. 457-72.

39 Motis Dolader, Miguel Angel, «Judios y judeoconversos de la Raya Occidental del reino de Aragón», en Borja y la Raya Occidental en Aragón. Ponencias, Zaragoza, Institución Fernando el Católico, 1992, pág. 65

40 Pedro IV, el 5 de febrero de 1351, para paliar las cargas tributarias padecidas por la ajjama de Borja, a consecuencia de las malas cosechas y de la peste negra, que la habían colocado «ad irreparabilem destruccionem deductas, legisla que durante 3 años sus adelantados elijan seis ancianos, dos de cada uno de los tres estratos sociales, para que repartan un impuesto mercantil, Motis DoLADER, Miguel Angel, Los judíos de Borja en el siglo Xv, Borja, 1987, pág. 25.

41 LÓPEZ DE MENESES, A., «Documentos acerca de la peste negra en los dominios de la Corona de Aragón», docs. 31 y 100.

42 Existe el probiema concomitante de las bandosidades señoriales que llegaron a constituir una amenaza para sus habitantes. En 1396 pactan unas capitulaciones los infanzones, hombres de condición y vecinos de Borja, donde se contempla que el juez de la villa custodiaría el castillo y la juderia para la reina doña Violante y garantizaria a tos vecinos que pudieran guarecerse en su recinto en caso de peligro; no iría en contra del lugarteniente del alcaide, el cual se compromete a la salvaguardia del castillo y la judería; no colocaría a más de 20 personas como defensores, las cuales deberían ser naturales del Reino y no pertenecer a bandosidad alguna; el lugarteniente no inflingiría daño 
de Pedro I de Castilla ${ }^{43}$. La magnitud de las operaciones pierde intensidad conforme nos alejamos de la línea fronteriza, no cobrándose víctimas en el condado catalán ${ }^{44}$.

Las tropas castellanas golpearon con contundencia en las villas y ciudades limítrofes de Tarazona ${ }^{45}$, Borja ${ }^{46}$, Cariñena, Calatayud ${ }^{47}$ y Teruel, donde no encontró una gran oposición; sólo Daroca resistió la gran ofensiva de 1363, conjurando la ocupación del Reino ${ }^{48}$. Las muertes se produjeron no tanto por las lides militares sino por la devastación de los centros urbanos, como la sufrida por Tarazona y Calatayud -entre 1357-61- arrasadas por el fuego y los bombardeos de catapultas. El restablecimiento de las funciones urbanas se inicia tras el magnicidio del soberano castellano; las primeras concesiones para reedificar las sinagogas - - dirutam et destructam ex eo quod in occupacione dicte civitatis»-., datan del trienio $1368-1370^{49}$.

al concejo, dejaría expedito el paso a la judería y no consentiría el internamiento de compañías extrañas en dicho bartio; el concejo, por su parte, si así lo estima oportuno, podría colocar guardas adicionales en la judería, pero a las órdenes del aicaide. A.H.P.Ta, Protocolo de Bernart de Castellblanch, 1396, fols. 209-213v.

43 GutiérRez de VelasCo, A., "La financiación aragonesa de la Guerra de los dos Pedros», Hispania, XIX (1959), págs. 3-43; «La conquista de Tarazona en la Guerra de los Dos Pedros (1357)", Revista de Historia Jerónimo Zurita, 10-11 (1960), págs. 69-98; "La fortalezas aragonesas ante la gran ofensiva castellana», Revista de Historia Jerónimo Zurita, 12-13 (1961), págs. 7 39 y «La contraofensiva aragonesa en la Guerra de los Dos Pedros», Revisła de Historia Jerónimo Zurita, 14-15 (1963), págs, 7-30.

44 Los judios financian un cuerpo expedicionario de setecientos caballeros. De un total de 38.500 sueldos, recayeron sobre las arcas de las minorías de las localidades fronterizas (Calatayud, Uncastillo, Borja, Ejea, Tauste y Daroca), 34.200 sueldos. GutıÉrReZ de VelASCO, A., «La financiación aragonesa de la Guerra de los dos Pedros», pág. 7.

45 En 1367, poco antes de trasladarse a las Cortes de Zaragoza a solicitar subsidios [ZuRITA, J., Anales de la Corona de Aragón, Zaragoza, 1562-1580, Edic. A. Canellas, Zaragoza, Institución Fernando el Católico, 1978, pág. 557, consultó a los brazos la conveniencia de đefenderla o derribarla. Sesma Muñoz, A. y Sarasa SÁnChez, E., Cortes del reino de Aragón (1357-145I). Extractos y Fragmentos de procesos desaparecidos, Valencia, Editorial Anúbar, 1976, pág. 64.

El desmantelamiento de la judería calcinada no se consumó gracias al decidido empeño del infante Juan y del baile y merino de la plaza, diez años después del último episodio de armas. A.H.P.Ta, Protocolo de Bernart de Castellblanch, 1391, fol. 122.

46 A.H.P.Ta, Protocolo de Miguel Pérez Romeu, 1365, s.f.s.d.

47 El monarca, el 20 de julio de 1371, tras certificar que «aljama Calatayubii propter Castelje ad destructionis articulum fere deducti estis», le concede la equiparación jurídica con los cristianos. A.C.A., Real Cancillería, Reg. 921, fol. 33.

${ }_{48}$ Corral Lafuente, José Luis, «La frontera entre Aragón y Castilla en la región del Moncayo en la Edad Media», en Borja y la Raya Occidental en Aragón. Ponencias, Zaragoza, Institución Fernando el Católico, 1992, pág. 199.

49 Motis Dolader, Miguel Angel y AinaGa ANDRÉs, María Teresa, «Patrimonio urbanístico ajjamial de la judería de Tarazona (Zaragoza); las sinagogas, la necrópolis y las carnicerías", Revista de Historia Jerónimo Zurita, 56 (1987), docs. 1, 2 y 3, págs. 119-121.

Hispania, LV1/3, núm. 194 (1996) 885-944 


\subsubsection{Las persecuciones de 1391}

En el crepúsculo del siglo XIV se desataron corrientes latentes, en un contexto de crisis y mutaciones, que produjeron graves brotes de violencia ${ }^{50}$ -se atenta por vez primera con total impunidad contra el supremo bien jurídico de la vida ${ }^{51}$-, donde entiendo que se produce el tránsito del antijudaísmo teórico al práctico. Señalo, atendiendo a su sintomatología, dos áreas.

\section{a) Reino de Aragón}

La presencia de los monarcas en Zaragoza - la cual pasa de tener 313 casas judías en 1369, a 347 en 1406, con un incremento relativo del 11\% 52 -, dispuestos a defender a sus "cofres» ${ }^{53}$ por motivos fiscales ${ }^{54}$, la dignidad de la institución monárquica y el orden público, fue un elemento de estabilidad, amén de la actuación de Hasday Cresquas para cohesionarla.

Es destacable el clima de paz social que se respira allí donde la guerra había causado más estragos y donde los efectivos humanos eran imprescindibles en la reconstrucción económica. Las alteraciones se registran, sin pérdidas humanas reseñables, en los dominios orientales y meridionales Aínsa, Barbastro, Jaca, Huesca, Monzón, Tamarite, Albarracín y Teruel-, más capilares a los eventos catalanes y valencianos:

Aunque no tuvo una influencia notable sobre el substratum demográfico, sí configuró un cambio radical en las relaciones intercomunitarias al evolucionar de la "convivencia" a la "coexistencia". Entre las corrientes migratorias destaca la generada rumbo a Navarra, participada por las clases dirigentes y los estratos económicos más activos - compensada con la inmigración de judíos huidos de los territorios costeros de la Corona ${ }^{55}$, favorecida por la cercanía y

50 MACKAY, A. y MCKENDRICK, G., «La semiología de los ritos de violencia: sociedad y poder en la Corona de Castilla», En la España Medieval, 11 (1988), págs. 153-163.

51 Motis DOLADER, Miguel Angel, «Quiebra de la estructura multiconfesional en la Corona de Aragón y el nacimiento del "Estado Moderno"

52 Hemos de incluir en nuestro cómputo las familias francás de los Alazar y la Cavallería que habitaban entre quince y treinta inmuebles.

53 La colectividad judia, en cuanto "coffre e tresor del senyor rey" generan unos ingresos tipjficados dentro de la categoria patrimonial. SÁnChez MARTíneZ, Manuel, «La evolución de la fiscalidad regia en los paises de la Corona de Aragón (c. 1280-1356)», en Europa en los Umbrales de la crisis (I250-1350), XXI Semana de Estudios Medievales, Estella '94, pág. 408.

54 Motss DoLADER, Miguel Angel, «Contexto juridico de la expulsión; el problema del status y de la naturalezan, Miscelánea de Estudios Arabes y Hebraicos (en prensa).

ss En Valencia, por su condición de puerto de mar y centro mercantil, siempre se habían dado cita judios de otras procedencias. PiLes Ros, Leopoldo, uJudios extranjeros en la Valencia del siglo XV", Sefarad, VIl (1947), págs. 151-156 \& Hinojosa MonTalvo, José, «Judíos portugueses en Valencia a fines de la Edad Media», Revista de Ciências Históricas, X (1995), págs. 221-234. 
los lazos familiares ${ }^{56}$. Se advierte un retroceso en la actividad crediticia y una disminución del mercado de capitales - créditos de consumo-, así como cambios en la cúpula dirigente y en el sistema electoral ${ }^{57}$.

\section{b) Reinos de Valencia y Mallorca y principado de Cataluña ${ }^{58}$}

El panorama se presenta convulso, al producirse la extinción de grandes aljamas que habían desplegado un decisivo liderazgo --el cual será heredado por Zaragoza - y una reorganización demográfica del espacio.

En Valencia esta redistribución de las aljamas convulsiona la cartografía uniforme de los siglos XIII y XIV ${ }^{59}$, en especial la infraestructura costera de las villas de realengo, replegadas ahora a la zona central del reino, entre Castellón de la Plana ${ }^{60}$ y Játiva ${ }^{61}$, con su epicentro en Sagunto; desaparecen las aljamas de la zona norte y en el sur persiste la gens residual de Orihuela ${ }^{62}$.

56 Leror, Beátrice, «Les relations des juifs de Navarre et des juifs de la Couronne d'Aragon», en Ir. Colloqui d'Historia dels Jueus a la Corona d'Aragó, Lleida, 1991, págs. 157-166.

57 Cuella EsTeBan, Ovidio, «Situación social y politica de la comunidad de Calatayud en el tránsito del siglo XJV al XV), Primer Encuentro de Estudios Bilbilitanos, vol. II, Zaragoza, 1979, págs. 14148; LEROY, Beatrice, «Ruina y reconstrucción. Los campos y las ciudades de Navarra en la segunda mitad del siglo XIV', Hispania, XLIV (1984), págs. 245-46. CaBanes Pecourt, M.' Desamparados, "Cartas de población del dominio verolense», Aragón en la Edad Media. Estudios de Economía y sociedad, VI (1984), págs. 101-103; MotIS DOLADER, Miguel Angel, «Convulsiones finiseculares y conflictividad social: la aljama judia de Tarazona y los pogroms de 1391», I Jornadas Nacionales sobre la Conarca del Moncayo, "Ciencias Sociales», Tarazona, 1989, vol. I, págs. 191-224.

58 Sobre el modo como se produjeron los tumultos podemos señalar algunos rasgos: a) la ira popular no apuntaba directamente a la muerte de los judios, sino a su supresión por la muerte o por el bautismo; b) el ataque indiscriminado a todos los que intentaban defenderlos; c) el sintomático asalto a la morería después de operada la destrucción de la judería; y d) la personal visión providencialista de los hechos. RIERA i SANS, Jaume, «Los tumultos contra las juderías de la Corona de Aragón en 1391", Cuadernos de Historia. Anexos de la Revista Hispania, 8 (1977), págs. 213-225.

59 A fines del siglo xII! y principios del XIV, se contabilizan 23 localidades en el reino de Valencia, que se extienden en un radio de acción que abarca desde Morella hasta Alcoy. Las comarcas alicantinas integradas en el reino de Murcia sólo registraron cuatro asentamientos de importancia: Orihuela, Alicante, Elche y Elda. La génesis de estas implantaciones poblacionales suelen obedecer a motivos estratégicos y económicos, sin olvidar la evolución de la contienda con el musulmán. En 1414 existe una presencia testimonial judia en Callosa d'En Sarrià, en Aspe en 1491 o en Cocentaina. Segorbe reunia ocho fuegos en 1421, que no llegaban ni al $2 \%$ de la población. Orihuela acredita un máximo de 38 casas en el siglo xv. Hinojosa MONTALVo, José, «En torno a los judios valencianos: la recuperación de una minoría olvidadas, pág. 93].

60 Castellón de la Plana, se encuentra al borde del colapso en 1400 , con sólo cinco casas, a causa de las conversiones masivas de la década anterior. MAGDALENA NOM DE DEU, José Ramón, "Notas sobre conversos castellonenses en 1391", Boletin de la Sociedad Castellonense de Cultura, LIII (1977), págs. 161-170.

6) Ventura, Agusti, «Possible localització de la jueria o call de Xátiva», Xátiva, fira d'agost, Játiva, 1979, págs. 29-36.

62 VILAR, Juan Bautista, «La judería medieval de Orihuela (Alicante)», Boletín de la Asociación Española de Orientalistas, XIII (1977), págs. 175-186 \& Hinojosa MonTalvo, J. y Barrio Barrio, J. A., «Las sisas en la Gobernación de Orihuela durante la Baja Edad Media», Anuario de Estudios Medievales, XXII (1992), págs. 535-580.

Hispania, LV1/3, nủm. 194 (I996) 885-944 
En la ciudad de Valencia permanecieron algún tiempo unos doscientos judíos - conviviendo con los conversos- de los 2.500-3.000 judíos (10\%) que pudo llegar a contar en momentos de esplendor ${ }^{63}$. La peligrosidad de esta promiscuidad aconsejo su traslado al castillo de Murviedro, de donde no retornarán; años después encontramos una exigua comunidad de treinta personas que atravesaba una grave crisis económica, sobrellevando la obligación de alimentar los leones que el monarca tenía en el Real ${ }^{64}$.

El principado de Cataluña fue uno de los más damnificados - llegó a contar con 9.000 almas-, pasando de ser un territorio densamente poblado a poseer una demografía residual, acápite tras la disolución de la aljama barcelonesa ${ }^{65}$. Parecido acontecer se produce en el territorio insular ${ }^{66}$.

63 Hinojosa Montalvo, José, «La comunidad hebrea en Valencia; del esplendor a la nada (1377-1391), Saitabi, 31 (1981), pág. 57.

64 Sobre el contexto anterior a los asaltos de 1391: GARcía, Angelina, «Médicos judios en la Valencia del siglo XIV", Estudios dedicados a Juan Peset Aleixandre, Valencia, Universidad, 1982, vol. Il, págs. 85-96 y «El préstamo judío en la Huerta de Valencia durante el siglo XIV», Annals, 1982, págs. 183-223; Hinotosa MonTALVo, José, «Los judios valencianos en la época de las Vísperas sicilianas (1283-1336)", XI Congreso de Historia de la Corona de Aragón, Palermo, 1984, vol. III, págs. 195-219; MAGDALENA NOM DE DEU, Ricardo, «Aspectes de la vida dels jueus valencians a la llum d'unes fonts hebraiqques: les respostes de Rabi Yishaq Ben Seset Perfet (segona meitat del segle XIV)», Afers, 7 (1988-89), págs. 189-205; «Delitos y "calonies" de los judios valencianos en la seguna mitad del siglo XIV (1351-1384)», Anuario de Filología, II (1970), págs. 21 1- y «Un zoco judaico en la Valencia medieval (1351-1389)», Sefarad, XXXIX (1979), págs. 309-332;

65 En el siglo xiv, la aljama de Barcelona era tan grande como la de Valencia, con unas mil familias; mientras que ésta última contaba en 1359 con 7.651 fuegos (13,3\%); la ciudad condal según los padrones de 1383 y 1392 - poseía 171 cabezas de familias antes de su conversión masiva, cuando la ciudad cuenta con 4.000 almas. Un año más tarde de los pogroms 125 pater familias conversos designan un procurador encargado de recuperar los bienes que les habian sido decomisados.

A cierta distancia se encuentra Gerona con unas 1.000 personas - cuenta con 150 fuegos entre 1320-30, algo menos del 10\% del total; después de la peste, en 1360 , se identifican 130 personas, mientras que la población cristiana se sitúa en 1850 fuegos, lo que la coloca en el 7\%-; Lérida contaba con medio millar - de los cuales, en 1391, fallecieron un mínimo de 78 juđíos-; Tortosa y Cervera tres centenares. Entre 100 y 50: Balaguer, Besalú, Solsona y Tarragona. Gravitan sobre el centenar: Agramunt, Castelló d'Empúries, Montblanc, Santa Coloma de Queralt y Tảrrega. Bellpuig de Ulgell y Villafranca frisaban los 80; Camarasa, Cardona, Valls -de 18 familias en 1277 pasará a 58 en 1342 - y Manresa - según algunos autores, en el último tercio del siglo xIIl, contaba con más de 200 fuegos, con 1/5 de la población-, 60; Falset, Torroella de Montgrí y la Seu d'Urgell, 40. Finalmente Berga, Castellfollit de Riubregós, Verdú y Vic no rebasaban los 30.

A través de la actividad crediticia se estima: Castellón de Ampurias entre 75 y 80; Besalú y Banyolas entre 30 y 40 , La Bisbal (20-25) y Torroella de Montgrí (12). Santa Coloma de Queralt fue cedida al poder señorial sin perder sus privilegios sucesorios ni del libre ejercicio profesional. GulLLERE, Christian, «Juifs et Chrétiens à Gerone au XIvंme siècle», en Jornades d'Història dels Jueus a Catalunya, Girona, Ajuntament, 1990, págs. 45-65.

${ }_{66} \mathrm{La}$ isla de Mallorca, poblada a principios del siglo XIV con 50.000 almas, registra 3.000 judios (6\%). Más del $90 \%$ se concentraba en Palma, si nos basamos en una lista de cabezas de familia judias de 1339 , donde nomina 250 unidades familiares en la ciudad, y tan sólo 26 fuera de la capital. Se conserva otra tabulación de 1343 con los contribuyentes de Palma del morabotin del que 
A título meramente ilustrativo, podemos aportar unos datos a quo en torno a la mortandad: Valencia (230 ${ }^{67}$ ), Mallorca (300), Barcelona (300-400), Lérida $(80)$, etc. ${ }^{68}$ Una consecuencia concomitante fue la dispersión de la población y su ruralización, abandonando las grandes ciudades y creando nuevas comunidades; las revueltas antijudías siempre habían tenido un neto componente urbano, con lo que el hábitat rural confería una sensación de mayor seguridad.

\subsection{El siglo xv: conversiones masivas y estabilización}

Comienza la centuria con un documento de carácter fiscal muy operativo. El 22 de enero de 1405, con motivo de las medidas adoptadas en las Cortes de Maella para aliviar el déficit comercial exterior y los censales que pesaban sobre el General del Reino, se realiza un fogaje general ${ }^{69}$, que determina 42.683 hogares ${ }^{70}$. Sin embargo, hemos de adoptar estas cifras con cautela en 1364 se estiman 34.200 casas $^{71}$, teniendo en cuenta que, debido a la despoblación que se produce en algunos lugares, el hambre, las campañas bélicas y las epidemias, en las Cortes de Valderrobres de 1429 son revisados a la baja ${ }^{72}$. En general, podríamos aventurar una cifra total -incluyendo cristianos, mudéjares y judíos - próxima a los 200.00 habitantes, sin que el conjunto de los territorios de la Corona de Aragón, además de Mallorca, sobrepasara el

habían sido dispensados determinados judíos por la posesión de un privilegio real o por tener unos bienes por debajo de los minimos establecidos. Se censan 335 cabezas de familia sobre un total de 4.124. Con posterioridad a la peste negra la misma fuente cuenta 516 cabezas de familia (el $12-12 \%$ de los sujetos tributarios). QUADRADO, José María, «La juderia de la capital de Malkorca en 1391 », Boletín de la Real Academia de la Historia, IX (1886), págs. 294-312.

${ }_{67}$ Murieron un centenar de judios en el tumulto, y sobrevivieron doscientos agosto; su población total no superaría los 500-600 efectivos [Valencia en la época de Juan l, Valencia, 1974, pág. 74]. Esta estimación es incrementada por J. Hinojosa Montalvo a 2400 [«La comunidad hebrea en Valencia: del esplendor a la nada (1377-1391)», pág. 55]

68 Motis DOLADER, Miguel Angel, Los judios de la Corona de Aragón en la Edad Media (1I341492), op. cit.

69 Como punto de partida sabemos que los brazos de la iglesia, la nobleza y las universidades -en esta última categoria se incluirían los judios - tributarían por cada fuego o casa con 12 sueldos, mientras que si pertenecían a la caballería su cuota se reducía a 7 sueldos. A.H.P.Z., Fogajes de las Cortes de Maella, 1405, fol. 87.

Los judíos, en cuanto sujetos tributarios, contribuyen desde la segunda mitad del siglo XIV en los subsidios y fogajes votados por las Cortes. MOTS DOLADER, Miguel Angel, «Régimen fiscal de las comunidades judias de Aragón en la Baja Edad Media: la aljama de Huesca en el siglo XJV", en Homenaje a Alfonso García Gallo, Madrid 1995, págs. 489-580.

70 Ledesma Rubio, María Luisa, «Proceso de Cortes de Maella de 1404», págs. 527-639.

7 SESMA, Angel y SARASA, Esteban, Cortes del reino de Aragón (1357-1451). Extractos y fragmentos de procesos desaparecidos, Valencia, 1976, pág. 58.

72 Sesma, Angel y SARASA, Esteban, Cortes del reino de Aragón (1357-1451). Extractos y fragmentos de procesos desaparecidos, págs. 105-132.

Hispania, LVI/3, nùm. 194 (1996) 885-944 
millon ${ }^{73}$. En este periodo todas los núcleos de población con categoría de villas y ciudades, tenían población judía con excepción de Sádaba, Pertusa, Bolea y Almudévar, en lo que a territorios de realengo se refiere. Los datos que aportamos a continuación son fragmentarios y presentan algunas deficiencias como las omisiones de núcleos de señorio - Ariza, Monzón, Borja...- y de realengo - Teruel ${ }^{74}$ o Albarracín ${ }^{75}$ -

En estas fechas la judería de Tarazona no supera los 50 inmuebles ${ }^{76}$, lo que se traduciría entre 200 y 250 personas (10-15\%) ${ }^{77}$. La aljama de Daroca, en el fogaje realizado por Martín I y dona Violante de Bar en 1398, arroja 27 casatas ${ }^{78}$; mientras que en la misiva que remite el infante don Alfonso a su padre Fernando I, el 31 de octubre de 1414, con motivo de las coacciones a las que son sometidos para su conversión, se habla de 40 casas ${ }^{79}$ (110-120 judíos). Calatayud declara 191 fuegos ${ }^{80}$ (760-860 habitantes), en un momento en que la ciudad contaba con 1.584 (12,5\% del total). En la villa de Luna, según un registro de cartas de 1409, se procede al cobro de 20 fuegos judíos, mientras que los cristianos los superan en catorce ${ }^{81}$. A tenor de la correspondencia mantenida por los ediles de Huesca con los perceptores del impuesto, se colige que la ciudad declara 630 casas, 434 de las cuales corresponden a cristianos, y el

73 SARASA SÁnCHEZ, Esteban, Aragón en el reinado de Fernando I (14I2-14/6). Gobierno y Administración. Constitución Política. Hacienda Real. Zaragoza, 1986, pág. 50.

74 A comienzos del siglo xv la ciudad congrega para las tres comunidades 482 fuegos. A.H.P.Z., Fogajes de las Cortes de Maella, 1405, fol. 55v.

75 En el primer tercio del siglo xv, Santa María de Albarracín, donde se censan también judios y moros, se declaran 147 fuegos. A.H.P.Z., Fogajes de las Cortes de Maella, 1405, fol. 55.

${ }^{76}$ Se extendía por las actuales calles de la Judería, Rúa Alta de Becquer, Rúa Baja y Aires. AINAGa ANDRÉs, María Teresa y Motis Dolader, Miguel Angel, «La juderia de Tarazona. Delimitación y morfología (1366-1500)», Destierros aragoneses. 1. Judios y Moriscos, Zaragoza, 1988, págs. 140-142 y plano núm. 2

${ }_{77} \mathrm{Si}$ atendemos a su capacidad fiscal, su población se mantiene estable, en la cota de los 300 fuegos desde el último cuarto del siglo Xjv hasta las Cortes de Valderrobles de 1429 , en que se fija el mismo número de contribuyentes. En 1386, Jaime del Spital, tesorero del brazo de las universidades, recibe del procurador del concejo 690 sueldos - a razón de 2 sueldos 10 dineros por casasegún la prorrata establecida en las cortes, incluyendo las aljamas musulmana y judia. A.H.P.Ta, Protocolo de Miguel Pérez de los Fayos, 1387, s.f.s.d. 10.Vl1-1387.

$\mathrm{Si}$ acudimos a las listas nominativas, en 1391 se documentan 108 personas; de ellos 55 varones mayores de edad (220-275 personas). MotIs DOLADER, Miguel Angel, «Convulsiones finiseculares y conflictividad social: la aljama judía de Tarazona y los pogroms de 1391», págs. 191-224.

78 A.C.A., Real Cancillería, Reg. 2 116, fol, 26 y BAER, Fritz, Die Juden in Christlichen Spaniest. Erster Teil: Urkunden und Regesten. Aragontien und Navarra, Berlin, 1929-36, pág. 778 in nota.

79 A.C.A., Cartas Reales, Fernando I, caja 4, núm. 529. Publ., BAER, Fritz, Die Juden in Chris. tlichen Spanien. Erster Teil: Urkunden und Regesten. Aragonien und Navarra, págs. 810-816.

80 A.C.A., Real Cancillería, Reg. 2.346, fols. 73v.-74. Cit. Cuella Esteban, O, «Los judíos bilbilitanos en tiempos del papa Luna", Primer encuentro de Estudios Bilbilitanos, Vol. II, Calatayud, 1983, pág. 133.

81 Agudo Periz, José Luis, «El señorío jurisdiccional de Maria de Luna. Un "Registro de Cartas" de 1409», Cuadernos de las Cinco Villas, 2 (1988), doc. 35. 
resto a las minorías - si comparamos el patrimonio inmobiliario de 1369 , los hebreos se situarian en torno a las 118 unidades fiscales-. Por otro lado, en un recuento inmobiliario realizado en 1462, se declaran un total de 844 casas repartidas del modo siguiente: cristianos, clérigos y órdenes (619), moros (90) y judios (135) ${ }^{82}$.

El número de fuegos de Jaca se eleva a 235 , con lo que la población excluidos los francos-- oscilaría en torno a las 1.050 personas ${ }^{83}$. De las receptas del fogaje se infiere que el vecindario judío contaría con 85 casas (380-425 personas) ${ }^{84}$. Llama la atención la alta fiscalidad y la elevada población en las Cinco Villas, donde no se asientan mudéjares ${ }^{85}$. Alli donde tenemos constancia de los fuegos totales y los privativos de judíos podemos establecer la implantación de población pechera (adviértase que existen estratos de población francos): Luna $(37 \%)^{86}$, Sos $(22,5 \%)^{87}$, Uncastillo $(28,15 \%){ }^{88}$, Daroca $(3,8 \%)$, Ruesta ${ }^{89}$.

Traduciéndolo al cómputo actual, obtendríamos algunos resultados orientativos: Luna (80-90 habs.), Biel (205-230 habs.), Sos del Rey Católico (70-80 habs.) ${ }^{90}$, Ejea de los Caballeros (235-265 habs ${ }^{91}$ ), Uncastillo (115-130 habs.) ${ }^{92}$, Calatayud (890-1.000 habs. $\left.{ }^{93}\right)$, Tarazona (200-225 habs.), Tauste (90-100 habs. ${ }^{94}$ ), Daroca (110-120 habs.) ${ }^{93}$, Biota (60-65 habs.), Jaca (340380 habs.), Huesca (470-525 habs.), Zaragoza (1.385-1.560 habs.), Alcañiz (120-135 habs.), Montalbán (120-135 habs.)

82 Balaguer, Federico, «Notas sobre la población judia de Huesca en el siglo xv», Sefarad, XLV (1985), pág. 348.

83 A.H.P.Z., Fogajes de las Cortes de Maella, 1405, fol. 55v.

84 A.H.P.Z., Fogajes de las Cortes de Maella, 1405, fol. 94.

85 LEDESMA RuBio, Maria Luisa, «La pervivencia del mundo islámico en Aragón: los mudéjares», en Historia de Aragón, Zaragoza, Guara Editorial, 1985, vol. 3, pág. 153. Este fenómeno no es infrecuente en muchos puntos de las vegas del Jalón y el Jiloca con implantación musulmana. GARCía MarCo, Javier, Comunidades mudéjares de Calatayud en el siglo xv, Calatayud, 1992, pág. 119.

8634 fuegos cristianos $/ 20$ fuegos judios.

87 La villa poseía en torno a ochenta fuegos sujetos a sisa, de ellos, según asientan los recaudadores, pagaron en tiempo y forma 49 casas cristianas y 14 judias. A.H.P.Z., Fogajes de las Cortes de Maella, 1405, fols. 36 y 75.

88 Las sisas fueron pagadas puntualmente por 60 hagares cristianos y 24 judíos. A.H.P.Z., Fogajes de las Cortes de Maella, 1405, fols. 4lv. y 75.

8914 fuegos cristianos/15 fuegos judios

90 A.H.P.Sos, Protocolo de Miguel Martínez de Sada, 1426-7, s.f.s.d

91 Sus constantes demográficas se mantienen próximas a los 59 fuegos. A.H.P.Z., Fogajes de las Cortes de Maella, 1405, fols. 39,60, 113 y 150.

92 En el último tercio del siglo xv, existen 23 cabezas de familia. A.H.P.Sos., Protocolo de Johan Coscón, 1475 , fols. 55v-56.

93 No olvidemos que una década antes poséa su judería como mínimo 222 casas. A.H.P.Z., Fogajes de las Cortes de Maella, 1405, fol. 60.

94 La aljama tributa por 22 casas. A.H.P.Z., Fogajes de las Cortes de Maella, 1405, fol. 151

95 A.H.P.Z., Fogajes de las Cortes de Maella, 1405, fols. 41 y 113.

Hisparia, LVI/3, núm. 194 (1996) 885-944 
La Controversia de Tortosa tendrá unas implicaciones demográficas notables, aunque su efecto sólo implicará al reino de Aragón ${ }^{96}$. Según las crónicas y las actas del cónclave, en el verano de 1413 se registran doscientos casos en Zaragoza, Calatayud y Alcañiz — patria de Jerónimo de Santa Fe-. De febrero a junio del año siguiente se ven afectadas ciento veinte familias en Calatayud ${ }^{97}$, Daroca - extinguida entre la primavera de 1414 y comienzos de $1415^{98}$-, Fraga ${ }^{99}$ y Barbastro ${ }^{100}$, amén de quinientos neófitos oriundos de Alcañiz, Caspe, Maella, Tamarite de Litera y Alcolea, alguna de las cuales desaparecerá $^{101}$. La gangrena del bautismo comienza entre los miembros más egregios de la mano mayor; sucumbiendo los dayyamim y los mukdamim. La oligarquía ciudadana posterior nacerá, en parte, de las filas judeoconversas, lo que termina por privar a las aljamas de la clase dirigente ${ }^{102}$, lo que originará una

96 Entre los representantes judios -según la carta que Bonastruch Dezmaestre, recogida en el Shébet Yehudá de Ben Verga y el manuscrito hebreo anónimo- se menciona entre 16 y 22 delegados de las comunidades judías con más proyección. RJERA I SANS, Jaume, La Crònica en hebreu de la Disputa de Tortosa, Fundasió Vives Casajuana, Barcelona, 1974.

97 Conocemos la identidad de veinticinco neoconversos, parte de los cuales se instalarán en la oligarquía concejil. CuElLA, Ovidio, «Los judios bilbilitanos en tiempos del papa Luna», Primer Encuentro de Estudios Bilbilitanos, Actas II, Zaragoza, 1979, pág. 136 y «Situación social y politica de la comunidad de Calatayud en el tránsito del siglo Xuv al XVy, Ibidem, págs. 141-142.

De la destrucción bilbilitana nos da constancia la contabilidad del maestre racional; el nivel contributivo entre los años 1403 y 1422 distninuye en un $90 \%$, pasando de 500 a 40 sueldos. Si la cota tributaria tuviera una repercusión poblacional —que no lo tiene, pues se convierten los linajes más acaudalados- en el primer decenio del siglo XV poseían casi un millar de efectivos, en la década de los veinte (1420- [422) no llegan al centenar. PILES Ros, Leopoldo, «Situación económica de las aljamas aragonesas a comienzos del siglo Xvm, Sefarad, X (1950), págs. 87-113.

98 De las familias conversas conocemos una buena parte por la querella interpuesta en 1426 ante el justicia de la ciudad, contra los jurados. Los veinticinco querellantes varones que comparecen permite barajar un índice bautismal dej $60 \%$, emigrando el $40 \%$ restante a las aldeas de la Comunidad y a Epiła, Montalbán y Vỉlafeliche, bajo jurisdicción señorial. Motıs DOLADER, Miguel Angel, «Dissapearance of the Jewish Community of Daroca at the beginning of the Xvth Century», Tenth World Congress of Jewish Studies, Jerusalem, 1990, págs. 143-150.

99 En 1333 Alfonso IV había concedido libertad de emigrar a esta villa hasta un máximo de seis familias, acogiéndose al mismo sistema exactivo que gozaban los judios residentes, con la excepción del pago de las sisas. SALARRULLANA DE DIOS, J., «Estudios históricos acerca de la ciudad de Fraga. La aljama de judios de Fraga», Revista de Archivos, Bibliotecas y Museos, XL (1919), págs. $69-90,193-206$ y 43 ]-46.

Esta villa había alcanzado con sus infanzones y aljamas mudéjar y judía 402 casas, índice de un núcleo floreciente. A.H.P.Z., Fogajes de las Cortes de Maella, 1405, fol. 161.

100 En la primera década del siglo xv la cjudad registra 292 fuegos judíos y cristianos, sin que sea posible dilucidar la proporción. A.H.P.Z., Fogajes de las Cortes de Maella, 1405. Esta comunidad carece todavía de un estudio necesario Vid. Rubio Calatayud, Adela y Blasco Sanchez, Santiago, «La aljama de los judios de Barbastro», Somontano, I (1990), págs. 85-101.

101 ZURITA, Jerónimo, Anales de Aragón, Zaragoza, 1980, vol. 5, pág. 416. Cfr. las menciones a las conversiones que se citan en las mismas actas. Pacios, Antonio, La Dispula de Tortosa, MadridBarcelona, C.S.l.C., 1957, sesión 12, pág. 63; sesión 14 págs. 63-66 y 74 y 76.

102 Cfr. Motis Dolader, Miguel Angel, «Dissapearance of the Jewish Community of Daroca at the beginning of the Xvth Century», op, cit. 
crisis multifactorial, como Tarazona, "considerantes que ha hovido grandes mortalidades, guerras e otras perplexidades por las quales la dita aljama yes diminuida de personas» 103 .

El efecto fulminante sobre la franja oriental del Reino lo deja patente un informe emitido a fines de 1414, donde se certifica que en Alcañiz ${ }^{104}$, Caspe, Maella, Alcorisa, Castellote y Molinos subsisten quince casas, mientras que en Fraga, «notabilis et populosa temporibus preteritis», "guey no hi ha alguna juderia" ${ }^{105}$. Los vecinos de Tamarite en 1412 habian sido deportados al exterior de la villa y su sinagoga consagrada al rito cristiano. Aínsa y Barbastro, en 1415 oficialmente no están habitadas ${ }^{106}$. Montalbán en el verano de ese mismo año veía partir a la última familia con destino a una judería de realengo ${ }^{107}$.

Monzón, que se nutre de una comunidad acaudálada gracias a la industria textil y de la peletería, constituye la excepción. En el monedaje de 1397, se contabilizan 87 cabezas de fuego judíos, pasando a 147 en 1451, lo que supone un incremento del $70 \%$; ello se debe a la inmigración de las aljamas de su entorno - Aínsa, Fraga, Tamarite, Montalbán, Castellote, Molinos, Caspe y Barbastro- ${ }^{108}$. Las actividades proselitistas fomentan la concentración en tierras de señorío - Monzón y Epila - y la ruralización —Comunidades de aldeas de Calatayud y Daroca-.

Todos estos factores inciden negativamente en el ámbito mesopoblacional: elevado índice de viudedad -en algunos puntos del Reino una de cada cuatro mujeres perdió su marido-; la conversión al cristianismo de varones y hembras en edad fértil -es más rara la conversión en la madurez o en la vejez-; la elevada mortalidad infantil que exige un número de alumbramientos mayor para lograr vástagos supértites; reducción en la esperanza de vida

103 Serrano y Sanz, Manuel, Orígenes de la dominación española en América, Madrid, Biblioteca de Autores Cristianos, 1918, pág. CCCCLIX.

104 Esta aljama, cuyo nacimiento institucional se produce en 1304, gracias a un privilegio otorgado por Jaime II y ratificado por Alfonso IV, permite la radicación de treinta familias, bajo la tutela jurisdiccional de la Orden de Calatrava. LALIENA CORvERA, Carlos, "Orígenes y extinción de una aljama judaica: Alcañiz, 1280-1414», en Destierros aragoneses. 1. Judios y Moriscos, Zaragoza, 1988, págs. 115-126.

105 GoÑ GAZTAMBIDE, J., «La conversión de la aljama de Fraga», Hispania Sacra, 25 (1960), págs. 205-6.

106 LACAVE RiAño, José Luis: «Las juderías aragonesas al terminar el reinado de Fernando I», Sefarad, XXXIX (1979), págs. 209-224.

107 Habia sido configurada mediante cédula otorgada por Jaime II, en 1309, en favor del comendador Artal de Huerta, llegando a contar en el periodo 1344-50, con un máximo de treinta familias. SAINZ DE LA MAZA, Regina, La orden de Santiago en la Corona de Aragón. La encomienda de Montalbán (I210-1327), Zaragoza, Institución Fernando el Católico, 1980, pág. 57 y «La aljama judia de Montalbán (1307-91)", Anuario de estudios medievales, 14 (1984), págs. 345-91. Vid etiam Benito Ruano, Eloy, «La juderia de Montalbán (Teruel)», Medievalia, 10 (1992), págs. 55-63.

108 En 1398 abandonaron la aljama de Fraga 36 familias, cuyo destino desconocemos, pero que no es infundado pensar que pusieran norte a tierras montisonenses. SESMA MUÑOz, Angel, "Demografia y sociedad: la población de Monzón en los siglos Xlıl-XV", págs. 687-89.

Hispenia, LVI/3, núm. 194 (1996) 885-944 
que conduce a que, en determinadas juderías, sólo la mitad de los hijos cuando cumplen la mayoría de edad conozcan vivo a su padre ${ }^{109}$, etc.

En tierras valencianas —donde la "controversia" no se dejó sentir, por el pronunciado declive en el que se encontraba esta minoría, ayuna de vitalidad-el liderazgo pasará de Valencia a Sagunto, mucho más poblada y dinámica, como demuestran los indicadores fiscales ${ }^{110}$. El incremento sufrido por Murviedro contrasta con el vaciado de Burriana que, a mediados del siglo Xv, basándonos en el perímetro de su judería, contiene 45 fuegos 'I'. Los datos aportados para Villarreal dan unas cifras próximas al medio centenar de judíos, experimentando una decadencia en la década de los setenta ${ }^{112}$.

La misma trayectoria describe, a cierta distancia, Castellón de la Plana que, en las vísperas de las persecuciones, alcanza casi el centenar de vecinos hebreos, padeciendo una crisis severa en 1433, cuando se desencadena otro brote epidémico, del que sobrevivirán once vecinos ${ }^{113}$. Atendiendo a los Libres de Values de Peytes, desde 1473 se detectan doce casas emplazadas en la parroquia de Santiago, cuatro años más tarde son cuatro, y en 1492 permanece un solo judío residente conocido 114

En la segunda mitad de la centuria algunos núcleos experimentan un retroceso irreversible. En 1471, en la verificación de los fuegos realizada por los jurados de Jaca, se contabilizan 74 casas hebreas; diez años después declaran: "[se halla] derruyda, despoblada et venida en grandissima miseria, inopia et pobreza, por guerras - las cabalgadas del rey francés-, fanbres, mortaleras, exacciones reales et en special por aver stado et seyer de present honerada de muchas cargas de censales» ${ }^{115}$. La aljama de Burriana, en 1486 se obliga a su comunidad a cerrar la sinagoga al culto y a encomendar sus kelé kódesh a los judíos saguntinos ${ }^{116}$.

109 Motis Dolader, Miguel Angel, Los judíos de Jaca en el siglo XV, op. cit.

110 Su población se resentirá en 1422 a raíz de un brote pestífero, no recobrándose hasta el segundo cuarto del siglo; de hecho, hasta 1438 solicitan condonaciones y moratorias en el pago de sus obligaciones hacendísticas. Hinojosa MonTAlvo, José, «Los judios del reino de Valencia durante el siglo XV", Historia Medieval. Anales de la Universidad de Alicante, 3 (1984), págs. 143-181.

iil Magdalena Nom DE DEU, José Ramón, La judería de Burriana, pág. 10.

112 Cfr. Donate Sebastiá, José María, Datos para la historia de Villarreal, Valencia, 1972.

113 Balbas, Juan Antonio, El libro de la provincia de Castellón, Castellón de la Plana, 1982, págs. 137-149; SÁNCHEZ AdELL, José, «La Edad Media Cristiana», en La provincia de Castellón de la Plana. Tierras y gentes, Castellón de la Plana, 1985, págs. 307-340; Magdalena Nom DE DEU, José Ramón, La aljama hebrea de Castellón de la Plana en la Baja Edad Media. Castellón de la Plana, 1978 y «Un documento sobre la expulsión de los judíos de Castellón de la Plana», Sefarad, LII (1992), págs. 149-154.

II4 Magdalena Nom de DEU, José Ramón, «Estructura socio-económica de las aljamas catellonenses a finales det siglo XV», Sefarad, 32 (1972), págs. 341-370; «Población, propiedades e impuestos de los judios de Castellón de la Plana durante la Baja Edad Media», Sefarad, 34 (1974), págs. 273-288 y «Nuevos datos sobre la aljama judía de Castellón de la Plana», Anuario de Filología, 4 ([978), págs. 199-246

115 A.M.J., Libro de Sesiones y Actas del Ayuntaniento /45/-98, caja 819, fol. 29.

116 Doñate Sebastiá, José María y Magdalena Nom DE DeU, José Ramón, Three Jewish Communities in Medieval Valencia, Jerusalem, 1990, págs. 185-86. 
Otros, por el contrario, mantienen su estabilidad, como La Almunia de Doña Godina, que cuenta con un mínimo de 77 varones mayores de edad, así como 46 casas, lo que se traduciría en 185-200 personas ${ }^{117}$. La judería de Ayerbe, bajo la tutela del señorío de Urriés, contaba con una comunidad de cuando menos 25 vecinos ${ }^{118}$, siendo superada por la próspera colectividad de Epila ${ }^{119}$.

Sin embargo, un hecho sorprendente a priori se genera a mediados del siglo XV; algunas juderías han de ampliar sus barrios por no poder albergar la población actual. En 1445, el call de Gerona se amplía por ser ya insuficiente ${ }^{120}$; Tarazona, en 1454, se expande por la "judería nueva", con lo que se incorpora algo más de un tercio de suelo urbano, pudiendo alojarse, grosso modo, 400 personas ${ }^{121}$. La judería extinta de Daroca, reanuda su vida institucional en 1458, cuando Juan II les asigna el antiguo solar de la juderia, ahora abandonado ${ }^{122}$.

\subsection{Población judía en la Corona de Aragón en 1492 '23}

La confluencia de los distintos factores, reseñados con anterioridad, motiva una fuerte contracción poblacional del segmento hebreo en la Corona de Aragón en el dintel previo a la expulsión, donde conviene poner énfasis no sólo en el bajo índice del crecimiento vegetativo - agredido con la emigración de los estratos más jóvenes en edad núbil y las mortandades generadas por las persecuciones finiseculares- sino también en la ulceración que supuso el parasitismo de una corriente conversora incentivada por las instancias políticas que contaba con el decidido respaldo del estamento eclesial ${ }^{124}$.

117 Marin Padilla, Encarnación, «Los judíos de la Almunia de Doña Godina, villa aragonesa de Señorío, en la segunda mitad del siglo xvm, Sefarad, LI (1951), pág. 328.

118 Durán Gudiol, Antonio, La judería de Huesca, Zaragoza, 1984, págs. 91-95.

119 Motrs Dolader, Miguel Angel ${ }_{r}$ «Articulación y funcionalidad del barrio judio de Epila en el siglo XV: convivencialidad o segregación», en Xudeus e Conversos na Historia, Ribadavia, 1994, págs. 263-317.

120 SOBREQUes VIDAL, Santiago, «Censo y profesión de los habitantes de Gerona en 1462», Anales del Instituto de Estudios Gerundenses, 6 (1951), págs. 193-246.

121 A.H.P.Ta, Protocolo de Antón Bueno, 1454, fols. 13-13v. AINAGA Andrés, Marja Teresa y Motis Dolader, Miguel Angel, «La judería de Tarazona. Delimitación y morfología (1366»]500)», pág. 143 .

122 Motis Dolader, Miguel Angel, «Ordenamiento urbanístico de la judería de Daroca: morfología y funcionalidad», Aragón en la Edad Media. Estudios de Economía y Sociedad, IX (1990), págs. 137-177.

En la confesión de Johan Díez, caballero, habitante en Belchite, ante el tribunal del Santo Oficio, donde narra la restauración de la judería de Daroca, depone que la primera oleada constó de seis o siete familias tan sólo. A.H.Prov.Z., Sección Inquisición, leg. 19/8, 1492, fols. 17-17v.

123 Este epígrafe reproduce parcialmente mi ponencia «Caminos y destierros de los judios de Aragón tras el Edicto de expulsión», en Segundos Encuentros Judaicos de Tudela, Pamplona, 1996 págs. 179-235.

${ }_{124}$ Motis Dolader, Miguel Angel, «Las comunidades judias del Reino de Aragon en tiempos del papa Benedicto XII] (1394-1423): estructuras de poder y gobierno aljamial», Jomadas sobre el VI Centenario del Papa Luna, Calatayud, 1996, págs. 120-146.

Hispania. LV1/3, núm. 194 (1996) 885-944 
En un reciente y meritorio ensayo de cuantificación realizado por J. Riera en tres momentos cardinales de la historia del judásmo hispano bajomedieval, como reportan los años 1391, 1419 y 1492, nos coloca sobre la pista de las dimensiones -en ocasiones casi trágicas-que adquirió este declive ${ }^{125}$ :

\begin{tabular}{|c|c|c|c|}
\hline Territorios & $\mathbf{1 3 9 1}$ & $\mathbf{1 4 1 9}$ & $\mathbf{1 4 9 2}$ \\
\hline Aragón & 9000 & 4500 & 3000 \\
\hline Cataluña & 10000 & 2000 & 1500 \\
\hline Valencia & 4800 & 400 & 600 \\
\hline Mallorca & 3000 & 300 & 100 \\
\hline
\end{tabular}

De su aritmética se infiere que, en el transcurso de tan sólo un siglo, las pérdidas podrían calificarse de graves para Aragón (-67\%), pero son comparativamente mucho más dramáticas en Cataluña $(-85 \%)$, Valencia $(-87,5 \%)$ o Mallorca $(96,5)$ que, en todo caso, dejaron de computar más de las tres cuartas partes de su población. Expresándolo mediante un diagramación obtendríamos la siguiente distribuciốn de rangos:

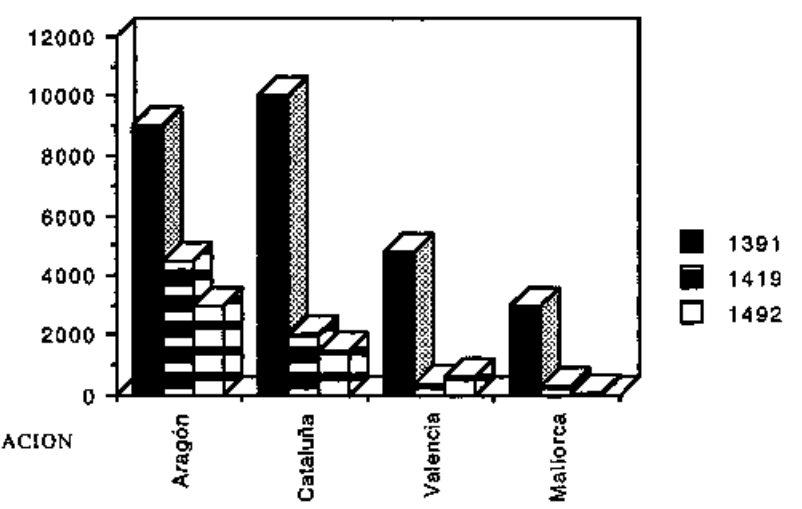

125 «Las cifras expresadas... se han elaborado a partir de algunos datos que parecen seguros, combinados con conjeturas que ahora no podemos señalar». RiERA SANS, Jaume, «Judios y conversos en los Reinos de la Corona de Aragón durante el siglo Xvm, en $I /$ Curso de Cultura Hispano Judia y Sefardi, Toledo, 1993, pág. 79.

R. H. BAUTIER en su articulo «Feux, population et structure sociale au mileu du XV siècle: l'exemple du Carpentras», Annales E.S.C., 14 (1959), pág. 27, propone un índice de 4,3 para los judios, frente al 5,2 de los cristianos; Manuel GraU MonSERRAT defiende un coeficiente de 4,5 en La judería de Besalú (Gerona) (siglos xıt al XV), Barcelona, 1977, págs. 11-19; «Familias judías de Besalú (s. XIII-XV). I. Bonanasc, Sutlam y Bellcaires, Anuario de Filología, 5 (1979), págs. 134-145 y «Familias judías de Besalú (s. XIJ[-XV). Los Monells (1300-1381)», Anuario de Filología, 6 (1980), págs. 285-307. 
No obstante, entiendo que, con todo tipo de cauciones, los datos obtenidos deben ser revisados en lo concerniente al reino de Aragón, porque el referido judaista tabula tres mil judíos como población total cuando éstos ${ }^{126}$, según la información indirecta que maneja, subsidiaria, a su vez, de otra ${ }^{127}$, es atribuida sólo a los expulsados.

La geografía judía de la época previa a la expulsión se puede inferir de la nómina de las localidades en las que se instruyen comisarios para supervisar la liquidación de los bienes en las comunidades organizadas jurídicamente- y se decreta la protección de los recintos judíos - colectividades con estructura urbanística- ${ }^{128}$. De conformidad con ella, en Aragón existía casi una treintena de comunidades de realengo ${ }^{129}$, si bien — subrayémosloalguna de ellas se encontraban oficialmente extinguida desde la Disputa tortosí ${ }^{130}$, pese a lo cual la referida provisión de cargos en estos últimos lugares podría responder a la existencia de intereses judíos en su demarcación, a que constituía una potencial escala en el camino al destierro ${ }^{131}$, o bien que la documentación no se hiciera eco de ulteriores restauraciones ${ }^{132}$.

Otros analistas, por el contrario, lo reducen a 3,5. MAGDALENA NOM DE DEU, J. R., «Estructura socioeconómica de las aljamas castellonenses a fines del siglo XV», Sefarad, XXXIl (1972) y «Población, propiedades e impuestos de los judios de Castellón de la Plana durante la Baja Edad Median, Sefarad, XXXIV (1974), págs. 274-75.

Si concedemos credibilidad a los demógrafos históricos que han trabajado en los dominios de la Corona de Aragón, se rechaza la teoría de familias muy numerosas, por lo que tienden a la moderación en los vectores alfanuméricos, con la aplicación del factor multíplicador 4. Dicho valor parece inalterable, a juzgar por sus estudios, hasta el mismo siglo XIX. SALAS AuSENS, José Antonio, «La población aragonesa a comienzos de! siglo xvln, en Fernando II de Aragón. El Rey Católico, Zaragoza, 1995, pág. 196 y SERRANo MONTALVo, Antonio, «La población altoaragonesa a finales del siglo Xv», Pirineos, 31 -32 (1954), pág. 215.

126 Riera SANS, Jaume, «Judíos y conversos en los Reinos de la Corona de Aragón durante el siglo $\mathrm{XV} »$, págs. $78-79$.

127 Cita a Blasco Martinez, Asunción, «Los judios del Reino de Aragón. Balance de los estudios realizados y perspectivas', en Actes del Primer Colloqui dels Jueus a la Corona d'Aragò, pág. 50, que a su vez se inspira en Serrano y Sanz, Manuel, Orígenes de la dominación española en América, pág. LXIl.

128 A.C.A., Real Cancillería, Reg, 3665 bis, fol. 134.

129 Motis Dolader, Miguel Angel, La expulsión de los judios del Reino de Aragón, Zaragoza, Diputación General de Aragón, Departamento de Educación y Cultura, 1990, vol. I, págs. 188-190.

130 Utilizo el término «disputa» en su sentido escolástico. Motis DOLADER, Miguel Angel, «Las comunidades judías del Reino de Aragon en tiempos del papa Benedicto XIII (1394-1423): estructuras de poder y gobierno aljamial», op. cit.

131 No se indicia ninguna comunidad radicada en el Reino de Mallorca, cuyos componentes de la aljama titular fueron obligados a tomar el bautismo poco después del ecuador del siglo Xv. RiERA Y SANS, Jaume, «La Historia de Santa Fide Catholica de Benet Espanyol (1548). La primera història dels jueus de Mallorca», en Fontes Rerum Balearicum, Palma de Maltorca, vol. 3, 1979-80, págs. $141-192$.

132 Las cartas de vasallaje contemplan ja solicitud de algunos judíos en localidades sin aljama como sucede el año 1479, en que Ruben Curi presta homenaje de Juan de Casaldaguilla, señor de Layana. A.H.P.Sos, Protocolo de Eximeno Busal, 1479, fol. $7 \mathrm{v}$.

Hispania, LVI/3, núm. 194 (1996) 885-944 
La nómina integraría las siguientes agrupaciones societarias: Zaragoza ${ }^{133}$, Calatayud ${ }^{134}$, Daroca ${ }^{135}$, Tarazona ${ }^{136}$, Borja 137, Teruel 138, Barbastro ${ }^{139}$, Alba-

133 Es la comunidad más populosa de toda la Corona, censándose 460 inmuebles sujetos a inventario, to que equivaldría a unas 1.840 ó 2.070 personas. [MOTIS Dolader, Miguel Angel, $L a$ expulsión de los judios de Zaragoza, Zaragoza, Diputación General de Aragón, Departamento de Educación y Cultura, 1985, pág. 33 y La expulsión de los judios del Reino de Aragón, vol. II, págs. 309-312]. La ciudad cuenta a fines del siglo xv con 3.969 fuegos. A.D.Z., Cortes de Tarazona, ms. 660 , fol. 1.

Esta colectividad -que en el año 1406 registraba 347 hogares pecheros [BLASCo, María Asunción, La judería de Zaragoza en el siglo XIV, Zaragoza, 1988, pág. 27] — tuvo suficiente dinamismo como para superar la durísima prueba de la Disputa de Tortosa. Si consultamos las actas o las crónicas de la época, en el estio del año 1413, se producen doscientas conversiones repartidas por las poblaciones de Zaragoza, Calatayud y Alcañiz [ZUR ITA, Jerónimo, Anales de Aragón, vol. 5, pág. 416].

Si damos crédito a las fuentes fiscales, los indicios de un resquebrajamiento de la cohesión intracomunitaria prosiguen al año siguiente. Hasta tal punto de que en la libranza del pago del arrendamiento de las sisas del vino y de la carne, que había entrado en vigor a comienzos del mes de septiembre de 1414, el clavario advierte que, pese a ascender el contrato a 59.000 sueldos anuales, se habia devaluado, de conformidad con lo capinulado, a 57.440 sueldos, a causa de los 78 judios que se habian convertido a la fe católica, a tenor de 20 sueldos per cápita.

Este descenso contributivo, por razón de los bautizandos, no deja de aumentar. A propósito de! pago del quinto del precio de la arrendación a que tenía derecho el monarca, relativo al año 1415 , se detrae lo relativo a los 130 judíos convertidos, entre los meses de enero y abril, ambos inclusive, aunque esta vez, conociendo que esta corriente previsiblemente aumentaría, se tasan en 13 sueldos 4 dineros per cápita.

En un periodo de tan sólo ocho meses, si atendemos a la población total de una década atrás, el número de conversos se situó en el 14\%; porcentaje que podria alcanzar un índice del $21 \%$ si lo hiciéramos extensible a un año, sobre la base del mismo ritmo ponderado de crecimiento de los otros meses. De todas formas, la quinta parte de los judios zaragozanos se habría convertido como mínimo en el transcurso de un trienio, tal y como reflejan los pagos realizados por este mismo concepto en el año siguiente, tras detraer tos 815 sueldos 4 dineros de otros 60 judeoconversos que, en el período comprendido entre septiembre del año 1415 y agosto del siguiente, se habían bautizado. SARASA SÁNCHEZ, Esteban, Aragón en el reinado de Fernando I(14/2-14/6). Gobierno y Administración, Constitución Política y Hacienda Real, Zaragoza, Institución Fernando el Católico, 1986, pág. 170 (ejercicio 1414); pág. 191 (ejercicio 1415); pág. 177 (ejercicio 1415-16), pág. 211 y Motıs DOLADER, Miguel Angel, «Minorías confesionales y jurisdicción eclesiástica: proceso criminal contra Azday Aventilca, judio de Zaragozan) (en prensa).

134 Tras la conferencia de Tortosa se identifican veinticinco apóstatas, parte de los cuales llamados a ocupar altos cargos en la oligarquía ciudadana. CuELLA, Ovidio, «Los judíos bilbilitanos en tiempos del papa Lunaw, Primer Encuentro de Estudios Bilbilitanos, Actas II, Zaragoza, 1979, pág. $136 \mathrm{y}$ «Situación social y política de la comunidad de Calatayud en el tránsito del siglo XIV al XV», Ibidem, págs. 141-142.

La destrucción queda reflejada en la contabilidad del maestre racional, donde el nivel contributivo entre los años 1403 y 1422 disminuye en un $90 \%$, pasando de 500 a 40 sueldos. Si la cuota tributaria tuviera una repercusión poblacional —que no lo tiene, pues se convierten los linajes más acaudalados-- en la década de los veinte (1420-1422) hubiera pasado de tener un millar de personas a no exceder el centenar [Prles Ros, Leopoldo, «Situación económica de las aljamas aragonesas a comienzos del siglo XVm, Sefarad, $X$ (1950), págs. 87-113] Ello obliga a una rigurosa 
rracín ${ }^{140}$, Jaca ${ }^{141}$, Huesca ${ }^{142}$, Fraga ${ }^{143}$, Monzón ${ }^{144}$, Ejea de los Caballeros ${ }^{145}$, Tauste ${ }^{146}$, Uncastillo ${ }^{147}$, Sos del Rey Católico ${ }^{148}$, Alcolea, Alcañiz ${ }^{149}$, Montal-

política fiscal basada en el principio de la corresponsabilidad. CuElLA, Ovidio, «La recuperación en Calatayud y su comunidad en los inicios del siglo Xvm, en Homenatge a la Memòria del Prof. Dr. Emilio Sáez, Barcelona, 1989, pág. 385.

$\mathrm{Si}$ nos atenemos a los judios censados en la documentación notarial en la última década, la aljama podia contar con unos efectivos próximos a los 550-650 habitantes. MOTIS DOLADER, Miguel Angel, The Jews in Calatayud (1492-1500). Regesta of documents from the Archivo de Protocolos de Calatayud. Sources for the History of the Jews in Spain. núm. 2, The Henk Schussheim Memorial Series, Jerusalem, 1990, pág. 31.

135 Su disolución tiene lugar, como muy tarde, en el primer tercio de 1415. Conocemos la identidad de veinticinco neoconversos que incoan un proceso ante Miguel de Molinos, Justicia de Daroca, en 1426 contra los jurados de la ciudad, los cuales pretendían que se surrogaran en las deudas de la comunidad judia y se encuadraran en las parroquias para ser repercutidos en las derramas e impuestos. Los demandantes podrían representar un $60 \%$ de la juderia -entre 1398 y 1414 su población oscila entre 27 y 40 fuegos, cuando la ciudad suma 709 fuegos, incluidas las minorias, amén de 29 casas infanzonas--; el resto prefirió migrar a Epila, Montalbán y Villafeliche, bajo jurisdicción señorial. Motıs DOLADER, Miguel Angel, «Disappearance of the jewish community of Daroca at the beginning of the XVth. centuryn, Tenth World Congress of Jewish Studies, division B. volume I: The History of the Jewish Studies (From the second Temple period until the Middle Ages), Jerusalem, 1990, págs. 143-150.

La extinta comunidad reanuda su vida institucional en 1458 , cuando Juan If les asigna el antiguo solar de la judería, que ahora cuenta con un parque inmobiliario de al menos 22 viviendas censadas, aunque el plano parcelario alcanza la cuarentena. Motis DoLAder, Miguel Angel, «Ordenamiento urbanístico de la judería de Daroca: morfología y funcionalidad», Aragón en la Edad Media. Estudios de Economía y Sociedad, IX (1990), págs. 147 y 153-165.

136 En la franja occidental, menos afectada por los corriente catequizadoras a fortiori, se añadieron otros factores a la contracción de esta minoría, como indica en las takkanôt aprobadas en el segundo decenio del siglo xv por la reina doña Maria, uconsiderantes que ha hovido grandes mortalidades, guerras e otras perplexidades por las quales la dita aljama yes diminuida de personas» [SERRANo y SANZ, Manuel, Orígenes de la dominación española en América, pág. CCCCLIX]. Ello no obsta para que en el «Jurament de los jodios logreros», celebrada el primer sábado de octubre de 1407, presente el triunvitaro del adelantazgo formado por Levi Pamplonés, Simuel Avencahadía y Abraham Leví, desfilen ante el baile 31 «jodios que querrian prestar sus dineros a logro", tres de las cuales mujeres. A.D.Z., Fondo de Veruela, Protocolo de Garcia López de Longares, 1407, s.f.s.d.

En 1454 la judería genera, a modo de hipóstasis, un barrio denominado la «judería nueva», con lo que se incorpora algo más de un tercio de suelo urbano, pudiendo alojarse, grosso modo, un minimo de 400 personas. Hasta entonces en la judería cerrada se censaban unos cincuenta inmuebles residenciales. AINAGA ANDRÉs, Maria Teresa y Motis DOLADER, Miguel Angel, «La judería de Tarazona. Delimitación y morfologia (1366-1500)», págs. 140-143.

${ }_{137}$ Residen en el último tercio del siglo xv en torno a 350 hebreos. Motts DoLADER, Miguel Angel, Los judios de Borja en el siglo xv, págs. 25-26 y 66-87.

13x Según el historiador local, que tuvo acceso a las Actas de los Jurados de 1492, doscientos judíos se hicieron a la mar, mientras que el resto, en cantidad equivalente, tomaron el bautismo. FLoRiano, Antonio C., La aljama de judíos de Teruel y el hallazgo de su metrópoli, Teruel, 1926, pág. 17.

La población no debió variar en grado sumo porque, en un memorial elevado en enero de 1486 por los jurados del concejo para que negociasen con las autoridades de las sisas del Reino de Aragón, se consideran agraviados por las 505 casas «induzidas», máxime tras la implantación del Santo Oficio, que había arruinado «de mas de huna veintena de casas de las mas abonadas de toda la ciudat, que ha uhutilidat de la dita sisa suplian en numero de mas de L». A.M.T, Sección Protocolos, caja 26 , Concejo, 1486 , papeles sueltos.

Hispania, LV]/3, nùm. 194 (1996) 885-944 
bán ${ }^{150}$, Magallón 151, Huesa del Común 152, Muniesa y Segura -Oliete 153_, Caspe ${ }^{154}$, Tamarite de Litera ${ }^{155}$, Cariñena ${ }^{156}$, Alagón ${ }^{157}$, San Esteban de Litera y Sariñena ${ }^{158}$.

Un indicio plausible de la proporcionalidad hebrea en la ciudad puede colegirse en las prorratas alzadas en los gastos comunitarios. $\mathrm{Si}$ atendemos, por ejemplo, al reparto alícuoto de los costes de] nuevo reloj adquirido por el municipio el año 1483, valorado en mil sueldos, distribuidos en cinco tandas de doscientos sueldos anuales, sabemos que la ciudad abona 130 suejdos; el capítujo concejil, 25 sueldos; los judios, 25 sueldos; y los moros, 20 sueldos. Es decir, manejando este parárnetro orientativo, los judios representan en tomo al $12,5 \%$ del total o, lo que es lo mismo, en torno a los 65 fuegos fiscales. A.H.P.Te., Sección Ayuntamiento, Libro de Acuerdos, Johan López de Montreal, 1483-84, fol. 43.

139 A fines de enero de 1479, los miembros del Concejo resuelven «que si ningun judio queria venir ad abitar a la ciudat, que sia menestral, que en tal caso este en su casa, en la forma que stava Cordovi, $y$ que no tienga botiga en la dita ciudat, y que se lançe de conpartimiento aquello que a los jurados sera bien vistoy. A.H.P.H., Protocolo de Juan del Pueyo, 1478.79, Barbastro, fol. 21. Cit. MotIS DOLADER, Miguel Angel, «Propedéutica sobre las "Actas Municipales" como fuente para el estudio de los judios aragoneses en la Edad Media", en III Jomadas de Metodologia de la investigación cientifica sobre fuentes aragonesas, Zaragoza, 1988, págs. 349-364.

De cualquier modo, permanecerá afincada en la ciudad una activa comunidad conversa. SESMA MuÑoz, Angel, «Los Santángel de Barbastro: estructura económica y familiar», Aragón en la Edad Media, 9 (1991), págs. 121-136

${ }_{140}$ El registro de los judios de Albarracin, arroja una cantidad próxima al centenar de casas, pues uno de los historidores locales que tuvo acceso al inventario de sus bienes, itremisiblemente perdido, apunta «del inventario y tasación de las casas resulta que éstas pasaban de ciento y ocupaban desde la torre que llaman de Dofta Blanca, hasta el arco que habia junto a las casas de Pablo Martínez, maestro de Granática». LAGUiA, Tomás César, "La geografia urbana de Albarracín», Teruel, 24 (1960), pág. 51.

141 La ciudad registra en el siglo xv un equivalente a 270 casas fiscales, de las que 74 corresponden a los judios. Motis Dolader, Miguel Angel, «Aproximación a la evolución demográfica de la comunidad judía de Jacan, en Homenaje a Don Antonio Durán Gudiol, Huesca, 1995, pág. 612.

142 En un recuento inmobiliario realizado en 1462 , se declaran un total de 844 casas repartidas del modo siguiente: cristianos, clérigos y órdenes (619), moros (90) y judios (135) —entre 540 y 600 personas--. BALAGuer, Federico, «Notas sobre la población judia de Huesca en el siglo xV», Sefarad, XLV (1985), pág. 348.

Otras aportaciones reducen su guarismo a 450 habitantes. DURȦN GUDIOL, Antonio, La judería de Huesca, Guara Editorial, Colección Básica Aragonesa/46, Zaragoza, 1984, pág. 141.

143 Desaparecida oficialmente tras la Disputa de Tortosa. SALARRULLANA DE Dios, J., «Estudios hisłóricos acerca de la ciudad de Fraga. La aljama de judios de Fraga», Revista de Archivos, Bibliotecas y Museos, XL (1919), págs. 69-90, 193-206 y 431-46.

144 Monzón se beneficia en grado sumo de la emigración de judios de las aljamas de sus alrededores - Ainsa, Fraga (en 1398 abandonan la ciudad 36 familias con rumbo desconocido), Tamarite, Montalbán, Castellote, Molinos, Caspe y Barbastro- que no tienen otro remedio que trasladar su domicilio ante la disolución de sus respectivas comunidades. Un exponente de semejante expansión to corrobora el monedaje de 1397, que arroja 87 fuegos judios, mientras que media centuria más tarde, el afio 1451, la cifra se dispara a 147, lo que supone un incremento del $69 \%$ en el términe de una sola generación. SESMA MUNNOZ, Angel, «Demografia y sociedad: la población de Monzón en los siglos XIII-XV», Principe de Viana, 47 (1986), Anejo 3, págs. 687-89 y VILADÉs CASTiLlo, José Maria, «La juderia de Monzón: Notas para su estudiom, Cuadernos CEHIMO, 7 (1986), págs. 30-32.

En la última década del siglo xiv se conoce una lista integrada por ochenta judíos. PITA MERCE, Rodrigo, «Una lista de judíos de Monzón en el año 1397», Ilerda, 44 (1983), págs. 287-303. 
Por su parte, el Reino de Valencia presenta concentraciones judías, más o menos numerosas ${ }^{159}$, en la ciudad de Valencia y en las poblaciones de

145 Habitan su judería una cantidad próxima a las 24 familias. Cabezudo Astrain, José, «La expulsión de los judios de Ejea de los Caballeros», Sefarad, XXX (1970), págs. 349-363.

146 Se transfieren al lugarteniente del baile de Aragón y del tesorero general diecisiete inmuebles que pasan a ser propiedad del Patrimonio regio o son restituidas a los conversos. A.H.P.Z., Prolocolo de Miguel Villarreal, 1495-96, fols. 69-72 y $12 \mathrm{~L}-122$.

147 Mantiene una población relativamente estable, no fluctuando demasiado respecto a los 29 fuegos que se registran en el primer tercio del siglo de un número global de 103 fuegos. Motis DOLADER, Miguel Angel, «La jurisdicción del Justicia de Uncastillo y la comunidad judía en el siglo xv: la prenda judicial», Aragón en la Edad Media, XII (1995), pág. 202.

${ }_{148}$ Se realiza el inmatriculación notarial de los bienes de un total de 30 hogares, excluyendo la sinagoga, lo que supondría una población que oscilaria entre las 120 ó 135 personas. [A.H.P.Sos, Protocolo de Bartoloné Spanyol, 1492-7, s.f.s.d.]. Esta valoración podria incrementarse a 34 familias. Cabezudo Astrain, José, «La judería de Sos del Rey Católicom, Sefarad, XXXII (1972), pág. 90.

149 Esta aljama, cuyo nacimiento institucional śe produce en 1304 , gracias a un privilegio otorgado por Jaime II, permitiendo que se afincaran treinta familias, bajo jurisdicción de la Orden de Calatrava. LALIENA CORVERA, Carlos, «Orígenes y extinción de una aljama judaica: Alcañiz, 12801414», Destierros aragoneses. I. Judios y Moriscos, Zaragoza, 1988, págs. 115-126.

150 Se fundación se debe a Jaime II, en 1309 , a instancia del comendador Artal de Huerta, llegando a contar en el período 1344-50, con un máximo de treinta familias. En el verano del año 1415 se registra la partida de la última familia que residía en la villa con destino a una judería de realengo SAINZ DE LA MAZA, Regina, La orden de Santiago en la Corona de Aragón. La encomienda de Montalbán (1210-1327), Institución Fernando el Católico, Zaragoza, 1980, pág. 57 y «La aljama judia de Montalbán (1307-91)», Anuario de estudios medievales, 14 (1984), págs. 345-91.

151 Su población fluctuaria entre 110 y 130 individuos. MorIS DOLADER, Miguel Anget, "Los judios de Magallón a fines del siglo xv y su expulsión", Cuadernos de Estudios Borjanos, XVI]XVIII, pág. 185.

152 En la reunión aljamial celebrada en la villa el año 1487 con el propósito de suscribir un censal que a fectaba a toda la baronia, asisten cinco pater familias. [A.H.P.M., Protocolo de Juan d'Ovón, Muniesa, 1487, s.f.s.d.] Bien es verdad, que en 1492, tenemos constancia de nueve familias por las reuniones aljamiales. MotIS DoLAder, Miguel Angel, The jews in Calatayud (1492-1500). Regesta of documents from the Archivo de Protocolos de Calatayud. doc. 9.

153 En principio una población de poca rclevancia mantiene en su seno una considerable aljama compuesta en sus órganos colegiados por dos adelantados y dos consejeros, y un mínimo de cinco cabezas de familia, convocados por el corredor acreditado. A.H.P.M., Protocolo de Juan d'Ovón, Muniesa, 1490-91, fols. 107-107v.

154 Desaparecerá junto con Alcañiz, Maella, Tamarite de Litera y Alcolea. ZuRITA, Jerónimo, Anales de Aragón, vol. 5, pág. 416 y PACios, Antonio, La Disputa de Tortosa, sesión 12, pág. 63; sesión 14, págs. 63-66, 74 y 76 .

En un informe pericial remitido a fines de 1414, se certifica que en Alcañiz, Caspe, Maella, Alcorisa, Castellote y Molinos subsisten quince casas, mientras que en Fraga, unotabilis et populosa temporibus preteritis... guey no hi ha aiguna juderia». Gónı GAZTAMBIDE, J., «La conversión de la aljama de Fraga», Hispania Sacra, 25 (1960), págs. 205-6.

155 La historiografía no ha estudiado en demasía la capacidad de regeneración experimentada por algunas aljamas, aunque éstas sean marginales. Este es el caso que nos afecta, tal y como se evidencia de la prueba testifical practicada a la mujer de maestre Fernando, sastre, judeoconverso, vecino de la localidad, apresada por el Santo Oficio en Huesca bajo la imputación de apostasia y prácticas heréticas quien, a requerimientos del fiscal, manifiesta las circunstancias que rodearon su conversión: «Dize que ella seyendo judia y biviendo en la villa de Tamarit de Litera con el dicho su

Hispania, LV1/3, núm. 194 (1996) 885-944 
Sagunto ${ }^{160}$, Crevillente, Alcira ${ }^{161}$, Alicante ${ }^{162}$, Elche ${ }^{163}$, Orihuela ${ }^{164}$, Játiva ${ }^{165}$ y Segorbe ${ }^{166}$, a la que deberíamos incorporar aljamas como la de Castellón ${ }^{167}$.

marido, se fueron al tiempo del destierro de los judios a Tarragona, y despues se volvieron a la dicha villa de Tamarit donde se babtizaron ella y el dicho su marido, e se fizieron christianos, ensemble con un fijo que tienen, que entonçes se fizo christiano, y en todo este tiempo desque es christiana dize que todas las quaresmas a comido carne y esto con licencia del bicario e bicarios de Tamarit». A.H.Prov.Z., Sección lnquisición, leg. 26/3, 1504, fol. 3.

156 Según los fondos de Desamortización que he tenido ocación de consultar, la sinagoga se radicaba en la actual capilla del Santo Cristo de Santiago. A. Dioc. Z., Desamortización, Daroca, caja núm. 9,1854 , fol. 29 ,

157 En PÉrez VIÑUALES, Pilar, “Judíos en Alagón», en Destierros aragoneses: I. Judios y Moriscos, Ponencias y Comunicaciones, Zaragoza, 1988, Institución Fernando el Católico, págs. 127-133, no se esclarece la población que allí residja

158 Motis Dolader, Miguel Angel, La expulsión de los judíos del Reino de Aragón, vol. I, págs. 188-190.

159 No consta la judería de Burriana, obligada en 1486 a cerrar su sinagoga y a transferir su patrimonio litúrgico a los judios de Sagunto para su custodia. Doñate Sebastia, José María y MAGDALENA NOM DE DEU, José Ramón, Three Jewish Communities in Medieval Valencia. Jerusalem. 1990 , págs. 185-86.

Similar perfil presenta la aljama de Castellón de la Plana ta cual, si prestamos atención a los Libres de Values de Peytes, experimenta un fortisimo retroceso, pasando de doce inmuebles en la parroquia de Santiago, en 1473, a cuatro en 1477 y desembocando en la postración de 1492 en que sólo tenemos certifícación de un judio residente. MAGDALENA NOM DE DEU, José Ramón, «Estructura socio-económica de las aljamas catellonenses a finales del siglo XV», Sefarad, 32 (1972), págs. 341-370; «Población, propiedades e impuestos de los judios de Castellón de la Plana durante la Baja Edad Media, Sefarad, 34 (1974), págs. 273-288; La aljama hebrea de Castellón de la Plana en la Baja Edad Media, Castellón de la Plana, 1978; «Nuevos datos sobre la aljama judía de Castellón de la Plana, Anuario de Filología, 4 (1978), págs, 199-246 y «Un documento sobre la expulsión de los judíos de Castellón de la Plana), Sefarad, LIl (1992), págs. 149-154.

160 Ostenta la hegemonía del Reino (a lo largo de la segunda mitad del siglo xv, habian experimentado un crecimiento lento pero sostenido gracias al impulso del crecimiento natural y los inmigrantes de la Plana de Castellón) con un centenar de casas. PlLES Ros, Leopoldo, «La expuisión de los judíos en Vafencia: repercusiones económicas", Sefarad, XV (1955), pág. 100 y MEYERSON, Mark, «The Jewish Community in Murviedro (1391-1492), The Jews of Spain and the Expulsion of 1492, Los Angeles, University of Southern California, 1992 (en prensa).

Pudo llegar a alcanzar las setecientas personas, no superando el $6,8 \%$ de la población total. Hinojosa Montalvo, José, «Apuntes para la demografia de la aljama de Sagunto en los siglos bajo medievales», Sefarad, LV (1995), págs. 280 y 282.

lit Chabas, R., «Sobre los judíos de Alcira», El Archivo, 4 (1890), págs. 289-408 y Piles Ros, Leopoldo, «La juderia de Alcira (Notas para su estudio)», Sefarad, XX (1960), págs. 363-376.

1 if2 Su presencia, no ya en la capital, sino en su territorio, es "reducidísima». Hinojosa MONTALVO, José, «Bosquejo histórico de los judíos en tierras alicantinas durante la Baja Edad Media», en I: Colloqui d'Historia dels Jueus a la Corona d'Aragó, pág. 220.

163 Se ignora incluso si los tres hogares que se contabilizan en 1465 persisten en vísperas de la expulsión. Hinojosa MonTalvo, José, "Los judios de Elche durante la Baja Edad Media», Homenaje al doctor Juan Torres Fontes, Murcia, 1987, págs. 791-808.

ICA Mediado el siglo XIV, necesitaban una carga de vino para celebrar la Pascua. HiNoJosA Montalvo, José, «Bosquejo histótico de los judios en tierras alicantinas durante la Baja Edad Media», pág. 220. 
En cuanto al Principado de Cataluña ${ }^{168}$, se enumeran las poblaciones de Lérida ${ }^{169}$, Tortosa ${ }^{170}$, Tarragona ${ }^{171}$, Vich, Urgel, Balaguer, Cervera ${ }^{172}$, Gerona 173, Castellón de Ampurias y Tárrega ${ }^{174}$.

lis Suman una población de 248 judios. Hinojosa MonTalvo, José, «La judería de Xàtiva en la Edad Media), Espacio. Tiempo y Forma. Historia Medieval, 6 (1993), pág. 407.

106 Magdalena Nom de Deu, José Ramón, «La aljama judía de Segorbe en un "responsurn" de Rabi Ishaq bar Seset Perfet», Boletín de la Sociedad Castellonense de Cultura, 59 (1983), págs. 855-893.

167 Según el testimonio de historiadores locales, fueron expulsadas en torno a veinte familias. Vid. Donate Sebastia, J. y Magdalena Nom de Deu, J. R., Three Jewish Communities in Medieval Valencia, Castellon de la Plana, Burriana, Villarreal, Jerusalem, 1990, Hispania Jucaica, vol. 8, pág. 60 .

เ68 Como ejemplo comparativo, en esta demarcación, durante el siglo XIV, existen comunidades organizadas aljamialmente que cuentan con barrio propio -Gerona, Castetlón de Ampurias, Besalú y Torrella de Montgrí-; comunidades que ocupan una o dos calles -Bisbal, Peralada, Bañolas y San Feliú de Guíxols-y, por último, colectividades formadas por una pocas familias judias en régimen de radicación eventual —Camprodón, Verges, Báscara y Caldes de Malavella-. RIERA I SANS, Jaume, «La Catalunya jueva del segle XIV», L'Avenç, 25 (1980), págs. 205-7.

16i Se ha podido reconstruir una lista, de ambos sexos, extraida del fogaje de 1491, donde figuran 30 personas [BERTRAN I RolGe, Prim, «Notes de demografia $i$ onomàstica lleidatanes de finals de ['Edat Mitjana. El fogatge del 1491", Acta Medievalia, 1 (1980), págs. 167-168] ó 38, según otros [PITA I MERCE, Rodrigo, «Los últimos años de existencia de la aljama hebrea de Lérida (14901492) ", Merda, 43 (1982), págs. 445-455], lo que entrañaria unas 170 almas [RJERA SANs, Jaume, "Judios y conversos en los Reinos de la Corona de Aragón durante el siglo xv», pág. 79].

170 El «memorial fet e format de manament de la magestat del rey nostro senyor dels inventaris e actes fets dels bens dels jueus de la ciudat», inmatricula 32 casas A.C.A. Real Patrimonio, Reg. 389 , asiento 359 .

171 Se encuentra muy disminuida, si bien algunos historiadores que se ocupan del tema no aportan datos contrastables. SeCALL Y GUELL, Gabriel, Les Jueries Medievals Tarragonines, Valls, 1983, págs. 531-532.

172 Siendo una ciudad muy modesta, tiene un call compuesto, a mediados de siglo, por medio centenar de familias. [DURAN I SANPERE, Agusti, «Referencies documentals del call de juheus de Cerveray, Discursos llegits en la Real Academia de las Buentas Letras de Barcelona. Barcelona, 1924, pág. 24 y SANMARTI Roset, Maria-M., «La expulsió dels jueus de Cervera segons el llibre del "Manifiest" de l'any 1490», Universitas Tarraconensis, 4 (1981-82), págs. 87-93]. Estudios recientes identifican para esta úitima década de permanencia 31 judios. Llobet I PoRTELla, Josep M., «Els jueus de Cervera i Tàrrega, l'any $1492 »$, en $\mathrm{r}$. Colloqui d'Historia dels Jueus a la Corona d'Aragó, pág. 357.

173 La aljama estaba integrada por unas veinte familias (24 contribuyentes), habiendo sido ampliado su recinto en 1445. MiRAmbel Belloc, Enrique, «Los judios gerundenses en el momento de la expulsións, $X$ Congreso de Historia de la Corona de Aragón: La Corona de Aragón y el Mediterráneo, aspectos y problemas comunes desde Alfonso el Magnánimo a Fernando el Católico (1415-1515), vol. [V, Comunicaciones, Zaragoza, 1984, págs. 253-265; «Los judíos gerundenses en el momento de la expulsión», Anuario de Estudios Gerundenses, XXIV (1978), págs. 5-14 y «Documentos para el ordenamiento jurídico y económico del barrio judio de Gerona (siglo Xv)» en La ciudad hispánica durante los siglos XIII al xVl, Madrid, 1985, vol. 2, págs. 1465-1468.

En un documento expedido por los judios de la aljama, en julio de 1492, donde se procede a la enajenación de la sinagoga comunitaria, comparecen Lleó Aninay, Salamó Esdres, Salamó Samuel

Hisparici, LVL/3, núm. 194 (1996) 885-944 
Amén del casi medio centenar de enclaves señalados en los territorios peninsulares de la Corona, deben agregarse los núcleos bajo jurisdicción señorial, algunos muy descollantes, los cuales presentan peculiaridades inherentes. Haciendo un rápido recuento, en Aragón se ven afectadas las localidades y posesiones de Epila ${ }^{175}$ (conde de Aranda); Belchite ${ }^{176}$ e Híjar ${ }^{177}$ (conde de Belchite y señor de Híjar); Pedrola (conde de Ribagorza, sobrino del rey) 177 bis; Cetina y Séstrica (vizconde de Biota), Algerri y Albesa (Pedro de Mendoça), Estadilla (Felipe de Castro); Pina ${ }^{178}$ (Blasco de Alagón), Ariza ${ }^{179}$ (Guillén de Palafox); Illueca y Arándiga (Jaime Martínez de Luna, camarlengo); Villafeliche (Francisco Ferrando de Luna); Ayerbe ${ }^{800}$ (Joan Pérez de Urriés); Naval y Verbegal (Joan de Torrellas); Fuentes de Ebro (Joan Ferrández de Heredia, gobernador de Aragón); Mora de Rubielos (Joan Ferrández de Heredia, consejero real); Estercuel y Pertusa (Mosen Berenguer de Bardaxí); Quinto (Francisco de Funes y de Villalpando); Albalate. Montearagón y Rueda ${ }^{181}$ (El

y Levil Issach, rectors de la aljama, y Astruch Abraham, Bonastruch Benvenist, Jucef de Piera, Mossé Vidal, Belshom Caracosa, Benet Tolosa, Vidal Astruch, Benvenist Astruch y Astriuch Tarós. BATLLE GALLART, C., "Solución al problema de las dos sinagogas de Gerona», Sefarad, XIX (1959), págs. 301-320 y Escriba i Bonastre, Gemma y Frago i Pérez, María Pilar, Documents dels jueus de Girona /124-1595, Girona, s. a.

174 La documentación notarial inmatricula un total de 26 judíos avecindados en la localidad. LlOBet I PORTELLA, Josep M., «Els jueus de Cervera i Tàrrega, J'any 1492», pág. 364.

175 De las transacciones onerosas y cesiones arrendaticias se deducen un total de 42 casas. MotTS DOLADER, Miguel Angel, «Articulación y funcionalidad del barrio judio de Epila en el siglo xv: convivencialidad o segregación», Congreso Internacional Judios y Conversos en la Historia, Ribadavia, 1994, págs. 263-317.

176 En un proceso inquisitorial instruido contra Joan Díez, caballero de la villa, comparecen para prestar declaración nueve pater familias tan sólo durante el mes de mayo de 1492. A.H.Prov.Z., Sección Inquisición, leg. 19 núm. 8, 1492, fols. 5-12.

177 Hijar alberga una importante colectividad si atendemos al hecho, quizás aleatorio, de que en un protocolo notarial de la villa se incluyen, entre los meses de septiembre y octubre de 1488 ó 1489 (el legajo se ha conservado muy amputado, por lo que no permite hacer mayores precisiones) treinta y siete otorgantes y testigos. A.H.P.Ta., Protocolo de Pedro de Aragón, 1488 o 1489, fols. 1-26v.

Una cifra muy próxima arroja la suscripción, en el año 1481, de un censal por valor de 33.000 sueldos, firmado solidariamente por una aljama formada por 32 individuos. A.H.Prov.Z., Sección Casas Nobiliarias, Ducado de Hijar, (en proceso de catalogación).

$1776 i s$ A. Dioc. Z., Sección histórico-jurídica, Procesos criminales, 2/37, 1449, fol. 20.

178 Según un documento recientemente exhumado, a mediados del siglo XV comparecen con cierta regularidad a las convocatorias aljamiales un total de 31 representantes, to que en el caso de que todos fueran cabezas de familia, podria situar su población entre las 100 ó 120 personas. GómEz de Valenzuela, Maruel, «Ocho documentos sobre judíos del Bajo Aragón: Oliete, Huesa del Común, Belchite y Pina (1453-1545)», Teruel, 80-81 (1989-1990), pág. 102.

179 Arroja, según la pecha ordinaria de 1491, un montante de 25 ó 30 fuegos fiscales. REDONDO VEINTEMILLAS, Guillermo, «Fernando II y el régimen señorial en Aragón: la sentencia de Celada (1497)", Estudios/79, I (1979), págs. 23l-265.

IRo Cuenta con, al menos, 25 vecinos. DuRan Gudial, Antonio, La judería de Huesca, Zaragoza, 1984, págs. 91-95.

$|\not|$ Cuyo cernenterio es mencionado, aunque sin mencionar la fuente, en MARIN PadlLLA, Encarnación, "Nuevos datos sobre sinagogas y un cementerio judio en Aragón», Sefarad, XLVI[I (1988), págs. 426-428.

Hispminia, LVI/3, nủm. 194 (1996) 885-944 
justicia y oficial mayor de la Hermandad); Mallén ${ }^{182}$ (Carlos de Ixar, comendador). Causa sorpresa que se omita la populosa Almunia de Doña Godina ${ }^{183}$, o las localidades de Luna ${ }^{184}$, Biel ${ }^{185}$, Luesia o Albalate - sujetas a la mensa arzobispal de Zaragoza - o Sástago ${ }^{186}$

Por su parte, en Valencia se anotan los lugares del conde de Oliva, Almenar (conde de Aversa) y Moxén (Pero Maça de Liçana). En fin, Cataluña incluye las villas del duque de Cardona, marqués de Pallars y conde de Pradas, Perelada (vizconde de Rocaberti), Santa Coloma ${ }^{187}$ (mosen de Queralt), Sant Soloni y Ostalrich (almirante de Castilla) ${ }^{188}$.

En este contexto, procede recordarlo, según la siempre certera pluma de $\mathrm{M}$. A. LADERO, la población total de Aragón se elevaría a unos 257.000 habitantes 189; la de Cataluña a 303.000; la de Valencia a 250.000; y la de las islas Baleares a 55.000 190; entre tanto, BERNÁLDEZ, uno de los cronistas más fidedignos de la

182 La población judía — compuesta por un mínimo de trece familias, mayoritariamente dedicadas al sector textil (tejedores y sastres) - vive en el barrio de la usinogan, cuyo trazado debía ser un tanto indefinido por el elevado número de confrontaciones cristianas. A.H.P.B., Protocolo de Niguel Ezquerra, 1479, fol, $41 \mathrm{v}$.

18.3 Cuenta con un minimo de 77 varones mayores de edad, así como 46 casas, lo que se traduciría en 185-200 personas. Marin Padilla, Encarna, "Los judíos de la Almunia de Doña Godina, villa aragonesa de Señorío, en la segunda mitad del siglo Xv", Sefarad, Li (1951), pág. 328.

184 Donde, según un epistolario de 1409 , se percibian sisas sobre veinte fuegos judios. Agudo Periz, José Luis, «El señorío jurisdiccional de María de Luna. Un "Registro de Cartas" de 1409", Cuadernos de las Cinco Villas, 2 (1988), doc. 35.

185 Posee 70 varones con capacidad de obrar. Motts Dolader, Miguel Angel, «Los judíos de Biel en la Edad Mediar, Suessetania, 12 (1992), págs. 21-53.

${ }_{186}$ Nos consta que existía una judería bajo la jurisdicción del Conde de Sástago. A.H.Prov.Z., Sección Inquisición, leg. 22, núm. 5, 1497, fol. 10.

187 El exilio afectó, al parecer, a treinta familia. SECALL 1 GUELL, Gabriel, Les jueries medievals tarragonines (Aportació Històrica), Valls, 1983, pág. 304 y PtTA I MERCE, Rodrigo, «Aspectes de la població del Call de Santa Colomas, XVII Assemblea Intercomarcal d'Estudiosos, Aplec de Ponències $i$ Comunicacions, Santa Coloma de Queralt, 1979, págs. 85-101.

El primer autor citado elabora una lista nominativa integrada por 38 sujetos de derecho. SECALL 1 Guel., Gabriel, La Comunitat Hebrea de Santa Coloma de Queralt. Tarragona, Diputación, 1986, págs. 192-194.

188 Motis Dolader, Miguel Angel, La expulsión de los judios del Reino de Aragón, vol, I, págs. 188-190.

189 En el primer tercio del siglo podemos adelantar una cifra total para el Reino de Aragón, incluyendo las minorias, próxima a los 200.00 habitantes, mientras que el conjunto de los territorios de la Corona de Aragón, incluyendo Mallorca, sobrepasaría el millón. SARASA SÁNCHEZ, Esteban, Aragón en el reinado de Fernando (1412-1416). Gobierno y Administración. Constitución Politica. Hacienda Real, pág. 50.

Los fogajes de 1495 en Aragón arrojan un total de 51.540 fuegos muy desigualmente repartídos por 1.471 lugares. Serrano MonTalvo, Antonio, «La población altoaragonesa a fínales del siglo XV», Pirineos, 31-32 (1954), págs. 201-233 \& FALCON PérEZ, Isabel, «Aportación al estudio de la población aragonesa a fines del siglo XV», Aragón en la Edad Media, 5 (1983), págs. 255-302.

190 Ladero Quesada, Miguel Angel, España en 1492, Madrid, 1978, págs. 29-34.

Hixpania, LVI/3, nủm. 194 (1996) 885-944 
época, atribuye 6.000 hogares judíos a la Corona de Aragón ${ }^{191}$, con una estimación relativa de 170.000 personas en toda la Península ${ }^{192}$.

Según se desprende de nuestros propios cálculos - sujetos a criterios restrictivos y, en cualquier caso, susceptibles de ser revisados a la luz de nuevos hallazgos ${ }^{193}$-- los judíos residentes en el Reino de Aragón se encuentran próximos a las 8.000 ó 9.000 personas ${ }^{194}$. Si incorporamos los territorios peninsulares de la Corona, éstos se aproximan a los 10.000 ó 12.000 judíos ${ }^{195}$, un $1,2 \%$ del total, cuando en Castilla, con 70.000 efectivos ${ }^{196}$, se sitúan en torno al 1,6\% ${ }^{197}$.

191 Bernaldez, Andrés, Crónica de los Reyes Católicós don Hernando y doña Isabel, Biblioteca de Autores Españoles, vol. LXX, Madrid, 1953, pág. 652.

Este mismo número de fuegos es adoptado para Aragón por otros cronistas como Alonso Barrantes. Cit. Caro Baroja, Julio, Los judios en la España Moderna y Contemporánea, Madrid, Ediciones Istmo, 1978, pág. 199.

192 Asumido por BAER, Fritz, Historia de los judios en la España Cristiana, Madrid, Altalema Editores, 1981, pág. 791 nota 16. De igual modo, LóPEZ MARTINEZ, Nicolás, Los judaizantes castellanos y la Inquisición en tiempos de Isabel la Católica, Burgos, Publicaciones del Seminario Metropolitano, 1954, pág. 367.

l. Loeb asumía que la población sefardi de 1886 equivalía al grueso de los expulsados de 1492 , por to cual, desde su perspectiva, la Península estaría habitada por 235.000 judios, 150.000 de los cuales fueron bautizados y 20.000 murieron. LoEB, Jsidore, «Le nonbre des juits de Castille et d'Espagne au Moyen Age», Revue des Etudes Juives, XIV (1887), págs, 161-183.

193 KAMEN, Henry, «The Mediterranean and the expulsion of Spanish Jews in 1492», Past and Present, 119 (1988), pág. 30.

${ }_{194}$ Motis Dolader, Miguel Angel, La expulsión de los judios del Reino de Aragón, vol. 11 , págs. 304-309.

Según los datos tabulados sobre la demografía en páginas anteriores, que actualizan los de mi primera tesis doctoral, y teniendo en cuenta que se omiten necesariamente algunas colectividades cluyo peso especifico se desconoce, señalo a título ilustrativo algunas cuantificaciones mínimas: Zaragoza (1.840-2.070), Calatayud (550-650), Daroca (100-200), Tarazona (350-400), Borja (350), Teruel (295), Albarracín (100-200), Jaca (295-330), Huesca (540-600), Monzón (590-660), Ejea de los Caballeros (90-100), Tauste (70-100), Uncastillo (100), Sos del Rey Católico (120-135), Magallón (1 10-130), Husesa del Común (60-65), Oliete (45-55), Epila (170-190), Híjar (150-175), Pina de Ebro (100-125), Fuentes de Ebro (ca. 300), Ariza (100-135), Ayerbe (25), Mallén (50-60), Almunia de Doña Godina (185-200), Luna (80-90), Biel (150), Belchite (35-40), etc.

195 SuÁrez FernandeZ, Luis, Judios españoles en la Edad Media, Madrid, Rialp, 1980, Libros de Historia, núm. 2, pág. 272 nota 7.

Otros estudiosos la elevan, ałegando que tan sólo de los cinco contratos de fletamiento se demostraría el embarque de 7.500 personas, a las que habria que añadir las 2.000 de otras aljamas aragonesas y las valencianas de Sagunto y Játiva, máxime «si pensamos que faltan numerosas juderías de la Corona por conocern. Hinojosa MoNTaLvo, José, «Solidaridad judía ante la expulsión. Contratos de embarque (Valencia, 1492)», Saitabi, XXXI1l (1983), pág. 120.

196 Derivados de las 14.400 ó 15.300 familias sujetas a impuesto. SuÁrez FERnÁndez, Luis, Documentos acerca de la expulsión de los judios, Valladolid, 1964, pág. 56 y La expulsión de los judíos de España, Madrid, Mapfre, 1991, págs. 335-338.

En cualquier caso, según los cálculos más optimistas, una densidad inferior a 100.000 personas. LAdero QueSADA, Miguel Angel, «Los judios castellanos del siglo XV», en Judios. Sefarditas. Conversos. La expulsión de I592 y sus consecuencias, pág. 428 , y más recientemente, «El número de judios en la España de 1492: los que se fueron’ págs. 170-180

197 LADERO QUESADA, Miguel Angel, «Las juderías casteilanas según algunos "servicios" fiscales del siglo Xvm, págs. 249-64. 


\section{URBANISMO: TERRTTORIALDAD Y MEDIDAS REGLAMENTISTAS}

El ordenamiento jurídico medieval no prevé en todos sus aspectos la actividad de la Administración pública, contraponiéndose la actividad administrativa reglada y la discrecional. Cuando se produce el primer supuesto, se conoce con certeza la resolución que recaerá sobre un hecho dado, bastando con subsumirlo en la norma aplicable; por el contrario, cuando la actividad administrativa es discrecional, como sucede con las medidas urbanísticas adoptadas respecto a la minoría hebrea, no cabe efectuar esta previsión. Los diversos niveles de la Administración ejercen sus potestades con una finalidad distinta de la predeterminada por el ordenamiento, desviándose de aquélla e incurriendo, no pocas veces, en el vicio de desviación de poder y en la arbitrariedad, tendencia muy clara en los municipios cristianos, en continuo litigio con las aljamas y sus respectivos ámbitos jurisdiccionales. En su caso, el papel articulador y moderador de la Corona es ineludible para mantener el statu quo ${ }^{198}$.

La segregación espacio-funcional - la alteridad ${ }^{199}$ - configura uno de los puntos indeclinables y programáticos del poder político, en el siglo XV de manera singular, una vez que se impone la corriente canónica - Gregorio $X$, que no admite la presencia judía sino desde una perspectiva de pura marginalidad, recomienda en 1275 a Jaime I la necesidad de establecer barrios muradosn ${ }^{200}$-, codificándose, bajo una superficie de tutela, como un poderoso instrumento de dominación ${ }^{201}$, de unos sujetos que no alcanzan la condición

19x MOTIS DOLADER, Miguel Angel, Ordenamiento jurídico de las comunidades judias en Aragón en la Edad Media (siglos XII-XV), op. cit.

192 ARKEL, Dik van, «The growth of the anti-Jewish stereotype. An attempt ar a hypotheticaldeductive method of historical researchs, International Review of Social History, 30 (1985), págs. 270-305; GuiDot, Bernard, "L'image du juif darns la geste de Guillaume d'Orange», Revue des Études Juives, 137 (1978), págs. 3-25; KRIEGEL, Maurice, «Un trait de psychologie sociale dans les pays méditerranéens du Bas Moyen Age, Le juif comme intouchable», págs. 326-330; MENACA, Marie de, "Mythe et réalité dans la vision du juif au Moyen Age dans les royaumes chrétiens d'Espagne», en Actes du 106e Congrés national des Sociétés savantes, Perpignan, 1981, Section de philologie et d'histoire, págs. 235 53 .

Este proceso de «fosilización» no tardará en hacerse extensivo a los conversos. CiCERI, MarceIla, «Lo smascheramentos del "converso" e i suoi stereotipi nei canzonieri spagnoli», Miscellanea di studi in onore di aurelio Roncaglia, Modena, Mucchi Editore, 1989, vol. I1, págs. 435-50; Rose, STANLEY E., "Anti-semitism in the "cancioneros" of the fifteenth century: the accusation of sexual indiscretions», Hispanófila, 26 (1983), págs. 1-10; MECHOULAN, H., "L'alterité juive dans la pensée espagnole (1550-1650)m, Studia Rosenthaliana, 8 (1974), págs. 171-204; LAIN ENTRALGO, Pedro, Otreidad y projimidad, vol. II, Madrid, 1961; BENITO RUANO, Eloy, "Otros cristianos», Encuentros en Sefarad, Instituto de Estudios Manchegos, Ciudad Real, 1987, págs. 253-64 y MENACHE, Sophie, "Les Hebreux du XIV ${ }^{e}$ siècles; la formation des stéréotypes nationaux en France et en Angleterre", Ethnopsychologie, 35 (1980), págs. 55-65.

200 CANELlas López, Angel, "Zaragoza hace 700 antos», Las Españas del siglo XIII, Zaragoza, 1971 , pág. 106.

201 KrieGel, Maurice, Les juifs à la fin du Moyen Age dans la Europe Mediterraneénne, Paris, Hachette, 1979, págs. 20-28.

Hixpania. LVI/3, núm. 194 (1996) 885-944 
de "naturales", porque la religión se entiende como un factor modificativo de la capacidad en sus derechos políticos ${ }^{202}$. La segregación es un instrumento de dominación bajo una apariencia protectora ${ }^{203}$.

El código urbanológico, entendido como irreversible, comporta la ruptura de vínculos entre la población cristiana -conversa, en un primer planteo ${ }^{204}$ y la judía ${ }^{205}$. El confinamiento en zonas reservadas se consolida, al propio tiempo que su arquetipo socio-antropológico ${ }^{206}$, contribuyendo a hacer más fácil su extirpación, imposible de llevarse a efecto si los contornos físicos y los conceptuales fueren difusos, como acontece con los conversos, infiltrados en todas las capas sociales y dotados de una gran capilaridad; las disposiciones que la regulan aceleran el paso de un estado antijudío latente a otro práctico - con la ruptura mental que ello implica ${ }^{207}$-, donde la coexistencia constituirá el pórtico de la disgregación ${ }^{208}$. El aislamiento fosiliza las estructuras, perjudica la calidad de vida e incrementa su marginación en la constantes macroeconómicas y políticas, acrecentando su "subsidiariedad", paso previo a su disectomía del cuerpo social ${ }^{209}$. A su vez, una mayor dependencia del rey debilita los vínculos extracomunitarios.

Estos paradigmas edifican un sistema donde los contactos entre judíos y no judíos son relativamente raros, aparte de los estrictamente económicos. El barrio judío delimitará un espacio impenetrable para el cristiano y sembrará el recelo, la desconfianza y el desconocimiento. La demarcación espacial representa un aspecto privilegiado de esta segregación. La imagen del judío desempeña una función en el complejo de relaciones entre el grupo dominante y la comunidad subordinada: estabiliza enteramente el statu quo obtenido, generando un arquetipo de inferioridad e indignidad. Joel Ibn Sha'aib, predicador judío en Zaragoza, a fines del siglo xv, constata que para el populacho "los judíos son el ejemplo de todo mal», los reyes y los artesanos -dice- se muestran aquiescentes y se abstienen de reprender este juego de invectivas ${ }^{210}$.

202 Motis Dolader, Miguel Angel, «Contexto jurídico de la expulsión: el problema del status y la naturaleza», op. cit. $20-28$.

203 KRIEgel, Maurice, Les juifs à la fin du Moyen Age dans la Europe Mediterraneénne, págs.

204 Lo que proyecta una nueva situación. Romano VentuRA, David, «Coesistenza/convivenza tra ebrei e cristiani ispanici», Sefarad, LV (1995), pág. 374.

205 HeErs, Jacques, Le clan familial au Moyen Age, Paris, Presses Universitaires de France, Collection Hier, 1974, págs. 173.176.

206 MOTiS DOLADER, Miguel Angel, «Medidas reglamentistas y segregación de las juderías de la Corona de Aragón en la Baja Edad Media», VIII Convegno Internazionale. La deriva del continenti architettura e urbanistica andalusa dopo il 1492, Roma, Dpto. di Architettura e Analisi della Cità, Università degli Studi di Roma "La Sapienza", 1992 (en prensa).

207 Romano Ventura, David, “Coesistenza/convivenza tra ebrei e cristiani ispanici», pág. 377.

208 MONSALVo, José Maria, Teoría y evolución de un conflicto social. El antisemitismo en la Corona de Castilla en la Baja Edad Media, Madrid, Siglo XXI, 1985, pág. 135.

209 Motis Dolader, Miguel Angel, «Qujebra de la estructura multiconfesional en la Corona de Aragón y el nacimiento del "Estado Moderno"

210 BEN SASSON, H. H., "La génération de l'expulsion d'Espagne sur elle-même», Zion, 26 (1961), pág. 26. 
El urbanismo actuará como reactivo materializador de estos principios teóricos o como verdadero "laboratorio de pruebas» ${ }^{211}$. Si en sus orígenes la judería fisonómica, orgánica y urbanísticamente nace como principio de autoafirmación de una identidad y como protección frente a agresiones externas, ahora padece el rechazo de la sociedad circundante, en un movimiento de doble sentido en que triunfa la "territorialidad sanitaria", muerte de la interrelación y de la "anexionabilidad».

La judería nunca poseyó un modelo territorial definido y una estructura general orgánica en el sentido moderno del término, sin embargo, existe un determinado grado de especificidad funcional: el residencial privado, el cívico-religioso y socio-asistencial, y el comercial, incluido el abastecimiento alimentario ${ }^{212}$, muy condicionado por las normas segregacionistas ${ }^{213}$.

La sinagoga -ayuna del sentido sacral atribuido a los templos cristianos- donde se formalizan buena parte de los tratos comerciales testificados ante el çofer ${ }^{214}$-o meros acuerdos verbales- bajo la juramentación instrumental toráhica, se convierte en un ágora mercatorum. Además de ser el lugar donde se congrega la aljama, se protocolizan en esta sede buena parte de los asuntos económicos relacionados con las finanzas comunitarias o con las transacciones individuales ${ }^{215}$. En este eje rector se congregan edificios de profunda significación como son, además de la sinagoga, el hospital, las cofradías asistenciales, la residencia del rabino, etc., elevándolo a la categoría de centro político-social y engranaje cohesionador de la comunidad. Además de la concurrencia de los edificios más relevantes guardan vecindad allí las familias más acomodadas y prestigiosas ${ }^{216}$. La plaza de la judería, en fin, es el meso-espacio - con aforo suficiente para todas las familias que alberga- escogido para patentizar las manifestación lúdicas - juegos infantiles ${ }^{217}$ - y luctuosas ${ }^{218}$.

Esta sintaxis del tejido urbano, que introvierte a los judíos en recintos ad hoc, se articula orgánicamente bajo la potestad legislativa de los Reyes Cató-

\footnotetext{
211 Motis Dolader, Miguel Angel, Los judios en Aragón en la Edad Media (siglos XII3-XV), págs. 53-65.

212 Motis Dolader, Miguel Angel, «Régimen alimentario de las comunidades judías y conversas en La Corona de Aragón en la Edad Media», págs. 273-292.

213 Motis DOLADER, Miguel Angel, «Líneas programáticas de la legislación sobre judios y judeoconversos en el reino de Aragón en la segunda mitad deł siglo XV), en El final de la convivenvia: judios y conversos en la Península (I391-J492), Sevilla, 1991, (en prensa).

214 Cfr. Blasco, María Asunción, «Notarios-escribanos judios de Aragón (siglos XIV-XV)», Rashi 1040-1990. Hommage à Ephraìm E. Urbach, Paris, 1993, 647-654.

215 A.H.P.Z., Protocolo de Antón de Aviego, 1481, fol. 1 \& 1471, fols. 37-39.

216 Morts Dolader, Miguel Angel, «Ordenamiento urbanístico de la judería de Daroca: morfología y funcionalidad», Aragón en la Edad Media. Estudios de Economía y Sociedad, IX (1990), págs. 137.178.

217 A.H.Prov.Z., Sección Inquisición, 14/3, año 1489, Testificación de Todroz Argilet, judio, mercader, habitante en Huesca, fol. 16v.

218 HeERS, Jacques, El clan familiar en la Edad Media, Barcelona, 1978, pág. 188.
}

Hispaniı, LVI/3, núm. 194 (1996) 885-944 
licos, que plasman su programa segregativo en las Cortes de Toledo de 1480, donde, en evitación de la influencia que los judíos ejercían sobre los cristianos nuevos, se acordó que en el plazo de dos años toda la población hebrea debería ser recluida en barrios definidos y delimitables, alegando, como principio doctrinal, "[que] de la continua conversacion e uiuienda mezclada de los judios e moros con los christianos resultan grandes dannos e inconuenientes, e los dichos procuradores sobre esto nos han suplicado mandassemos proueer, ordenamos e mandamos que todos los judios e moros... destos nuestros reynos... tengan sus juderias e morerias distintas e apartadas sobre si, e no moren a vueltas con los christianos, ni ayan barrios con ellos... cumpla dentro de dos annos contados desde el dia que fueran publicadas e pregonadas estas nuestras leyes.... ${ }^{219}$. Los soberanos se limitaron a designar a los oficiales que, de común acuerdo con las poblaciones interesadas y afectadas por la reglamentación, establecieran los dominios y linderos de estos asentamientos, garantizando que cumplieran unos mínimos dignos de habitabilidad. Este acuerdo señala el triunfo de los medios eclesiásticos que rodean a los soberanos y un reconocimiento tácito de lo impracticable - y quizás indeseable- - de la atracción de los conversos incorrectamente asimilados hacia la ortodoxia ${ }^{220}$.

Aunque las disposiciones toledanas se adscribían prioritariamente a la Corona castellana, su influjo no pasó desapercibido en Aragón, bajo un efecto simpático y osmótico. Con la férula inquisitorial o sin ella, las más importantes ciudades rivalizaron entre si para su cumplimiento, intentando ostentar fidelidad hacia sus señores, a veces con exceso de celo ${ }^{221}$. No en vano, habían sido aplicadas prematuramente, mucho antes de que se aprobaran en el concillium toledano, con desigual fortuna ${ }^{222}$.

En Aragón -donde un buen número de sus juderías no estaban sujetas a concreción delimitativa- no significaban sino la actualización y puesta en marcha de las ideas de Vicente Ferrer, recogidas con fidelidad en la bula de Benedicto XIII, paradigma referencial de las claves interpretativas de la politica hacia los judios en el resto de la Edad Media: «en sus ciudades, villas y lugares donde moran judíos, fijen ciertos límites, fuera de los cuales no les se permitido habitarn ${ }^{223}$.

Esta actuación, basada a priori en postulados religiosos, ampara motivaciones menos confesables como apetencias de suelo edificable, competencia gremial, aumento de la ingerencia en la anatomía de las aljamas en beneficio de los ayuntamientos.... Este máximo religioso no será reasumido por el alto

219 Cortes de los antiguos Reinos de León y de Castilla, Madrid, Real Academia de la Historia, 1861-1903,vol. IV, pág. 149.

220 SuÁrez FERnÁndez, Lais, Documentos acerca de la expulsión de los judíos, pág. 24.

221 SuÁrez Fernández, Luis, Documentos acerca de la expulsión de los judíos, págs. 34-35.

222 En 1274 se dicta auto de confinamiento de los judios ovetenses. RUIZ DE LA PENA, J. I., «La sociedad ovetense en el siglo XIIl», Hispania, 1967, pág. 5.

223 AMADOR DE Los Rios, José, Historia Social, política y religiosa de los judíos de España y Portugal, Madrid, 1875-76, vol. II, págs. 640-41. 
estamento eclesial del Papado - -se encuentra en el solio pontificio el Papa Sixto IV ${ }^{224}$ - hasta cuatros años después de su promulgación ${ }^{225}$. El criterio inquisitorial tiene un papel impulsor incuestionable ${ }^{226}$, existiendo una relación causativa con el establecimiento del Tribunal del Santo Oficio ${ }^{227}$.

Los principios de la desvinculación espacial pueden expresarse a modo de silogismo: la herejía judaizante gangrena las fibras de las nuevas generaciones de conversos, de modo muy especial de los catecúmenos; el proselitismo auspiciado por sus antiguos correligionarios judíos se comporta como un organismo íncubo que propicia continuas recaídas en la fe abjurada; la profilaxis debe resolverse en los siguientes términos: un drástico apartamiento físico sin paliativos bastará para que, una vez aislado el fómite contagioso, consiga que la epidemia endémica se extinga por la propia inoperatividad de los agentes causantes de su desencadenamiento.

Digamos, en fin, que ocasionalmente era la sociedad de cristianos viejos la que se mostraba contraria a esta asimilación. Los propios inquisidores son conscientes de este rechazo. En Huesca exhortan a los jurados para que «la cíudat diesse una casa franca a cristianos nuebos que se havian fecho porque no tenian donde estar. La respuesta es refractaria hacia esta reconvención porque "la ciudat estaba en necessidat, que no se diesse casas ningunas a los dichos christianos nuebos que costasse cosa alguna a la ciudat" ${ }^{228}$.

Bajo cualquier circunstancia la puesta en marcha de esta providencia suscitó un sinfin de dificultades, enconos y enfrentamientos entre la cristianos y judíos respecto a los derechos mutuos adquiridos. Los problemas eran más o menos virulentos, dependiendo de si se trataba de una reubicación o de la

224 Ya lnocencio IIl, bajo el paradigma del Papado como «caput et fundamentum Christianitatis» establecerá el postulado de la «spiritualis plenitudo», HAGENEDER, Othmar, «Mandatum und Praeceptum im politische Handeln Papst Innocenz' III», en Proceedings of the Sixth International Congress of Medieval Canon Law, Città del Vaticano, 1985, pág. 378.

225 LLORCA, Bernardino, Bulario pontificio de la Inquisición española, Roma, 1944, págs. 106-7.

226 A.C.A., Real Cancillería, Reg. 3 684, fol. 33. Pub. BAER, Fritz, Die Juden im Christlichen Spanien. Erster Teil: Aragon und Navarra, vol, I, doc. 562, págs. 912-13.

227 Centrémonos en la pequeña aldea turolense de Cella, a algunos kilómetros de la ciudad de Teruel, donde se congregaban algunos grupos significativos de judíos. Careciendo de un lugar apartado ad hoc se promulga la inmediata e irrecusable evacuación. Se concede un plazo de ocho días para su estricta observancia: «... no haviendo en el dicho lugar juderia, ni apartado donde los dichos jodios esten e habiten, sino con los christianos, e que por la participacion e conversacion dellos se han seguido y speran seguir grandissimos danyos en offensa de la divina majestat e damnacion de las almas de los christianos, por ende, a honrra y gloria de nuestro senyor Jesu Christo, e a enxalçamiento de la Sancta Fe Catholica, con tenor de la presente nuestra pragmatica... statuimos y ordenamos que dentro tiempo de ocho dias despues que la presente nuestra provision sera en el dicho logar publicada... todos los jodios que viven y moran en el dicho logar de Cella, se vayan y absenten de aquell e de aqui adelante no esten ni puedan estar ni habitar en todo el dicho logar de Cella ni en parte del de hun dia natural adelante». Floriano, Antonio, «El tribunal del Santo Oficio en Aragón. Establecimiento de la Inquisición en Teruelm, Boletín de la Real Academia de la Historia, LXXXXVI (1925), págs. 544 y ss.

228 A.M.H., Actos Comunes, ms. J6, 1489, fol. 36.

Hispania, LVI/3, núm. 194 (1996) 885-944 
reconsideración espacial sin traslado total de su antiguo emplazamiento. Las autoridades zaragozanas, a cuya cabeza se sitúa el prior de la Seo metropolitana, mosén Miguel Ferrer, aprovechando la lugartenencia de Isabel I ${ }^{229}$, obligó a los judíos a recluirse en el interior de la judería murada, en un plazo impracticable de treinta días, sumándose prescripciones indumentarias ${ }^{230}$ y gremiales ${ }^{231}$. A su regreso, el rey exigió una retractación pública, en abierta disconformidad con la lenidad y tibieza de su Consejo de Estado ${ }^{232}$, pudiendo recaer sobre los inspiradores una pena de cincuenta azotes o, en situaciones límite, la muerte ${ }^{233}$.

El cercamiento de la judería Nueva o de Barrio Nuevo despertaba impedimentos técnicos, díficiles de soslayar, aunque en las embocaduras de sus siete callizos se instalaron sendas puertas o trenques, que impedían su acceso en las horas nocturnas o en ciertas festividades cívico-religiosas ${ }^{234}$. Más factible resultaba la depuración de la colindancia de viviendas. Así se explica que, el 17 de octubre de 1483, Mossé Abuzmel alias Chamorro, en cumplimiento de lo preceptuado por el baile, el merino y los jurados de Zaragoza, enajene a un zurrador cristiano unas viviendas en los callizos de la judería, confrontantes con su domicilio ${ }^{235}$.

Los mismos problemas de convivencia plantean los jurados de Huesca, quienes juzgan insostenible y en «deservicio de Dios» que «que las puertas [de las casas de los judíos que] salen al Coso de la dita ciudat los dichos dias (las Pascuas, Domingos, el día de Nuestra Señora "et otras fiestas solepnes") «tienen abiertas, paseando los dichos judios por el dito Coso...». El asunto se endosa, en 1491, a los jurados y procuradores de la ciudad, entendiendo también en ello los inquisidores, promulgándose reglamentaciones constrictivas ${ }^{236}$ y prohibiéndose el hábitat intercalar ${ }^{237}$. Los jurados de la villa de Tortosa,

229 Gobernadora y administradora de los reinos de la Corona de Aragón -corregentem, gubernatricem- desde 1481. TORRE, Antonio de la, «Isabel la Católica "corregente" en la Corona de Aragón», Anuario de Historia del Derecho Español, XXIIl (1953), págs. 424.

230 LALINDE ABADIA, Jesús, «La indumentaria como símbolo de la discriminación jurídicosocial», Anuario de Historia del Derecho Español, LII (1983), págs. 595-99.

231 A.C.A., Real Cancillería, Reg. 3 562, fol. 84v. Pub. BAER, Fritz, Die Juden im Christlichen Spanien. Erster Teil: Aragon und Navarra, vol. I, doc. 554 págs. 897-98.

232 A.C.A., Real Cancillerí, Reg. 3 562, fol. 85. Pub. BAER, Fritz, Die Juden in Christlichen Spanien. Erster Teil: Aragon und Navarra, vol. I, doc. 554 págs. 899-900.

233 A.C.A., Real Cancillería, Reg. 3 562, fol. 91.

234 Motis Dolader, Miguel Angel, «Los judios zaragozanos en la época de Fernando Il de Aragóny, en Minorités et marginaux en Espagne et dans le Midi de la France (VII. ${ }^{\circ}$-xvil. ${ }^{\circ}$ Siècles), Paris. C.N.R.S., 1986, pág. 396.

235 A.H.P.Z., Prolocolo de Antón Maurán, 1483, fols. 76-76v.

236 A.M.H., Actos Comunes, ms. 18, 1491, fol. 22v.

Los problemas nacidos de la confrontación de casas de judíos, judeoconversos y cristianos entre sí, avivarán los conflictos. Sin ir más lejos, en el año 1483 se cruzarán una serie de misivas al baile y al merino para subsanar diferencias nacidas en su seno. A.C.A., Real Cancilleria, Reg. 3562 , fol. 124-124v.

237 En el ámbito de este decenio, las Cortes navarras reunidas en Estella en 1488, como si de corifeos del cónclave toledano se tratare, obligan a los judios de las merindades de la Ribera a que se congreguen en torno a sus respectivas sinagogas, sin intercalarse con las viviendas cristianas. LEROY, Béatrice, The Jews of Navarre, Jerusalem, 1985, pág. 145. 
asimismo, activan en 1489 unas ordinaciones en desuso, en virtud de las cuales las juderías debran estar dotadas de sistemas de cierre periférico ${ }^{238}$.

\section{EL PODER POLÍTICO DE LAS ALJAMAS: EL IMAGINARIO SOCIOLÓGICO 239}

El Derecho hispánico en relación a las clases sociales, se basa en el principio de la personalidad, aplicado sobre los elementos no cristianos de la población, a los que se concede un grado de aptitud distinta; es la proyección estrictamente religiosa en el campo de la sociedad y en el de los derechos locales ${ }^{240}$. Los judíos tienen, en general, una estimación y consideración sociojurídica superior a los moros, llegando a alcanzar un plano de igualdad relativa con el cristiano, en franca regresión desde la Baja Edad Media ${ }^{241}$.

En la época analizada, hemos de subrayar el protagonismo de las clases medias - artesanado y profesiones liberales ${ }^{242}$ - gracias a la implantación del sistema de la insaculación en los cargos electivos de gobierno - frente a la cooptación que permitía la perpetuación de las mismas familias- y a una mayor organización en sus reivindicaciones políticas, a la par que un relevo generacional y la conversión de las clases dirigentes de antiguo cuño. Las tareas de gobierno, en un principio monopolizadas por un número reducido de familias, pasaron a ser patrimonio de la aljama, permitiendo el acceso a los componentes de los tres grupos socioeconómicos, a pesar de los impedimentos puestos por los antiguos detentadores del poder ${ }^{243}$, tendiendo, además, hacia una más justa redistribución de las cargas fiscales ${ }^{244}$.

El núcleo jurídico de la comunidad se funda en los dictados del Talmud ${ }^{245}$ y la Torah, las ordinaciones o taqqanôt -debatidas y aprobadas por la aljama,

238 SECALL ] GUELL, Gabriel, Les jueries medievals tarragonines (Aportació Històrica), pág. 515 y CARRERAS CANDI, Francesc, L'aljama de juheus de Tortosa, págs. 111-114.

239 El «imaginario sociológico» del ente social puede conjugarse como «un momento de cooperación y solidaridad», «un sistema de jerarquía» o «un momento de integración y de unidad». CostA, Pietro, en Lo Stato Immaginario. Metafore e Paradigmi nella Cultura giuridica italiana fra Ottocento e Novecento, Milano, Giuffrè Editore, s.a. vol. 2I, págs. 48-64.

240 MAYER, Ernest, Historia de las instituciones sociales y políticas de España y Portugal durante los siglos v al XIV, Aalen, Scientia Verlag, 1991, Reimp. Madrid, 1925, pág. 313.

241 GARCiA ULECIA, Alberto, Los factores de diferenciación entre las personas en los fueros de la Extremadura castellano-aragonesa, Sevilla, Anales de la Universidad Hispalense, Publicaciones de la Universidad de Sevilla, 3975, pág. 214.

242 Motis Dolader, Miguel Angel, «Socio-economical Structure of the Aljamas of the Aragon Kingdom (1391-1492)», op. cit.

243 Cfr., a título comparativo, el régimen competencial de las aljamas germanas medievales. SpITzER, Schlomo, «Die jüdische Gemeinde im Mittelalter: Institutionen, Kompetenzer und Aufgabe», Kairos, 21 (1979), págs. 48-59

244 A.C.A., Real Cancillería, Reg. 3 116, fols. 72-74v. \& Motis DOLADER, Miguel Angel, «Régimen fiscal de las comunidades judías de Aragón en la Baja Edad Media: la aljama de Huesca en el siglo XIV), op. cit.

Hispaniu. LVI/3, ıúm. 194 (1996) 885-944 
pero promulgadas y confirmadas por el monarca regnante-- y la normativa privativa de la Corona que les dispensaba un importante marco legal, a la vez que las hacía más vulnerables, al depender del favor de quien se ciñera el cetro del poder en un momento determinado ${ }^{246}$.

Desde la segunda mitad del siglo xIV se gestará una nueva organización aljamial que permitirá la cristalización de los tres organismos primordiales de gobiemo colegiado: la asamblea plenaria, el consejo y el comité ejecutivo. También se consolidan los cargos relacionados con la administración y percepción de impuestos (clavarios, tasadores, recaudadores...); la impartición de justicia y los que requerían conocimientos talmúdicos (jueces, notario, albedín); agentes ejecutivos (andadores, porteros); socio-religiosos (rabinos ${ }^{247}$, shamas, shoet), etc.

\subsection{Soberanía y jurisdicción}

Como los judíos no eran capaces de garantizar su seguridad sin el apoyo del monarca reinante, la legalidad en el acatamiento del poder constituido, ya desde los primeros estadios medievales ${ }^{248}$, era el único principio político que permitía su permanencia como comunidad ${ }^{249}$ y el mantenimiento de elementos de Derecho penal y civil propios ${ }^{250}$. La salvaguarda de la integridad de su herencia espiritual, de cuando el pueblo constituía un Estado soberano ahora extraterritorial ${ }^{251}$, comportaba su lealtad como vasallos ${ }^{252}$.

245 A este propósito es vital la recopilación de Josef Caro de Toledo (1481-1575) publicada bajo el título Sulham Aruh. KLEIN, I., BLUMENTHAL, A. H. y Fink, L. "The Sulchan Arukh after 400 years; a conservative approach», Proceedings of the Rabbinical Assembly, Philadelphia, 32 (1968), págs. 36-71.

El judaísmo preservó su carácter «nomotético». KeLleY, Donald R., The Huntan Measure. Social Thought in the Western Legal Tradition, London, 1990, págs. 67-68.

246 Motis DOLADER, Miguel Angel, Ordenamiento jurídico de las comunidades judías en Aragón en la Edad Media, op. cit.

247 Adviértase que puede tener acepciones muy diversas. NIRENBERG, David, «A female rabbi in fourteenth Century Zaragozan, Sefarad, LI (1991), pág. 180.

248 Motss Dolader, Miguel Angel, «Contexto histórico-juridico de los judíos del Reino de Aragón (siglos. XI-XII): pluralidad normativa y preconfiguracion de las aljamas», en Estudios sobre Pedro Alfonso de Huesca, Huesca, 1996, págs. 56-72.

249 KRIEGEL, Maurice, Les juifs à la fin du Moyen Age dans le Europe Mediterraneénne, pág. 208 y Rakefet-Rothkoff, Aaron, «Dina D'Malkhuta Dina-The Law of the Land in Halakhic Perspective», Tradition, 13 (1972), pág. 6.

${ }_{250}$ Rav Dimi llegó a determinar que cuando un edicto real contra el judásmo entrara en vigor «uno debe incurrir en martirio, antes que transgredir e] más mínimo precepto». [Sanhedrin, 74a-b]. La situación extrema del martirio es requerida como medio de no incurrir en la idolatría, ciertas formas de aberración sexual -incluyendo el incesto y el adulterio-y el homicidio. BLEICH, J. D., «Judaism and natural law», Jewish Law Annual, 7 (1988), pág. 12.

251 DiAZ EsteBAN, Fernando, «Aspectos de la convivencia jurídica desde el punto de vista judio en la España Medieval», Actas del II Congreso Internacional Encuentro de la Tres Culturas, Toledo, 1985, pág. 107.

252 El profeta Jeremias, en su epistola a los judíos exilados en Babilonia, escribe: «procurad Ja prosperidad de la ciudad a donde os he deportado y rogad por ella a Yaveh, pues su prosperidad será vuestra prosperidad). Jeremías, 29:7. 
En el discurso iuris-histórico de una soberanía «acápite», los juristas hicieron frente a esta situación mediante la acuñación del aforismo talmúdico dina' de-malkuta', dina' _- kla ley del reino [el gobierno no judío], es ley»_ ${ }^{253}$, cuyo corolario esgrime que hay que acatar la ley del país donde se vive - - es preceptiva esta adhesión para obtener el permiso de residencia- ${ }^{254}$. De hecho, en muchas instancias, el sistema legal no judío actúa como una extensión de la halakha, debido a la recognición de este axioma ${ }^{255}$.

$A$ priori, existía una gran dificultad para los judíos que vivían en un Estado extranjero ${ }^{256}$ y deseaban ser leales a las leyes regnícolas y a los principios jurídicos de su propia $\mathrm{fe}{ }^{257}$. Era necesario realizar algunas adaptaciones y concesiones limitadas al derecho civil, donde se provee un modus vivendi 258 ; el impulso básico para este ajuste fue claramente polf́tico, no jurídico ${ }^{259}$.

Maimónides efectúa una de las más finas distinciones intelectuales entre la "ley del reino" y la "ley del rey". Por la primera entiende el ordenamiento jurídico del país conforme con su historia y sus tradiciones; la segunda es el capricho del rey y, por tanto, la tiranía que cae fuera del aforismo legal ${ }^{260}$. Se consideraba que correspondían al rey materias tales como la construcción de caminos y la fijación de los impuestos, pero no las referentes al matrimonio o al repudio, ni tampoco asuntos entre judíos, que habían de resolverse según la ley de éstas. No obstante, se verifica una paulatina incorporación del ordenamiento estatal al judío, convirtiéndose en parte integral de éste último ${ }^{261}$

La tendencia de la jurisprudencia aboca hacia la sumisión a las leyes territoriales. En los casos criminales la ley judía está prácticamente sometida a la autoridad real, siendo desposeídos en los primeros estadios medievales de

253 Sanhedrín, 20b.

254 ATLAS, Samuel, «Dina d'Malchuta delimited», Hebrew Union College Annual, 46 (1975), pág. 274 .

255 La ley civil no es heterónoma, ya que el consenso social enviste a la jurisdicción del Estado con la condición de ley autónoma. En consecuencia, la adopción de una ley civil no implica la abdicación de la autonomía de la ley judia, sino más bien su confirmación. El Talmud y las autoridades rabínicas medievales tratan de armonizar la ley civil con la vida cotidiana, tomando cognición de la ley pública. Tan sólo en el ámbito de lo puramente religioso salvaguardaron cualquier intrusión, en el resto mantuvieron una actitud liberal y versátil. ATLAS, Samuel, «Dina d'Malchuta delimited», pág. 273.

256 En principio, no se aplica en el Estado de Israel. Nedarim, 28 a.

257 ATLAs, Sarnuel, «Dina d'Malchuta delimited», pág. 270.

258 LANDMAN, Leo, "A further note on "the law of the kingdom is law"», Jewish Journal of Sociology, 17 (1975), pág. $37 \mathrm{y}$ «Law and Conscience: The Jewish View», Judaism, 18 (1969), págs, 17-29.

259 BLIDSTEIN, G. J., «A note on the function of "the law of the kingdom is law" in the medieval Jewish community», Jewish Journal of Sociology, 15 (1973), págs. 213-14.

260 Nachmánides también añade entre los requisitos testrictivos la exigencia de que los estatutos y tradiciones legales — para ser válidos o de obligado cumplimiento- deben haber existido en el territorio durante generaciones. RAKEFET-RoTHKOFF, Aaron, «Dina D'Malkhuta Dina-The Law of the Land in Halakhic Perspectiven, págs. 10-11.

261 Atzas, Samuel, «Dina d'Malchuta delimited», pág. 270.

Hispania, LVI/3, ním. 194 (1996) 885-944 
jurisdicción en la aplicación de la pena capital ${ }^{262}$, no sucediendo lo mismo en lo civil ${ }^{263}$. En todo caso, el principio dina' es operativo sólo si las demandas o exigencias de gobierno son justas ${ }^{264}$; si son discriminatorias, o entrañan violencia o robo no obligan ${ }^{265}$, a la luz de un tácito "contrato social» ${ }^{266}$.

\subsection{Estructura colegiada de poder y gobierno}

Como medio de control constitucional de las leyes — concibiendo la aljama como persona jurídica que actúa a través de órganos- se dota de realidad la configuración de corpora orgánicos dotados de una determinada competencia y sujetos a ciertos límites, muy distante de una estructura piramidal del ordenamento ${ }^{267}$.

Los judíos adoptan pronto dos principios básicos en la regulación de su convivencia política, emulando a los cristianos ${ }^{268}$ : el acatamiento de las decisiones adoptadas por la mayoría - simple o cualificada- del cuerpo social; y el reparto de las funciones que imponía la propia estructura político-social, lejana de un régimen asambleario, inorgánico e inespecífico, desde el punto de la transmisión y coparticipación del poder, en dura pugna con la oligarquización. Este fenómeno es de signo recíproco ${ }^{269}$.

Pese a que nos refiramos a la aljama como una persona jurídica, de hecho, es concebida a imagen y semejanza — «res analógica»- de una persona física o, en expresión ciceroniana, "personam civitatis" - la gestión de los magistrados-. En la Edad Media se halla más próxima de las nociones de "persona ficta" $\mathrm{y}$ "persona representata" equivalente a un "corpus universitatis" 0 "corpus morale et politicum» que, en el terreno bíblico, desemboca en una suerte de «communitas politica vel mystica» 270 .

262 Aboda Zara, 71 .

263 Baba Qamma, 84b.

264 Se aplicaría una fórmula similar al «obedézease pero no se cumpla». GoNZÁlez ALONSO, Benjamin, «La fórmula "obedézcase, pero no se cumpla" en el Derecho castellano de la Baja Edad Median, Anuario de Historia del Derecho Español, L (1980), págs. 469-87.

265 SOHET, David Menahem, The Jewish Court in the Middle Ages Studies in Jewish Jurisprudence according to the Talmud, New York, 1931, pág. 116.

266 ATLAS, Samuel, «Dina d'Malchuta delimited», pág. 272.

267 KeLsEN, Hans, Teoría General del Derecho y del Estado, 1945, Ed. Comunità, págs. 125 y ss. \& «Le garantie jurisditionnelle de la Constitution (La Justice Constitutionelle)», Revue de Droit Public, XIV, págs. 198-257.

268 Esta influencia es extensible y reversible, en principio, a todos los ámbitos de la vida colectiva, como son las costumbres y usos religiosos. GUTMANN, Joseph, "Christian influences on Jewish custums», Spirituality and Prayer, Jewish and Cristian Understandings. Ed. by Leon Klenicki Gabe Huck, New York, Paulist Press, Studies in Judaism and Christianity, 1983, págs. 128-138.

269 Grabols, Aryeh, «Remarques sur l'influence mutuelle de l'organisation de la communauté juive et de la paroisse urbaine dans les villes entre le Rhin et la Loire à la veille des Croisades», Civilisation et Société dans l'Occident médiéval, London, 1983, págs. 546-558. Reproducido en Atti della sesta Settimana Internazionale di Studi, Mitan, 1977.

270 SuAREZ, Francisco, De Legibus, 1, cap. VI, \$18. 
En la época talmúdica la comunidad al constituirse como ciudad era considerada una unidad corporativa, en cuyo bene' ha-ir los habitantes eran conceptuados como socios, y en la que cada uno tenía un status jurídico individual ${ }^{271}$. En la Edad Media es la comunidad la que tenía un status juridico, y no sus residentes; aquí no son contemplados como socios en una empresa común, sino individuos unidos por un deber de lealtad o fidelidad a la comunidad como un todo ${ }^{272}$, interactuando a través de un consejo directivo que legisla por ellos e instituye y promulga ordinaciones que sólo pueden ser derogadas por una mayoría cualificada ${ }^{273}$.

Las takkanôt tienen el valor de la libre adhesión y el del consentimiento de la comunidad; ningún dirigente podrá imponerla aunque se les reconozca iniciativa legislativa. El kahal es soberano y las takkanôt serán siempre takkanot hakahal u ordenanzas comunitarias, las cuales no puede vincular a los judíos de una localidad si una mayoría de éstos la considera intolerable ${ }^{274}$, ni aun admitiéndola si no proporciona beneficio - «tikun»--, quienes no están obligados a obedecerla ${ }^{275}$. Asimismo, una minoría organizada no electa carece de poder para legislar o aplicar la excomunión, si no cuenta con el beneplácito de la mayoría y los sabios de la ciudad, pese a tener como objetivo la sanción de un delito - legader uletikun - o el cumplimiento de una obligación religiosa - mitsvah- ${ }^{27}$. Los límites son, en suma, la injusticia flagrante o la transgresión halákhica ${ }^{27}$

Las nuevas necesidades surgidas tras los luctuosos episodios que hemos señalado más arriba, condujeron a los adelantados a proponer nuevas fórmulas de gobierno que se acomodaran al curso de los nuevos tiempos. De entre las diversas «cartas constitucionales» nos centraremos, por su carácter paradigmático y su pervivencia a lo largo de todo el siglo $\mathrm{xv}$, en las ordinaciones de la aljama de Zaragoza, promulgadas en $\mathbf{1 4 1 5}$ por Fernando I, tras dos intensos años de consultas y negociaciones ${ }^{278}$. Digamos como excursus que

271 Nedarim, 48 a.

272 Motis Dolader, Miguel Angel, «Contexto histórico-juridico de los judios del Reino de Aragón (siglos XI-XI): pluralidad normativa y preconfiguracion de las aljarnas), págs. 119-120.

273 En la época talmúdica, la mayoría de estas funciones estaban centralizadas en el beth din, mientras que en la Edad Media recae sobre la propia organización comunitaria. SHoHET, D. M., The Jewish Court in the Middle Ages. Studies in Jewish Jurisprudence, pág. 18.

274 Responsum de Rabi Isaac ben Sheshet Perfet, vol. II, núm. 279.

275 Responsion de Rabí Isaac ben Sheshet Perfet, vol. V, núm. 245

276 Responsum de Rabi Isaac ben Sheshet Perfet, vol. II, núm. 279.

277 Encontramos sucesivas reiteraciones a los límites de la autoridad comunitaria en personajes de la talla de rabi Yom Tov ben Abraham (Ritba) quien, después de asertar el principio de la ley de la mayoría af̃ade: «mientras parezca a la mayoría que una ordinación particular es beneficiosa para el colectivo y se aplique a todos por igual [Avodah Zarah, 36b]. En consonancia con todo ello, Isaac ben Sheshet y su joven colega R. Simon Duran, en su responsum a propósito de la prohibición de] juego, niegan a la comunidad el derecho de revocar una barrera protectora de la Torah. Ambas autoridades parten del principio de que la comunidad no tiene el derecho a la reversión mediante el voto mayoritario. [Responsum de Rabi Isaac ben Sheshet Perfet, núm. 178.]

278 La respuesta oficial aguardará al 22 de septiembre de 1412 . En ella se encomendaba a seis expertos judios, elegidos por Juan Desplá, doctor en leyes y tesorero real, con el concurso de Pardo

Hispania, LVI3, núm. 194 (1996) 885-944 
Fernando II, proseguirá su política de ratificar todos los privilegios anteriores, como sucede con la aljama de Gerona, que consolidará «tots privilegis, libertats, franqueses, inmunitats, usatges, promissions, gracies e concessions a ells per los senyors reys predecesor... atorgades ${ }^{279}$, mantiendo una política claramente continuista, respetuosa hacia las jurisdicciones procedentes del Medievo 280 .

Esta importantísima regulación -sobre cuyos articulados, confrontados con los de otras aljamas, nos regiremos en nuestra exposición doctrinal-, asienta definitivamente los órganos gubernativos de la aljama y sus atribuciones, en aras de la "conservación e proveyto d'aquellos aliama e singulares, attendientes que son thesoro del dito senyor e nuestro" ${ }^{28 r}$. Recordemos que en el año 1432 se promulgan las taqqanot de Valladolid que constituyen un documento de primer orden para el conocimiento del marco jurídico en el que se desenvuelven los judíos castellanos en un momento culmen de la historia del judaísmo peninsular ${ }^{282}$, máxime cuando les son reconocidos unos derechos y libertades paccionados que no habían tenido apoyo en los textos doctrinales precedentes, compartiendo algunas concordancias con las regulaciones aragonesas.

La puesta en marcha en este Reino de una estructura jerarquizada encabezada por un gran rabí, puede responder a la voluntad de dotar de una forma

de la Casta, merino de Zaragoza. Motis Dolader, Miguel Angel, «Las comunidades judías del Reino de Atagon en tiempos del papa Benedicto XII] (1394-1423): estructuras de poder y gobierno aljamials, op. cit.

279 BAER, Fritz, Die Juden im Christlichen Spanien. Erster Teil: Aragon und Navarra, vol. [, doc. 553 , pág. 893 .

Mientras tanto en Navarra las oligarquías se vieron obligadas a forzar serias medidas institucionales para preservar su agitada autoridad. En 1482, durante una breve estancia en este reino de Francisco Febo, promulgó un privilegio real por el que reconocía los poderes de tas autoridades existentes en Tudela y en las restantes aljamas de Navarra. GAMPEl, Benjamin R., The Last Jews on Iberian Soil. Navarrese Jewry 1479/1498, Los Angeles, 1989, pág. 52.

280 Pérez Martín, Antonio, Fori Aragonum vom Codex von Huesca (1247) bis zur Reform Philipps II (1547), Vaduz, Topos Verlag, 1979, págs. 37, 651, 872, etc.

281 VendRell Gallostra, Francisca, «Al margen de la organización de la aljama judaica de Zaragoza», Sefarad, XXIV (1964), pág. 84.

282 De este texto existen numerosas versiones, la más acabada de las cuales se debe MORENO Koch, Yolanda, "The Taqqanot of Valladoli of 1432», The American Sephardi, 9 (1978), págs. 58143. Son útiles las glosas, las más de ellas de naturaleza legal, incorporadas por Tomás L. Ryan de Heredia y Herman P. Salomón.

Entre sus predecesores: KAYSERLING, M., «Das Castilianische Gemeinde-Statu (Taqqanah). Zugleich ein Beitrag zu - den Rechts, Rabbinats-, und Gemeinde Verhältnissen der Juden in Spanien», Jahrbuch fit die Geschichte der Juden un des Judentums, IV (1869), págs. 263-334; Ordenamiento formado por los procuradores de las aljamas hebreas pertenecientes al territorio de los Estados de Castilla en la Asamblea celebrada en Valladolid el año I432. Texto hebreo rabínico mexclado de aljamía castellana. Traducido, anotado e ilustrado con una introducción histórica por Francisco Fernández y González, Madrid, 1886; LOEB, Isidore, «Réglement des Juifs de Castille en 1432 comparé avec les réglements des Juifs en Sicile et d'autręs pays», Revue des Etudes Juives, X[I] (1886), págs. 171-216. 
estable a la pirámide de jurisdicciones judías y dirigir una parte de las multas y caloñas percibidas por el magistrado supremo, juez en última instancia, hacia el tesoro público ${ }^{283}$. Pero a la vez es el resultado de una política que anhela institucionalizar, de forma cómoda, las comunicaciones entre el poder real y.las comunidades, capaz de administrar y transmitir las directrices axiales de la realeza, entre las que se encuentra hacer frente con rapidez a un repertorio de exacciones o sofocar un déficit presupuestario coyuntural ${ }^{284}$.

El poder en este siglo tiende a ser globalizador frente a la atomización inevitable del Alto Medievo, tanto bajo la forma de espacios económicos como en la esfera social -donde existe una jerarquía interna rígida, basada en vínculos corporativo-profesionales, de obediencia, fidelidad, familia o patronato- como en el ámbito administrativo-institucional. La coexistencia de todas estas células, requiere el concurso de instancias arbitrales cuya superioridad es reconocida como eminente. La soberanfa -imperium- se enmarca dentro de un sistema de reparto social de los poderes políticos iurisdictio- ${ }^{285}$.

La estatalización implica la desaparición del sistema de reparto social del poder político. Se refuerzan y acrecientan las facultades de los poderes centrales mientras decaen las instancias superiores e inferiores, la centralización determina el declive de las autonomías territoriales y administrativas. La monarquía católica tenderá al centralismo y al autoritarismo, lo que generará una mayor intromisión en las aljamas, de modo paralelo a como sucedía con los regímenes municípales cristianos, a través de la intervención en el proceso de conscripción.

Todos los cargos electos, configurados a lo largo de los capítulos desglosados, son de obligado cumplimiento y, por tanto irrenunciables ${ }^{286}$, recayendo sobre los que intenten eludir sus responsabilidad el embargo de todos sus bienes ${ }^{287}$. Se impone, amén de todo ello, «jurar segunt la forma acostumbrada de usar de su officio bien e lealment, a proveyto, segunt sus conciencias, de la dita Aliama, toda parcialidat, odio, favor, amor e proprio

283 NEUMAN, Abraham, The jews in Spain. Their social, political and cultural life during the Middle Ages, Philadelphia, The Jewish Publication Society of America, 1942, vol. I, pág. 145.

284 En estas latitudes del calendario en Aragón no hay una infraestructura similar a la existente en Castilla, sincronizada por Abraham Benveniste. A lo sumo, mantiene cierta similitud - un tanto lejana - con el apparatum las diputaciones catalanas, cuyos delegados se reunían con cierta periodicidad. La última reunión de la que tenemos constancia fehaciente, convocada en el mes de mayo de 1490 , con previa autorización de la Corona, propone dos puntos básicos de debate: los intereses fiscales y servicios del Patrimonio, y los concernientes a su organización interna iuxta morem. KRIEGEL, Maurice, Les juifs à la fin du Moyen Age dans la Europe Mediterraneénne, pág. 112.

285 HeSPANHA, Antonio, "Para una teoría de historia institucional do Antigo Regime», en Poder e Instituiçoes na Europa do Antigo Regime, Lisboa, 1984, págs. 26-27 y 35.

286 Motrs DolaDER, Miguel Angel, «Procesos de ejecución de deudas sustanciados ante los justicias locales en Aragón (siglo xv)», en Homenaje a fray José López Ortiz Anuario Jurídico y Económico Escurialense, vol. XXVI, Madrid, 1993, págs. 315-69.

287 VENDRELl GALLOSTRA, Francisca, «Al margen de la organización de la aljama judaica de Zaragozan, §55.

Hispania, LVJ/3, núm. 194 (1996) 885-944 
proveyto removidos ${ }^{288}$. No se permitirá la reelección para el desempeño de un cargo oficial - adelantados, clavarios, jueces, almosnero, juez de sisas o de apelación - sino una vez transcurridos dos años ${ }^{289}$.

\subsubsection{El Consejo}

La emanación directa de la aljama es el Consejo, situado a la cabeza del cuerpo sociopolítico en las ciudades de mayor entidad de la Corona como Barcelona 290, Valencia 291, Zaragoza ${ }^{292}$, Mallorca ${ }^{293}$, Huesca ${ }^{294}$, Perpiñán ${ }^{295}$, Alcolea ${ }^{296}$, Borja ${ }^{297}$, Játiva ${ }^{298}$, Murviedro ${ }^{299}$, etc. Desde su creación tiende a ser un órgano proporcional y representativo, a semejanza de la articulación social que lo sustenta y conscribe, incluyendo representantes de los tres «estados», bajo el principio de la elegibilidad ${ }^{300}$.

Esta instancia es revestida de la mayor autoridad comunitaria 301 , en cuanto que establecido o elegido por el cuerpo electoral de la aljama, lo que implica la ley de la mayoría ${ }^{302}$. A comienzos del siglo xv se establece en Zaragoza un Consejo compuesto por doce integrantes, cuatro por cada una de las manos, de donde procederán los cargos de adelantados y clavarios ${ }^{303}$. En las

\footnotetext{
$2 \times 8$ VeNDReLl Gallostra, Francisca, «Al margen de la organización de la aljama judaica de Zaragozas, \$ 54

2\%9 VENDRELl Gallostra, Francisca, «Al margen de la organización de la aljama judaica de Zaragozan, $\$ 26$.

290 Responsum de Rabi lsaac ben Sheshet Perfet. 214 y 228.

291 Responsum de Rabi lsaac ben Sheshet Perfet, 371 y 497.

292 Responsum de Rabí Isaac ben Sheshet Perfet, 388 y BAER, Fritz, Die Juden in Christlichen Spanien. Erster Teil: Aragon und Navarra, vol. I, pág. 131.

293 BAER, Fritz, Die Juden im Christlichen Spanien. Erster Teil: Aragon und Navarra, vol. I, pág. 473.

${ }_{294}$ Responsum de Rabí lsaac ben Sheshet Perfet, 195. BAER, Fritz, Die Juden in Christlichen Spanien. Erster Teil: Aragon und Navarra, vol. J, 256.

293 BAER, Fritz, Die Juden im Christlichen Spanien. Erster Teil: Aragon und Navarra, vol. I, págs. 487 y ss.

296 Responsum de Rabí Isaac ben Sheshet Perfet, 475-76.

297 Responsum de Rabi lsaac ben Sheshet Perfet, 249.

298 Responsum de Rabi Isaac ben Sheshet Perfel, 262.

299 BAER, Fritz, Die Juden im Christlichen Spanien. Erster Teil: Aragon und Navarra, vol. I, pág. 532

${ }^{300}$ BAER, Fritz, Die Juden im Christlichen Spanien. Erster Teil: Aragon und Navarra, vol. I, 511 y ss núm. 14; 580 y ss. núm. 2

301 Responsa de Rabi Salomón ben Adret (Sheelot u-Teshuvot), vol. V, núm. 125 y 245.

302 Responsa de Rabí Salomón ben Adret (Sheelot u-Teshuvot), vol. 1, núm. 617; vol. HI, núm. 394,416 y 434; vol. IV, núm. 312; vol. V, núm. 125 y 245.

${ }_{303}$ La crisis de algumas aljamas se tradujo en enormes dificultades para contar con gentes capacitadas para el desempeño de los cargos públicos. En el año 1392, el baile hubo de censar a los judios de Murviedro susceptibles de ocupar los puestos rectores, ordenando que anualmente se eligieran dieciséis personas para este cometido: dos adelantados, un adjunto, un clavario y doce consejeros. Hinojosa Montalvo, José, «Los judios del reino de Valencia durante el siglo xv», pág. 179.
} 
ordinaciones decretadas por Juan II en 1436 para reorganizar la aljama de Calatayud, se resuelve que el Consejo habrá de presentar idéntica configuración ${ }^{304}$. La aljama turiasonense, según una normativa sobre el «regimiento de los officiales" de 1420, estipula que el collegium se componga de nueve consejeros, tres de cada una de las manos respectivas ${ }^{305}$. En Huesca, desde 1374, se trazará un claro equilibrio, al integrar a cuatro miembros de cada estrato social ${ }^{306}$. Los qahales menores como Borja no precisan sino tres componentes ${ }^{307}$. Una epístola deferida el año 1424, por el baile general a los adelantados y clavarios de la aljama de Murviedro, les autoriza a la elección anual de cinco consejeros, con el fin de democratizar sus estructuras, controladas por los adelantados y el clavario, lo que generaba abusos en el campo impositivo y la multiplicación de las tensiones internas ${ }^{308}$.

Prosiguiendo con la comunidad de Zaragoza, sus atribuciones legislativas -promulgación de cualesquier "ordinacion, statuto o tachana"-, deberán contar con la connivencia y apoyo de diez personas de prestigio y honorabilidad intachables procedentes del cuerpo electoral de la aljama. El quorum mínimo para su otorgamiento precisará de nueve personas del Consejo o bien una mayoría natural de la suma de las personas egregias designadas y el Consejo ${ }^{309}$.

El papel básico asignado a este organismo -integrado por cuatro adelantados, un clavario y siete consejeros- es la representación legal de la aljama, pudiendo ejercer sus atribuciones con el voto favorable de nueve de ellos, es decir, las tres cuartas partes, debiendo encontrarse entre ellos los tres adelantados que legitiman la representación de las diversas «clases sociales" ${ }^{310}$. En las resoluciones que se adopten por parte de los componentes del Consejo al menos nueve de ellos, contando siempre con el concurso de los adelantados- y seis de las diez personas que, a modo de notables, serán escogidos para cada negocio de relevancia, tendrán la misma fuerza vinculante — siendo

\footnotetext{
304 Resultan elegidos por la mano mayor: Jehuda Aviayu, Calema Çadot, Mosse Çarfati, Zecri Lapapa; por ta mano media: Aron de Calo, Brahem Alpastan, Jaco Arueti y Jehuda Maymon, mientras que por la menor Açach Pazagon, Eliezer Calaveri, Samuel Alazar y Jehuda Abez. A.H.P.Z., Protocolo de Domingo de Hecho, 1436, guardas en pergamino.

${ }_{305}$ Como los restantes cargos el día de San Miguel de septiembre da comienzo con mandato que se extenderá por espacio de un año, eligiendo por cooptación a sus sucesores ocho días antes de la citada festividad. A.C.A., Real Cancilleria, Reg. 3.116, fol. 72. Pub. Serrano y Sanz, Manuel, Orígenes de la domincación española en América, doc. XXI, págs. CCCCLIX-CCCCLXI

${ }_{306}$ BAER, Fritz, Die Juden im Christlichen Spanien. Erster Teil: Aragon und Navarra, vol. I, págs. 525 y ss. núm. 14 y pág. 256 \& Motis Dolader, Miguel Angel, «Régimen fiscal de las comutidades judias de Aragón en la Baja Edad Media: la aljama de Huesca en el siglo xJVm, op. cit.

307 Motis Dolader, Miguel Angel, Los Judios de Borja en el siglo xv, Borja, 1987, pág. 49.

308 Hinojosa Montalvo, José, "Los judíos del reino de Valencia durante el siglo xv», Historia Medieval. Anales de la Universidad de Alicante, 3 (1984), pág. 153

309 VENDREll Gallostra, Francisca, «A1 margen de la organización de la aljama judaica de Zaragozan, $\$ 3$.

310 VENDRell Gallostra, Francisca, «Al margen de la organización de la ajjama judaica de Zaragozan, $\$ 4$.
}

Hispania, LVV3, núm. 194 (1996) 885-944 
de obligado cumplimiento- que si la hubiera adoptado la aljama en sesión plenaria. Carecen de esta legitimación los acuerdos que no cuenten con este preceptivo acuerdo de voluntades ${ }^{311}$.

Las atribuciones de soberanía, en consecuencia, son homólogas a la de la aljama - con la excepción de que no podrían realizar desembolsos superiores a diez florines en unidad de acto o cien florines anuales ${ }^{312}$-, entendiéndose que, realizada la votación, con el mínimo legal exigido, se casaría como si se tratare de una resolución adoptada por unanimidad. Si así lo requieren los tres adelantados o cualesquiera tres otros integrantes del Consejo, tienen la facultad de convocar a cinco o más personas, para que ejerzan la función de consejeros, siendo irrenunciable el cumplimiento de esta solicitud, bajo multa de veinte sueldos ${ }^{313}$.

En el supuesto de que el Consejo, haciendo uso de sus atribuciones soberanas, juntamente con los diez notables no colegiados en este órgano, entendieran necesario, en beneficio de la res publica, promulgar una "tachana o ordinacio», entrará en vigor siempre y cuando exista la oposición de uno sólo de los adelantados de cualquiera de las manos; a efectos del cómputo de votos se entenderá como persona singular, sin que pueda ejercer el derecho a veto. Esta regulación no se aplicará cuando los que no apoyan un acto de gobierno determinado representen los dos tercios del adelantazgo ${ }^{314}$.

Habida cuenta de la importancia del cargo, se demanda de sus dignidades sabiduría, inteligencia, prudencia, conocimiento y versamiento en asuntos comunitarios, temperancia, y la aceptación de la mayoría de sus conciudadanos ${ }^{315}$. En el seno del Consejo no pueden ejercer con simultaneidad el cargo dos componentes del mismo linaje, ni dos que, según la ley hebraica ${ }^{316}$, estuvieran privados de legitimidad para testificar recíprocarnente ${ }^{317}$.

Los responsables del "fecho de la aliama», antes de tomar posesión, habrán de jurar sus cargos, comprometiéndose a usarlo con lealtad y a guardar el secreto de sus deliberaciones ${ }^{318}$. El desempeño del cargo tiene una

3 II Vendrell Gallostra, Francisca, «Al margen de la organización de la aljama judaica de Zaragoza", $\S 5$.

312 VendRell Gallostra, Francisca, «Al margen de la organización de la aljama judaica de Zaragoza», § 6

313 Vendrell Gallostra, Francisca, «Al margen de la organización de la aljama judaica de Zaragozam, $\$ 7$

314 VENDRell Gallostra, Francisca, «Al margen de la organización de la aljama judaica de Zaragoza», $\$ 8$.

315 MOTIS DOLADER, Miguel Angel, «Sistema judicial de las comunidades judías de Aragón en el reinado de Fernando IIm, en Fernando II de Aragón. El Rey Católico, Zaragoza, Institución Fernando el Católico, 1996, págs. 321-322.

316 Maccoth, 6b-7a; Mishnah Sanhedrin, 26a; Sanhedrin, 27b; Yebamot, 25a-b, entre otros.

317 VENDREll Gallostra, Francisca, «Al margen de la organización de la aljama judaica de Zaragoza», $\$ 9$.

318 Vendrell Gallostra, Francisca, «Al margen de la organización de la aljama judaica de Zaragoza», § 10. 
duración anual, siendo objeto de renovación cada mes de agosto ${ }^{319}$, en que serán designados los doce componentes del Consejo, de los cuales se detraerán cuatro adelantados y un clavario, como hemos expresado más arriba, cuya elección será efectuada por el comisario delegado y una triarquía ajena al referido Consejo, «las quales tres personas juren en poder del Comissario esleyr la mayor suficiencia de cada huna de las manos en el numero e officios que devent segunt el tenor de las presientes ordinaciones» ${ }^{320}$. No se tolerará que los Consejeros, en nombre de la aljama, se endeuden en ninguna medida, por los excesos del pasado y la difícil situación financiera presente ${ }^{321}$.

En caso de imposibilidad de prestar la debida atención a sus obligaciones por indisposición, enfermedad, accidente o ausencia de la ciudad, los cargos electos podrán elegir los respectivos lugartenientes de su propio linaje, con conocimiento de sus colegas, siempre y cuando no sea ya miembro de pleno derecho del Consejo. La contravención se multará, en cada comisión, con la reprensión de quinientos sueldos de multa. Los mismos supuestos se prescriben para los Consejeros donde, en caso de incumplimiento de la regulación indicada, serían objeto de una multa de trescientos sueldos. Si pese a estas reconvenciones el titular no consiente en nombrar un legado, se procederá a su provisión por acuerdo de los consejeros de la mano correspondiente. Por último, se contempla —dado el nuevo signo de los tiempos- la posibilidad de mudanza en la fe, causa eficaz de cese en sus atribuciones, en cuyo caso, y con el concurso del comisario, se procederá a cubrir la vacante en un plazo de quince días ${ }^{322}$. La asistencia a los plenos es obligatoria, estando penada su incomparecencia, cada vez que ésta se produjese, con una multa de cinco sueldos en favor de las arcas reales ${ }^{323}$.

\subsubsection{Los adelantados}

Al frente de la comunidad política se sitúan cuatro adelantados, a los que se encomienda la gestión de los asuntos públicos de la aljama «faziendo e exerciendo todo lo que a su officio perteneçca fazer e exercir». En términos generales, entre sus poderes delegados esenciales una de las funciones más importantes de los mukdamim fue poner en ejecución las ordinaciones ${ }^{324}$

\footnotetext{
319 Vendrell Gallostra, Francisca, «AI margen de la organización de la aljama judaica de Zaragoza», $\$ 65$

320 VENDREll Gallostra, Francisca, «Al margen de la organización de la aljama judaica de Zaragoza», § 11 .

321 VENDREll Gallostra, Francisca, «Al margen de la organización de la aljama judaica de Zaragoza», $\$ 18$.

322 Vendrell GallostRa, Francisca, "Al margen de la organización de la aljama judaica de Zaragoza», $\S 12$.

${ }^{323}$ VendRell Gallostra, Francisca, «Al margen de la organización de la aljama judaica de Zaragoza», § 13.

324 Responsum de Rabi Isaac ben Sheshet Perfet, 476
}

Hispania, LVI/3, núm. 194 (1996) 885-944 
promulgadas por la comunidad o el Consejo ${ }^{325}$, actuando como agentes ejecutivos e intérpretes de la norma fundamental ${ }^{326}$, como sucede desde el siglo XIV,

En las ordinaciones turiasonenses antes citadas se determina: «jutgar e determinar todos e qualesquiere pleytos et cuestiones que adelant dellos vendran... [las causas sean entendidas e determinadas segunt la ley judayca]" y "costrenyr a los singulares sobre las cosas tocantes a la ley judaica, o a feyto d'anima - esta vigilancia sobre la conducta moral se aprecia en comunidades tan dispares como Zaragoza, Calatayud, Jaca, Teruel, Valencia, Játiva, Alcira y Murviedro ${ }^{327}$-, o ad almosna, o spitales, o semblantes cosas ${ }^{328}$.

Su permanencia en el cargo es anual, habiendo de ser elegidos el último día de agosto, con participación equitativa de los tres brazos. Esto es, en el transcurso de un trienio, y dado que suman un total de cuatro en cada ejercicio, en un mandato cada una de las clases sociales tendría en el gobierno dos representantes, mientras que las restantes contarían con uno, lo que suponía que los intereses de un estamento preponderarían a priori, aunque sin tener la mayoría necesaria ${ }^{329}$, como ya sucediera en la novación introducida por la reina doña Violante en 1399 330.

Los estatutos turiasonenses incluyen las condiciones que han de cumplir los aspirantes: respecto a la consanguinidad: «que no sean ensemble de los parentescos que veda la ley judayca, el qual es daquia el segundo grado, assi como fillos de dos hermanos e semblantes"; conocedores de la ley hebrea: "los que son mas expertos en la ley judayca e mas scientes de tota la aliama»;

325 Responsum de Rabi lsaac ben Sheshet Perfet, 497 y Responsa de Rabi Salomón ben Adret (Sheelot u-Teshuvot), vol. III, 409 y vol. V, 221.

326 HeRSHMAN, Abraham Moses, Rabbi Isaac ben Sheshet Perfet and his times, Jewish Theological Seminary of America, New York, 1943, pág. 109

327 BAER, Fritz (Yitzhak), Historia de los judios en la Corona de Aragón (siglos XIII y XIV), Zaragoza, 1985, pág. 118 , nota 27

328 A.C.A., Real Cancillería, Reg. 3 116, fols. 72-74v. Pub. Serrano y Sanz, Manuel, Orígenes de la dominación española en América, págs. CCCCLIX-CCCCLXI.

329 Vendrell Gallostra, Francisca, «Al margen de la organización de la aljama judaica de Zaragoza", $\$ 1$.

330 Atendiendo a las vindicaciones de la corriente democrática, introdujo enmiendas a las takkanôt aprobadas tres antos antes epor la variacion de los tiempos e la malicia de las gentes, las ordinaciones que en un tiempo son e apparexen buenas, en otro son contrarias a lur fin, et huey paresca a muytos la dita ordinacion e regimiento en algunas cosas seyer defallient e en otras seher mitigador. Por esto nos, attendientes al proveyto de la dita aljama e al buen stamiento de aquella, havido maduro e solemne consello, ordenamos e queremos que ad aquell sean feitas las moderaciones $\mathrm{e}$ anedimientos de iuso scriptosm. Entre sus trece considerandos del memorandum se estatuye que la elección de los adelantados seria estamental, mientras que la del clavario se efectuaria por todos los electores, estableciendo un distrito único, frente a lo establecido por el Rabíno que disponia la elección de cuatro personas en dicho collegium, de los cuales se escogeria el clavario o «recebidor de las monedas de la dita aljama». Se establece un sistema rotatorio por el cual las «quatro personas abonadas", que permanecerán en el poder por espacio de un año. BAER, Fritz, Die Juden in chris. thichen Spanien. L. Aragonien und Navarra, vol. I, doc. 467 
integridad moral: «que sean de buena vida e honesta, e que no sean ignorantes, ni jugadores" ${ }^{331}$.

Contamos, en Daroca, con un acta notarial de «eleccion de adelantados», de mediados de la centuria, poco después de la reconstrucción de sus órganos comunitarios ${ }^{332}$. La reunión no es convocada por los adelantados salientes sino que es promovida por el lugarteniente de baile, en ausencia de su titular, como supervisor de la limpieza en la elección. El cónclave se celebra en la sinagoga nueva. Como paso previo se pone de relieve la existencia del consenso comunitario «e para seyer aliama concordes». Cumplidas las formalidades de rigor -convocatoria, comparecencia del cuerpo electoral- "slieron en adelantados de aquella paral anyo present a Sumiel Adich e Jaquo Abennicaf, a los quales daron todo aquel poder que a adelantados es atribuydo e devent haver" ${ }^{333}$.

Los adelantados, tras el arrendamiento de las sisas, cuentan con ocho días para negociar, de común acuerdo con el clavario, los censales, pensiones y salarios. Para escoger las personas que establezcan las prorratas será necesario el concurso de los consejeros y diez personas ajenas a estos órganos de poder. Las resoluciones habrán de contar con los votos de nueve consejeros y seis personas ajenas a ese collegium para considerarse vinculantes; de otro modo se procederá a su devolución ${ }^{334}$.

Dentro del período señalado para el supuesto anterior, tienen la potestad de nombrar los gestores de las limosnerías, con el acuerdo del Consejo, recayendo sobre una persona proba no intergrada en cualquiera de los resortes de poder. La misma facultad les asiste en la designación del albedí, cuyo cargo no admite la delegación en un lugarteniente, y por cuya regalía la aljama tributa ochenta sueldos al alcaide de la jurisdicción ${ }^{335}$.

\subsubsection{La judicatura ${ }^{336}$}

El principio de la personalidad de las leyes había jugado un papel esencial, puesto que proclama que cada uno debía ser juzgado según los principios del cuerpo doctrinal al que se adhiriera. Que un judío fuera rechazado según la ley judía no podía extrañar a una sociedad que admitía y proclamaba la exis-

331 A.C.A., Real Cancillería, Reg. 3116 , fols. 72-74v. Pub. Serrano y Sanz, Manuel, Orígenes de la dominación española en América, pág. CCCCLIX-CCCCLXI.

332 Motis Dolader, Miguel Angel, The Jews of Daroca and its Community in the Middle Ages, Colec. Hispania Judaica, Magnes Press, Jerusalem (en prensa).

333 A.H.P.Z., Protocolo de Joan Ram, Daroca, 1459, fols. 71-71v.

334 VendRell Gallostra, Francisca, «Al margen de la organización de la aljama judaica de Zaragozam, $\$ 14$.

335 VENDRELl Gallostra, Francisca, «Al margen de la organización de la aljama judaica de Zaragozan, $\$ 29,30$.

336 Motis Dolader, Miguel Angel, «Sisterna judicial de las comunidades judías de Aragón en el reinado de Fernando IIs op. cit.

Hispania, LVV/3, ním. 194 (1996) 885-944 
tencia de distintos órdenes y que justificaba la aparición de comunidades humanas diferentes. Los judíos debían escapar del Derecho canónico y someterse al rabínico ${ }^{337}$.

La regulación zaragozana de 1376 mostrará una notoria pervivencia durante el siglo xv. En la primera década de esta centuria, Martín el Humano, ratificaba que las causas civiles y criminales — con las objeciones que en su momento aducíamos- deberían ser conocidas según los fueros, usos y costumbres del Reino ${ }^{338}$; los pleitos civiles internos quedaban al arbitrio de los magistrados judíos, comprometiéndose a no medrar en busca de beneficios económicos mediante intervenciones puntuales en el iter procesal. No transcurriría mucho tiempo hasta que los jueces de Zaragoza fueran investidos de autoridad para aplicar sanciones patrimoniales o aflictivas, y se reconociera que uno sólo de ellos pudiese seguir el proceso, tanto en lo civil como en lo penal, hasta que se produjera la sentencia definitiva o hasta la interlocutoria ${ }^{339}$.

La autonomía judicial sufre un truncamiento pasajero el 23 de junio de $1415^{340}$, bajo la influencia de la Bula de Benedicto XIII, en virtud de la cual Fernando I dejó sin efecto el citado reglamento de 1376, contenido, por cierto, en las takkanôt a las que nos venimos refiriendo ${ }^{341}$. Esta vacatio legis no duró más de un cuatrienio, al ser restablecido por Alfonso el Magnánimo, en ratificaciones sucesivas producidas en 1447,1448 y $1457^{342}$. Su sucesor -Juan

337 Schwarzfuchs, Simon, Kahal. La communauté juive de l'Europe Médiévale, Paris, Majsonneuve et Larose, 1986, pág. 84.

Lo que no significa que los tribunales eclestásticos carecieran de jurisdicción sobre ellos en algunos supuestos concretos. FalCon PÉREZ, Isabel y Motis Dolader, Miguel Angel, «Documentación judicial del Arzobispado de Zaragoza en el Antiguo Régimen», en Reunión Científica Internacional. Valoración del Estado de las Fuentes Históricas, Jurídicas y Literarias hispanas ante el siglo XXl, Barcelona, Universitat, 1996 (en prensa).

338 El corpus jurisprudencial u Observancias, a mediados del sig!o xv, determina que sí un judio o un infiel es incriminado por un cristiano de un delito cometido contra otro cristiano o contra le ley de los cristianos, no se debe respetar su zuna o costumbre, no considerándose ad́misibles como testigos de cargo sino los cristianos. Sentenciando que se atendrá a fuero en lo que perjudique las pretensiones del infiel pero no en aquéllo que le beneficie. "In iis quae faciunt contra infidelem, servabitur Forus; in hiis vero quae pro ipso faciunt, minimem. SAVALl DRONDA, Pascual y PENÉN Y Debesa, Santiago, Fueros, Observancias y Actos de Corte del Reino de Aragón, Zaragoza, 1991, vol. II, pág. 56b.

339 BLASCO, María Asunción, «La autonomía judicial de los judios de Zaragoza: normativa de 1376», Sefarad, 52 (1992), págs. 323-336.

340 Serrano y SANZ, Manuel, Orígenes de la dominación española en América, págs. CCCCLVII-CCCCLIX.

341 VENDRELL GaLLOSTRA, Francisca, «En tomo a la confirmación real de la pragmática de Benedicto XII», Sefarad, XX (1960), págs. 319-51; «La aljama judaica de Teruel y la proclamación de Fernando de Antequera», Homenaje a Johanes Vincke, I, Madrid, 1962, págs. 279-284; «Al margen de la organización de la aljama judía zaragozanas, Sefarad, XXIV (1964), pág. 95 núm.. XXVIII.

${ }_{342}$ A.C.A., Real Cancillería, Reg. 2.616 , fols, 185,268 v y 284-85 \& SERrano y Sanz, Manuel, Orígenes de la dominación española en América, pág. CCCCLXXIX. 
II- - tras ratificar la imprescriptibilidad jurídica de lo estatuido por Pedro IV, ordenaba que se hiciera un traslado auténtico del mismo ${ }^{343}$.

El tribunal de los berorim constará de cinco miembros «que sepan leyr ebrayco e roborar", uno de los cuales a propuesta de la familia de los Alazar y los cuatro restantes de condición, debiendo contar con la anuencia y el beneplácito de los adelantados, proveyéndose este empleo en los ocho días posteriores a la constitución del gobierno comunitario. Si éstos últimos no llegaran a un acuerdo en el plazo prescrito, la elección correspondería a los consejeros. El mismo procedimiento se adopta en la designación de los jueces de apelación, en evitación de toda indefensión del justiciable ${ }^{344}$.

Es imperativo que «segunt contiene el privilegio de la judicatura que la dita aliama tiene del senyor rey", que celebren audiencia cuando menos dos o tres días por semana, bajo multa de quinientos sueldos que engrosarán las arcas del Patrimonio Real y el arón de la comunidad, por partes iguales ${ }^{345}$. En primera instancia no se podrá apelar sino a otro juez judío, con la excepcion de la Corte real, que se posee, en todo caso, la prelatura jurisdiccional ${ }^{345}$, que reserva al soberano el derecho de apelación y gracia ${ }^{347}$, porque su poder es independiente de cualquier potestad externa ${ }^{348}$.

\subsubsection{Otros funcionarios de la Administración}

Además de los órganos colegiados analizados con anterioridad, y que articulan los principales resortes de poder de la aljama, existen cargos u oficios públicos de designación real o interna. Nos detendremos únicamente en los más relevantes.

La extracción del clavario no se adscribe a su pertenencia a una mano determinada, sino que viene determinada por sus cualidades de competencia

343 A.C.A., Real Cancillería, Reg. 3.375, fol. 53.

344 Schwarzfuchs, Simon, Kahal. La communauté juive de l'Europe Médiévale, pág. 94.

345 El tribunal de Zaragoza, por su parte, siguiendo esta misma línea, celebra vistas los miércoles y los domingos. LACAVE, José Luis, «Pleito judio por una herencia en aragonés y caracteres hebreos. Notas acerca del procedimiento judicial en los tribunales judios aragoneses», Sefarad, XXX (1970), pág. 331.

346 VENDRELl GALlostRA, Francisca, «Al margen de la organización de la aljama judaica de Zaragoza», § 28.

Cfr. Molino, Miguel del, Repertorium fororum et observantiarum regni Aragonum, una pluribus cum determinationibus Consilit Justitiae Aragonum, practicis atque cautelis eiusdem fideliter annexis, Cesaraugusta, 1585, sub voce «Iurisdictio», fols. CXCVIIv-CC.

347 SÁNCHEZ AGESTA, Luis, El concepto de Estado en el pensamiento español del siglo XVI, Madrid, 1959, págs. 72-168 \& GoNZÁLEz ALONSO, Benjamin, "Jerónimo Castillo de Bobadilla y la "Política para corregidores y señores de vasallos", 1597", en Sobre el Estado y la Administración de Castilla en el Antiguo Régimen, Madrid, 1981, págs. 102-103.

348 Dios, Salustiano de, «El Estado Moderno. ¿un cadáver historiográfiço?», en Realidad e Imágenes de Poder. España a fines de la Edad Media, Valladolid, 1988, pág. 404.

Hispania, LVU/3, nủm. 194 (1996) 885-944 
y honestidad, habida cuenta de que desempeña el cargo de «recebidor e distribuydor de las monedas de la dita aliama». La provisión del cargo se realiza anualmente coincidiendo con la proclamación de los adelantados, en previsión de que no se produzca un vacío de poder ${ }^{349}$.

El clavario, ocupado de la percepción proviniente de "sisas, tallas, prestamos, malieutas», etc., es remunerado anualmente con setenta florines de oro, habiendo de entregar una fianza de 20.000 sueldos, para atender presuntas responsabilidades civiles subsidiarias, cantidad que muy pocos podían subvenir, siendo causa de inadmisibilidad en el cargo la no cumplimentación de este requisito. Tienen, además, poder de constreñir y ejecutar a los morosos sin recurrir al juez y obligar a los arrendadores al pago pactado. En un plazo de cuatro meses, tras haber prescrito su mandato --bajo pena de cincuenta florines y anatema - o en el momento en que sea requerido por los adelantados, deberá rendir cuentas de su gestión administrativa, con las apocas y albaranes debidamente autenticados, «de manera que si ha dineros en su poder que puedan socorrer a las necesidades de la dita aliama” ${ }^{350}$.

El clavario-que puede ser depuesto por incompetencia, mala gestión o desviación de poder ${ }^{351}$ - habrá de efectuar los libramientos que mediante "albaran publico de notario o roborado de mano" requieran los adelantados - los tres o tan sólo dos- por un importe máximo de diez sueldos en un acto unitario o de trescientos sueldos anuales ${ }^{352}$. Los integrantes del Consejo tiene una mayor capacidad dispositiva: diez florines unitarios y cien globalmente. Este techo sólo podrá alcanzarse graciosamente, con el concurso de una decarquía formada por personas ajenas a los órganos de gobierno ${ }^{353}$. El Consejo se compromete a entregar un cabreo normalizado al clavario con todas las cargas ordinarias y demás cartas de deudo y comandas que recaigan sobre la aljama ${ }^{354}$.

Los tres jutges de las sisas son elegidos por los adelantados, dentro o fuera del Consejo, uno por cada una de las manos, sin que puedan mantener grado de parentesco ninguno con los arrendadores de impuestos, ocho días después de haberse proclamado los cargos directivos de la aljama ${ }^{355}$. Los seis tasado-

349 Vendrell Galiostra, Francisca, «Al margen de la organización de la aljama judaica de Zaragoza», \$ 2 .

350 VENDRELL GaLlostra, Francisca, «A] margen de la organización de la aljama judaica de Zaragozas, $\$ 15,16,17,19,20,21$ y 22. Cfr. Motis DolADER, Miguel Angel, «Los notarios y la documentación jưfía a través de las Taqqanôt otorgadas por el infante Alfonso $\mathrm{V}$ a la aljama zaragozana en 1415\%, en El Patrimonio Documental y la Historia, Zaragoza, 1986, págs. 261-272.

351 Como en 1436, en que a instancia del monarca los adelantados de Murviedro cesan de Jacob Alagian. Hinojosa Montalvo, José, «Los judíos del reino de Valencia durante el siglo XV», pág. 153.

352 Esta atribución es universal. SECALL 1 GuELL, Gabriel, Les jueries medievals tarragonines (Aportació Històrica), Diputación de Tarragona, Estudis Vallencs, XIV, Valis, 1983, pág. 55.

353 VendRell Gallostra, Francisca, "Al margen de la organización de la aljama judaica de Zaragozas, \$\$23.

354 VENDRell Gallostra, Francisca, «Al margen de la organización de la aljama judaica de Zaragozam, $\$ 24$ y 25 .

355 VENDRELl Gallostra, Francisca, «Al margen de la organización de la ajjama judaica de Zaragoza), § 27. Otras disposiciones cornplementarias en $\$ 43-53,56-7$ y 61-63. 
res de las propiedades judías de la ciudad y su área son conscriptos por mayoría simple, en votación realizada por los consejeros, respetando una rigurosa paridad de las clases sociales y la estimación que realicen estará en vigor durante tres años ${ }^{356}$. Se entiende incompatible con el desempeño de cargo público el arrendamiento de impuestos 357 .

En efecto, las aljamas sustantivan su autonomía jurídica con la existencia de fedatarios propios que tomaban posesión en una asamblea plenaria donde habian de prestar juramento en presencia del baile ${ }^{358}$. No se someten a periodicidad en su elección ya que entran en consideración factores de profesionalidad.

Su sanción depende del señor jurisdiccional de las aljamas de señorío, como lo dernuestra un acto público producido en la sinagoga de Epila el año 1482, en el que comparece Salamón Leví, donde muestra a los adelantados y demás concurrentes un privilegio sobre la notaría, extendida cinco días antes, en que se ratifica que "nuevament [había sido] proveydo la autoridat de la notaria suspendiendo qualesquiere otros notarios» ${ }^{359}$. Esta provisión infería lesiones a rabí Acach Cedillo y a Mossé Haddax que —con oficiosidaddesempeñaban este cargo, si prestamos atención a su requerimiento en el sentido de "que salvo les romaniesse su drecho de notarios que tenian etc". La aljama acató las órdenes del señor ${ }^{360}$.

Prosiguiendo con la aljama zaragozana, la regulación prescribe la necesidad de establecer un emplazamiento seguro en el Castillo de la judería del archivo de la aljama, custodiado en una o dos cajas con sendas cerraduras donde se contengan *los privilegios, libertades e provisiones, e otras scripturas fazientes por la dita Aliaman. Como custodios de ese depósito el Consejo destacará a dos escribanos judíos o a dos hombres íntegros de la comunidad, conservando en su poder las llaves respectivas. Los legajos serán inventariados y una copia de la relación se entregará a los adelantados o los consejeros. El consejo procurará cubrir inmediatamente las vacantías ${ }^{361}$.

La importancia documental como prueba judicial se pone de relieve en el sentido de que uno de los cometidos que habrán de perfeccionar los adelantados en los ocho días subsiguientes a su proclamación consistiría en lanzar anatema contra todo vecino que, teniendo en su poder "privilegios, libertades

356 Estas y otras disposiciones subsidiarias de naturaleza fiscal se contienen en VeNDRELL. Gallostra, Francisca, «A] margen de la organización de la aljama judaica de Zaragoza», $\$ 31$ a 41

357 Vendrell Gallostra, Francisca, «Al margen de la organización de la aljama judaica de Zaragozan, \$ 42 .

358 Motis Dolader, Miguel Angel, «Judios y judeoconversos de la Raya Occidental del reino de Aragóns, en Borja y la Raya Occidental en Aragón. Ponencias, Zaragoza, Institución Fermando el Católico, 1993, pág. 97.

359 Este testificará, por ejemplo, la quetuba de Soli de Levi, fechada en Epila el 15 de Tamuz del an̄o 5241 (primeros de junio de 1471). A.H.P.Z., Protocolo de Antón de Aviego, 1483, fols. $11 \mathrm{v}-12$.

360 A.H.P.Z., Protocolo de Antón de Aviego, 1482, fols. $21 \mathrm{v}-22$.

361 Vendrell Gallostra, Francisca, «Al margen de la organización de la aljama judaica de Zaragoza», \$58.

Hispania, LVU/3, nim. 194 (1996) 885-944 
e provisiones, e otras qualesquiere escripturas fazientes por la dita Aliaman, no los reintegre a sus legítimos propietarios en un período que finaba tras quince días naturales ${ }^{362}$.

El notario, como cauce de autenticidad del tráfico negocial, no podría negarse nunca a realizar un documento cuando era requerido para ello «sive contra dominum, aut contra concilium loci unde est cotarius: aut contra quemcumque alium quotiescumque per aliquem fuerit requisitus» 363 . Para garantizar la fidelidad de la documentación notarial, se habilitaba un proceso especial y expeditivo que se iniciaba a instancia de parte, sin ninguna limitación para la parte actora, y que, por la mera acusación de falsedad documental, ocasionaba la prisión del notario o su citación ante la Corte del Justicia ${ }^{364}$.

El escribano del concejo recibirá un estipendio de doscientos sueldos "por seguard de sus treballos, e por quales quiere scripturas, assi publicas como privadas, que seran ordinarias e costumbradas fazer en el dito Consello» - su retribución está foralmente consignada entre los cristianos ${ }^{365}$, no pudiendo pertenecer al Consejo por la autonomía de voluntad que entrañaba el depósito de la fe pública ${ }^{366}$.

\subsection{Democratización del poder; el triunfo de la insaculación ${ }^{367}$}

El sistema de insaculación, que en Aragón sustituye al sufragio y la cooptación, es introducido paulatinamente por Alfonso V, dotando de carta de naturaleza el acceso paritario de los representantes de los estratos sociales y atenuando la perpetuación endogámica de los cuadros dirigentes ${ }^{368}$, lo que no

362 Vendrell Gallostra, Francisca, «Al margen de la organización de la aljama judaica de Zaragoza), § 59 .

363 Fuero De notariis, ut certus sit in quolibet loco numerus eorumdem. SAVALL. DRONDA, PaScual y PENÉN Y DEBESA, Santiago, Fueros, Observancias y Actos de Corte del Reino de Aragón, vol. I, pág. 188.

364 Fuero De crimine falsi. SAVAll Dronda, Pascual y PEnén y Debesa, Santiago, Fueros, Observancias y Actos de Corte del Reino de Aragón, vol. I, págs. 325-327.

365 Fuero De salariis notariorum. SAVALL DRonda, Pascual y PENÉN y DeBesA, Santiago, Fueros, Observancias y Actos de Corte del Reino de Aragón, vol. I, págs. 196-197.

366 Vendrell Gallostra, Francisca, «Al margen de la organización de la aljama judaica de Zaragoza", $\$ 64$.

367 Su aplicación universal se produce en la segunda mitad del siglo XV. Motrs DOLADER, Miguel Angel, «Lineas programáticas de la legislación sobre judios y judeoconversos en el reino de Aragón en la segunda mitad del siglo XVm, op. cit.

La práctica insaculatoria híbrida y la elección en dos grados es utilizada por cristianos y judios desde 1375 , y su duración es muy elástica. Guillere, Christian, «Juifs et Chréstiens a Gerone», Jornades d'Història dels Jueus a Catalunya, Girona, Ajuntament de Girona, 1987, pág. 52

368 Font Rius, José María, «Las instituciones de la Corona de Aragón en la primera mitad del siglo XV», en IV Congreso de Historia de la Corona de Aragón, Palma de Mallorca, 1955, Ponencias, pág. 13. 
redime de manera radical los abusos o vicios que quería erradicar ${ }^{369}$ y que el sistema anterior habia fomentado ${ }^{370}$. El sincretismo con la sociedad cristiana no deja de ser esclarecedor, pues este procedimiento es usado en la provisión anual de cargos electivos en la administración municipal, en la Diputación del Reino y en otros ámbitos de poder local ${ }^{371}$, en lo que algunos autores han advertido un tentáculo más del autoritarismo monárquico ${ }^{372}$, que muy bien podría aplicarse, en cierto sentido, a las aljamas mudéjares y judías.

El sistema electoral consistía en anotar los nombres de los aspirantes a los cargos directivos del kahal en cédulas de pergamino que eran recubiertas de cera, formando así unas bolitas rojas, de idéntica forma, peso y color, llamadas teruelos o redolinos, introducidas en sacos independientes. Estas eran extraídas por un impúber que no hubiera cumplido los diez años, en una ceremonia compleja rodeada de ciertas garantías de procedimiento. En Zaragoza -cuyo concejo estableció el regimen del saco en $1441^{373}$ - los teruelos se cus-

369 Un documento fechado en marzo de 1480 nos pone sobre la pista de parte de la estructura gubernativa de la aljama judía de Jaca. El tema es suscitado en presencia de Martino de Rayca, notario, por luce Carffati, quien, en nombre propio y como una de las seis personas elegidas y procuradas por la aljama «pora nombrar las personas abtas etc., al officio de la adelantaduria, almosneros et almutacaffes, judges de apelaciones e conselleros de la dita aliama delant el senyor rey ultima en el anyo mas cerca passado pora el tienpo esdevenidero", interpone una denuncia. Como procurador de su hermano Rabi Baruch Carffati, requería a rabj Açah Almosnin, judio, notario real, habitante en Jaca, con el fin de que le entregase una copia de la carta publica de dicha elección de las seis personas efectuada por la aljama y de todas las actuaciones que la rodearon y coadyuvaron. Igualmente reclama una carta pública formalizada donde se contuviera cierta prórroga en la nominación de los oficiales realizada por los cinco restantes miembros, con la protesta expresada de Juce Carffati y rabí Baruch, principal suyo. El notario juđio interpelado arguye que siendo actos aljamiales ignoraba si le podía expedir copia, por lo que deberia consultar si era permisible o no. De lo que no mostraba duda alguna era lo improcendente de esta petición en tal fecha como aquélla, víspera de Pascua: «Por otra parte que por quanto era viespra de su Pascua et obstant aquella a el fuesse prohibido de poder fazer tales actos ni executar testifficados et cautela que demandavan etc». El procedimiento electoral diseñado se clarifica a nuestros ojos. La aljama delega su soberanía en una sextarquia - dos representantes de cada mano- con lo que se emite un sufragio indirecto, A.H.P.H., Protocolo núm. 8.028, Jaca, 1480, fol. 25v.

370 A este respecto resulta esclarecedor el trabajo de LALIENA, Carlos e IRANZO, Teresa, «El grupo aristocrático de Huesca en la Baja Edad Media: bases sociales y poder político», en Les sociétés urbaines dans la France Méridionale et la Péninsule Ibérique au Moyen Age, Paris, C.N.R.S., 1991, págs. 183-202.

371 ANGOY GARCiA, José Luis, "Guía metodológica para el estudio de la insaculación de cargos concejiles a través de los libros de Actas", en III Jornadas de Metodología de la Investigación Científica sobre fuentes aragonesas, Zaragoza, Instituto de Ciencias de la Educación, 1988, págs. 327328.

372 ToRras I Ribe, J. M. ${ }^{a}$, «El procedimiento insaculatorio en los municipios de los reinos de la Corona de Aragón, entre la renovación institucional y el sometimiento a la monarquía (14271714)», Jerónimo Zurita y su época, Zaragoza, 1986, págs. 341-352.

373 FALCON PÉREZ, Isabel, Organización municipal de Zaragoza en el siglo XV, Zaragoza, 1978, págs. 23-26 \& «Origen y evolución del régimen municipal de Zaragoza», en X Congreso de Historia de la Corona de Aragón, Zaragoza, 1979, págs. 261-272.

Hispania, LVI/3, núm. 194 (1996) 885-944 
todiaban en un cofre con tres llaves -ampliables a seis-, que permanecían en poder de los adelantados y el clavario, en la cámara del aron de sinagoga mayor o de Becorolim ${ }^{374}$. La limpieza electoral era crucial, pues los electos debían avalar el principio de quidad y corresponsabilidad fiscal de todos los miembros de la aljama, que los intereses de una sola facción ponian en entredicho ${ }^{375}$

También la elección de cargos del gobierno gerundense se rige -en el último tercio de la centuria - por una regulación dada el 20 de septiembre de 1459, por la que se disponfa adjudicación insaculatoria. Con tal fin ordena que se dispongan dos bolsas en las que se introducirían los pequeños rollos de pergamino con los nombres de aquellas personas aptas e idóneas para ocupar los cargos. Las bolsas se guardarían dentro de una caja que dispondría para su cierre de tres cerraduras, quedando en poder de otros tantos dignatarios aljamiales. De este modo, sin la presencia al unísono de los tres custodios de las llaves, no se podría proceder a su apertura. El 15 de enero de cada año se debían reunir en la sinagoga los miembros que integraban el concejo de la aljama para proceder al acto de extracción para el ejercicio anual que entonces daba comienzo ${ }^{376}$.

En la elección de los cargos existe una especie de «democracia censitaria» pues - como acaece en Calatayud- eran elegibles para los cargos públicos de la aljama, como los adelantados y claveros, sólo quienes pagasen de talla o de pecha más dos florines anuales. Esta disposición fue novada por el rey

374 Serrano y Sanz, Manuel, Orígenes de la dominación española en América, págs. CCCCLIX-CCCCLXI.

375 De hecho, este problema, suscitado a propósito de la pecha de la aljama de Jaca, obliga el 14 de abril de 1491 a convocar una reunión presidida por Gento Avdali, adelantado del ejercicio anterior y recusado por la mano menor, y los consejeros de aquel año, Caçón Alcalá, rabí Jeudá Almosnin, Baruch Alnieta, Jeudá Carfaci, hijo de Baruch, Sento Papur, con asistencia de Sento Abengoyos, Alazar Alcalá, Simuel Abanbrón, Sento Abendavit, Jeudá Carfaci, hijo de Jucé, Jeudá Carfaci, hijo de Faranel, Juce Carfaci, hijo de Açach, Jacob Altexefi, Juce Carfaci, hijo de Salamón, Jeudá Papur, Baruch Carfaci, tejedor, Jucé Carfaci, menor, hijo de Salamon. En ella designan como procuradores a Juce Carfaci, hijo de Jeuda, adelantado del año pasado, con el fin de comparecer ante el rey de Aragón o su lugarteniente general, a propósito de un estatuto -azquama - promulgado por los adelantados y el consejo - que posee iniciativa legislativa conjunta- y suplicar que, atendiendo «que en el anyo mas cerqua passado los adelantados de la dicha aljama fueron sleydos por otros y ellos podrian sleyr otros iusta serie y tenor de hun privilegio real que la dicha aljama tiene», y como dichas elecciones causaban gran confusión en la aljama y defendiendo que «el bien y repato de aquella sea fazer insaculacion por suerte de redolinos». Esta legitimación de los eiectos va unida a la calamitosa situación financiera atravesada — wa dicha aljama tiene y esta cargada de muchos censos y peytas y tienen tantas cargas que sinse echar y compartir la peyta no tenga la dicha aljama reparo otro alguno pora pagar los dichos censos y cargos de la dicha aljama»-, pues solicita sea aprobada una nueva pecha. Sólo el reparto equitativo y prorrateado de la pecha y la sisa podian devolver la paz social. A.M.J., Documentos sueltos, caja 5, doc. 66.

376 Mirambell Belloc, Enrique, «Documentos para el ordenamiento jurídico y económico de! barrio judío de Gerona (siglo XV)», en La Ciudad Hispánica durante los siglos XIII al XVI, t. II, Madrid, 1985, págs. 1465-68. 
D. Martín en una real cédula dada el año $13988^{377}$. Con los Reyes Católicos se mantiene esta tónica, ya que "para ser admitido y conlocado en las bolsas de los officios de adelantado y clavarios de la mano mediana ${ }^{378}$ de la dicha aljama» debían pechar a la aljama «tretze sueldos o de alli arriba en el millar» y haber mantenido el nivel de contribución expresado en el punto anterior, en el trienio previo a su designación para el cargo ${ }^{379}$. Escalas similares se aplicarían en el resto de las juderías aragonesas con categoría jurídica de ciudad y de parecida complexión económica, como Tarazona, Zaragoza o Huesca.

Gracias a un protocolo notarial datado en 1468 conocemos algo mejor el funcionamiento interno del sistema insaculatorio en una aljama prototípica como podía ser la oscense ${ }^{380}$. En correspondencia con la articulación social analizada, se agrupan los cargos electos en tres manos -la mayor, la mediana y la menor- representadas por otras tantas bolsitas, en cuyo interior se colocaban los teruelos o redolinos de los aspirantes que reunían las condiciones requeridas, y que el texto no aclara por contenerse, sin duda, en la reglamentación interna registrada en los pinkasim. Los cargos conscriptos se establecen del modo siguiente:

\begin{tabular}{|l|c|c|c|}
\hline Cargo & Mano mayor & Mano mediana & Mano Menor \\
\hline Adelantado & 7 & 7 & 7 \\
\hline Dayan & 6 & \multicolumn{3}{|c|}{$6^{381}$} \\
\hline Clavario & \multicolumn{3}{|c|}{10} \\
\hline Consejeros & 12 & $10^{382}$ & 23 \\
\hline Contadores & 10 & 11 & 15 \\
\hline Notarios & \multicolumn{4}{|c|}{10} \\
\hline Tasadores & 13 & 5 & 15 \\
\hline
\end{tabular}

No existe una total paridad en el cuerpo electoral, en atención al número de sus efectivos y al peso político-económico. Se aprecia un evidente equilibrio en los sectores sociales implicados en el adelantazgo y en los tasadores, mientras que la balanza se inclina favorablemente hacia la mano minor en lo referido a los consejeros, si atendemos al número de teruelos inmatriculados, no al de cargos operativos promovidos. Posiblemente el dayan se conforma en dos cuerpos electorales por componerse este dos magistrados, siempre y cuando corresponda elevar un sólo juez de ambas, lo que entraría en colisión con el precepto míshnico que entendía un mínimo constitutivo de tres personas ${ }^{383}$.

377 A.C.A., Real Cancillería, Reg. 2.189, fol. 155. Cit. Serrano y SANZ, Manuel, Orígenes de la dominación española en América, pág. LIII.

${ }_{378}$ Motis Dolader, Miguel Angel, «La socjedad judia aragonesa en la Edad Media», H/ Curso Historia Social de Aragón, Zaragoza, Institución Fernando el Católico, 1996, págs. 281-296.

379 A.C.A., Real Cancillería, Reg. 3642 , fol, 199v.

3*0 A.H.P.H. Protocolo núm. 23, Huesca, 1459, fol. 9.

381 La mano mediana y la menor forman circunscripción única.

$3 \$ 2$. Distrito único.

383 Mishna Sanhedrin, 2a.

Hispanta, LVU3, uim. 194 (1996) 885-944 
De la consulta de algunos documentos notariales se desprende que las irregularidades era frecuentes, al quitar o añadir inadvertidamente nombres en los teruelos, con manifiestos fraudes electorales ${ }^{384}$, extendidos también a otras demarcaciones ${ }^{385}$, lo que obligaba a la intervención real, que dictaba normas arbitrales y de contención de abusos, como sucediera con la aljama saguntina en 1390 a manos de Juan I ${ }^{386}$, reproducidas en 1403 con la reina doña María. El cuerpo electoral elevaba sus quejas aduciendo que habían sido postergadas algunas candidaturas para el adelantazgo, exigiendo que se cumpliera la legalidad vigente ${ }^{387}$.

Desde un punto de vista meramente constitucional, asistimos a una etapa de estabilidad, donde no se admitía que los dirigentes de las aljamas conculcaran derechos esenciales de sus administrados, como los títulos que cabían al recurso ante la instancia real ${ }^{388}$. Consonante con estos principios, se ocupará en 1480 de «fazer en aquella [la aljama de Zaragoza] algunos reparos e cosas necessarias al bien publico de aquella», dotándola de nuevas taqqanôt ${ }^{389}$, considerando intolerable la presunta ilegitimidad del proceso electoral, habiéndose detectado diversos fraudes «en los redolinos de los insaculados en los officios de la dicha aljama» ${ }^{390}$. Su mirada estaba puesta en la pacificación interna y en el aplacamiento de las luchas intestinas: «la voluntat nuestra es, zelantes el bien e reposo de la dicha aliama que el dicho reparo se faga e no se dilate porque no se de causa de mas malenconias entre los singulares de aquellas ${ }^{391}$.

384 Serrano Y Sanz, Manuel, Orígenes de la dominación española en América, pág. XVIII y Motis DOLADER, Miguel Angel, Los judíos en Aragón en la Edad Media (siglos XIII-XV), pág. 105.

385 En 1456, el procurador real dictará una resolución impugnando una elección por las irregularidades cometidas, exigiendo los redolins. Pons, Antonio, Los judios en el reino de Mallorca durante los siglos XIII y XIV, Palma de Mallorca, 1984, pág. 24.

386 A.C.A. Real Cancillería, 1898 , fols. 140-141. Vid. Hinojosa Montalvo, José, «Los judios del reino de Valencia durante el siglo Xv» pág. 152.

387 Hinojosa Montalvo, José, «Los judios del reino de Valencia durante el siglo xv», págs. 152-53.

388 En 1479, el soberano reprocha a los comisarios instituidos en la aljama de judios de la ciudad de Zaragoza que pretendían conculcar el derecho de apelación de sus administrados «a instancia de algunos judios singulares de aquella, poco zelantes el bien de la dicha aljama e singulares de aquella, seria stada fecha una ordinacion que ningun judio no se pueda quexar delante de nos o de nuestros officiales dellos, so grandes penas, assi pecuniarias como corporales, y en cara con excomunicacion judayca de que se sigue gran danyo e prejuicio a los singulares de aquella». A.C.A., Real Cancilleria, Reg. 3 562, fol. 18.

La documentación procedente de la Real Chancilleria de Valladolid, por ejemplo, pone de relieve que cabia a esta Corte el trámite de revisión de las sentencias dictadas por el ejuez mayor de los judíos» y, en su caso, la casación. VARONA, M.'. Antonia, «Pleitos judíos en la Real Chancillería de Valladolid. Regesta de sus cartas ejecutorias (1486-1495)", Sefarad, LIV (1994), págs. 155-193.

389 A.C.A., Real Cancillería, Reg, 3605 , fol. 73.

390 A.C.A., Real Cancillería, Reg. 3 562, fol. 18.

391 A.C.A., Real Cancillería, Reg. 3 562, fol. 37.

Hispania, LVI/3, núm. 194 (1996) 885-944 
Fernando II, llevado por los axiomas iusnaturalistas de la "pax" de la res publica, no se abstendrá de intervenir ${ }^{392}$ en la cada vez más débil autonomía interna de sus comunidades ${ }^{393}$. En Tortosa, nominará a los judíos susceptibles de acceder a los cargos, teniendo especial cuidado en que cerraran filas en torno a su política ${ }^{394}$. De forma paralela, las coaliciones de clanes familiares serán frenados, impidiendo que un padre y su hijo, un suegro y un yerno, o dos hermanos, entre otras posibles combinaciones de consanguíneos, ejerzan con simultaneidad funciones de secretarios, consejeros y tasadores, etc. ${ }^{395}$.

\section{EPÍlogo}

La dislocación que supone en el tejido social la conversión de las capas más instruidas y preparadas de la minoría judía aragonesa desde fines del siglo XIV y comienzos de la centuria siguiente, permite una mayor expansión del protagonismo social en las instancias de poder aljamial. Ello se traduce en una mayor hegemonía de las clases medias, un tanto relegadas hasta entonces por el sistema cooptativo que había entronizado determinados linajes en los puestos claves de la sociedad política. Si bien la insaculación no redimió en grado absoluto de los excesos y fraudes cometidos con anterioridad, sí permitió que paulatinamente se propendiera hacia el principio de representatividad y mayoría, así como la responsabilidad civil y penal de los electos.

El fortalecimiento del autoritarismo monárquico, si bien garantizó la estabilidad interna de las aljarnas, so pretexto de equilibrar las fuerzas centrífugas que la gangrenaban, permitió a los soberanos irrogarse determinadas prelaturas en el control y en la provisión de algunos puestos de confianza. La aceleración de un proceso de emulación osmótica de los principios gubernativos de la sociedad política cristiana -patente también en la "foralización" de aspectos del ordenamiento talmúdico que sería muy prolijo sistematizar aquí- permite con simultaneidad un recorte de la autonomía jurisdiccional, como se venía produciendo, por ejemplo, en gran parte de los principales concejos del Reino.

392 En recompensa por los servicios prestados por Vidal Astori, platero de Sagunto, encargado de cierta embajada en Portugal, es promovido al cargo de juez y rabino de todas las aljarnas del norte de Burgos. Bastarán, sin embargo, las protestas de Abraham Senior - juez supremo de todas las comunidades de Castilla y por tanto su superior jerárquico- para eclipsar tan fulgurante ascenso. BAER, Fritz, Die Juden im Christlichen Spanien. Erster Teil: Aragon und Navarra, vol. II, doc. 329.

393 KRJEGEL, Maurice, Les juifs à la fin du Moyen Age dans la Europe Mediterraneénne, pág. 61.

394 A.C.A., Real Cancilleria, Reg. 3 636, fols. $26 \mathrm{v}-27 \mathrm{v}$.

395 KRIEGEL, Maurice, Les juifs à la fin du Moyen Age dans la Europe Mediterraneénne, pág. 55.

Hispania, LVI/3, núm. 194 (1996) 885-944 